\title{
A privatização e descentralização do setor elétrico nacional frente à política ambiental brasilleira: Uma abordagem sociológica do caso das Pequenas Centrais Hidrelétricas (PCHs)
}

\section{PATRÍCIA APARECIDA PEREIRA SOUZA}

\begin{abstract}
Tese apresentada à Escola de Engenharia de São Carlos da Universidade de São Paulo, como parte dos requisitos para obtenção do título de Doutora em Ciências da Engenharia Ambiental.
\end{abstract}

ORIENTADORA: Profa. Dra. Norma Felicidade Lopes da Silva Valencio.

CO-ORIENTADOR: Prof. Dr. Frederico Fábio Mauad.

São Carlos 2004

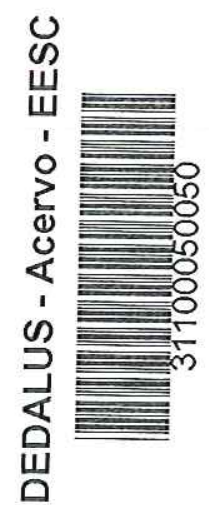




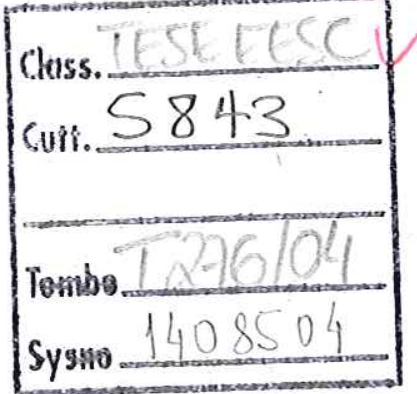

Ficha catalográfica preparada pela Seção de Tratamento da Informação do Serviço de Biblioteca - EESC/USP

Souza, Patrícia Aparecida Pereira

A privatização e descentralização do setor elétrico nacional frente à política ambiental brasileira : uma abordagem sociológica do caso das pequenas centrais hidrelétricas (PCHs) / Patrícia Aparecida Pereira de Souza. -- São Carlos, 2004.

Tese (Doutorado) -- Escola de Engenharia de São Carlos-Universidade de São Paulo, 2004.

Área: Ciências da Engenharia Ambiental.

Orientador: Profa. Dra. Norma Felicidade Lopes da Silva Valencio.

Co-Orientador: prof. Dr. Frederico Fábio Mauad.

1. PHC. 2. Meio ambiente e privatização no setor elétrico. I. Título. 


\section{FOLHA DE JULGAMENTO}

Candidato: Bacharel PATRICIA APARECIDA PEREIRA SOUZA

Tese defendida e julgada em 16-09-2004 perante a Comissão Julgadora:

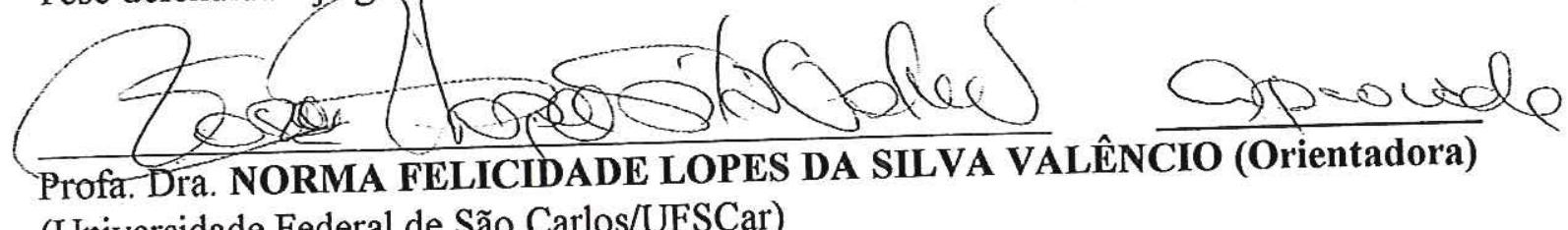
(Universidade Federal de São Carlos/UFSCar)

$\operatorname{ArOU} A D)$

Prof. Dr. MARCO ANTONIO VILLA

(Universidade Federal de São Carlos/UFSCar)

L 1 wanstoni

APROGADA

(Universidade Estadual de Campinas/UNICAMP)

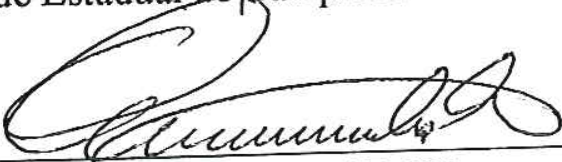

APROVADA

Prof. Associado WALDIR SCHALCH

(Escola de Engenharia de São Carlos/USP)

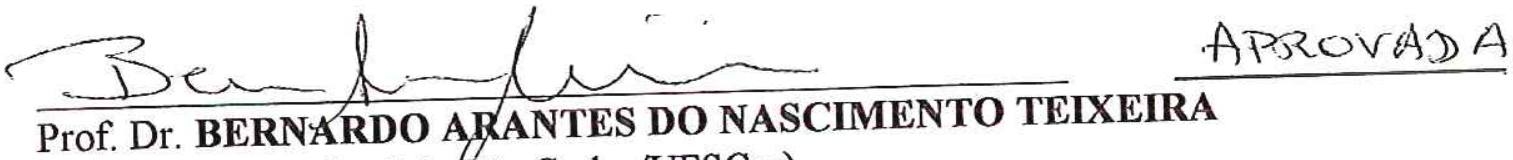

(Universidade Federal de São Carlos/UFSCar)

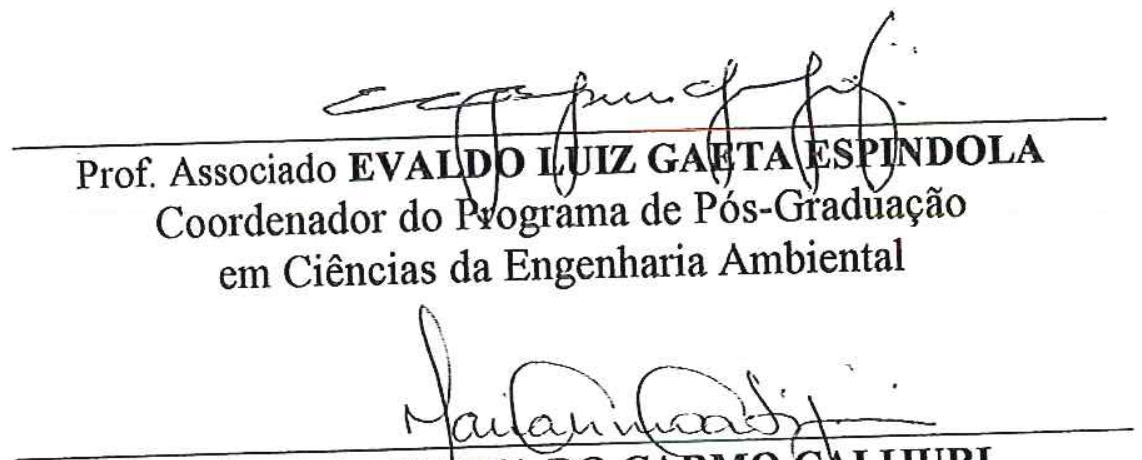

Profa. Titular MARIA DO CARMO CALIJURI

Presidente da Comissão de Pós-Graduação 
À toda minha família (Nã, mãe, pai, Lelo e Rô) e, em especial, à minha filha Ana Beat̂riz que tanto me inspira. 


\section{AGRADECIMENTOS}

À Deus, por nunca me deixar desistir, nem mesmo nos momentos difíceis.

A Professora Norma Felicidade Lopes da Silva Valencio, pela inestimável orientação durante a elaboração o balho.

Ao Professor Frederico Fábio Mauad, por ter me iniciado nos estudos das PCHs e por seu apoio e incentivo.

Ao CNPq pela bolsa concedida.

À minha família, pela confiança e apoio, principalmente, nesta fase final com os cuidados com a Bibi.

Ao meu marido Ernane, por seu companheirismo, ajuda, apoio e compreensão, crucial para o término do trabalho.

A todos os colegas, professores e funcionários do Departamento de Hidráulica e Saneamento e do Centro de Recursos Hídricos e Ecologia Aplicada (CRHEA).

Aos amigos pessoais, por sua pronta disposição em ajudar: Nilson, Cáscia, Camilinha,Conceição, Mércia, Evandro, Tiago, Agnaldo e Andréia. 


\section{SUMÁRIO}

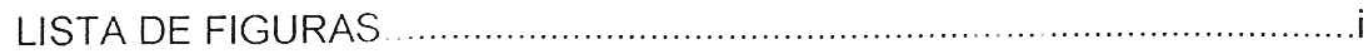

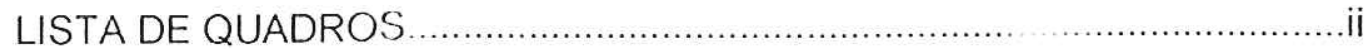

LISTA DE TABELAS ............................................................................

LISTA DE ABREVIATURAS E SIGLAS ..................................................iv

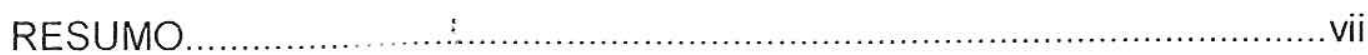

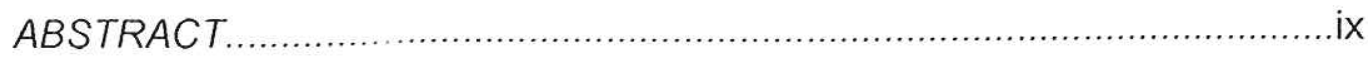

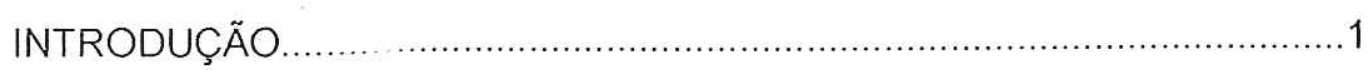

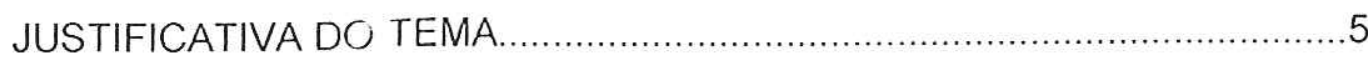

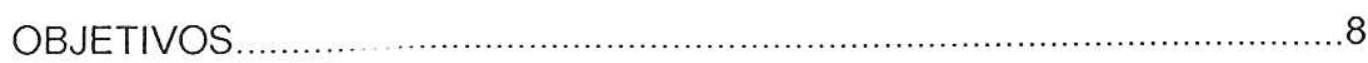

PROCEDIMENTOS METODOLÓGICOS ................................................11

CAPÍTULO 1: CEIIARIO POLÍTICO-INSTITUCIONAL DA PRIVATIZAÇÃO

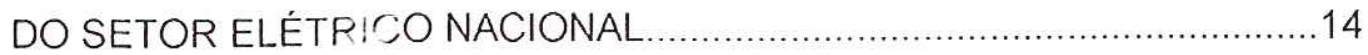

1.1. Histórico d) setor elétrico brasileiro..........................................17

1.2. Um novo ciclo de desenvolvimento incluindo as $\mathrm{PCHs..............22}$

CAPÍTULO 2: REESTRUTURAÇÃO DO SETOR ELÉTRICO: Uma breve descrição dos modı:los propostos

2.1. Descriçäc do $1^{\circ}$ Modelo Proposto..............................................34

2.2. Modelo de Setor Elétrico Proposto no Governo Lula...................39

2.3. Uma Aná se Crítica do Processo .............................................43 
CAPITULO 3: O MEIO AMBIENTE NA PAUTA DO PROCESSO DE TOMADA DE DECISÃO: O setor elétrico em perspectiva ..........................4 49

3.1. O ambientalismo: Do movimento alternativo à

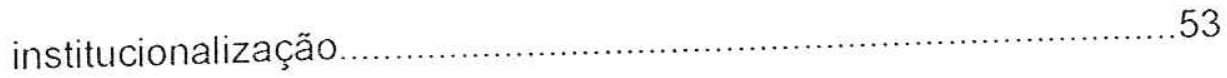

3.2. A introdução da questão ambiental na agenda do setor elétrico nacional

3.3. Gestão do meio ambiente $X$ Gestão de energia: Compatilidades e Incompatibilidades.

3.4. Limitações sócio-ambientais na implantação de PCHs. 69

CAPÍTULO 4: ALGUMAS DIMENSÕES DE SUSTENTABILIDADE APLICADAS ÀS PCHs: Uma breve descrição a partir de um estudo de caso .76

4.1. Antecedentes

4.2. Caracterização sócio-ambiental do local..................................79

4.3. Comitê de Bacia Hidrográfica...............................................93

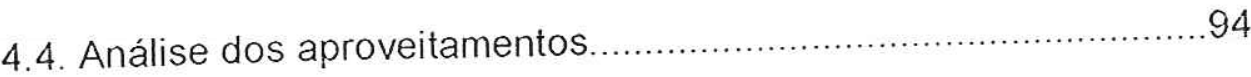

CONCLUSÃO 122

Sugestões para Estudos Futuros .125

BIBLIOGRAFIA 126 ANEXO 01 


\section{LISTA DE FIGURAS}

Figura 1: Localização dos aproveitamentos no trecho do rio Sapucaí. .......78

Figura 2: Principais vias de acesso aos empreedimentos. .80

Figura 3: Ilustração das estradas vicinais que cortam propriedades particulares .81

Figura 4: Perfil da bacia hidrográfica do rio Sapucai ..................................83

Figura 5: Paisagem dominante da região. 86

Figura 6: Trechos de mata ciliar intercalados com cultura, próximos ao rio Sapucaí. 86

Figura 7: Imagem digital do uso da terra e cobertura vegetal das usinas Retiro, Anhanguera e Palmeiras. 88

Figura 8: llustração de trechos com a queimada da cana 89

Figura 9: Ilustração de trechos da estrada vicinal, com a queimada da cana na margem direita, trechos de mata ciliar e o rio Sapucaí ao fundo. .90

Figura 10: Seção do rio Sapucaí com a área de inundação ilustrada. .99 


\section{LISTA DE QUADROS}

Quadro 1: Quadro Esquemático de Investigação. 10

Quadro 2: Principais componentes do processo de Avaliação de Impacto Ambiental (AIA)

Quadro 3: Breve caracterização dos principais aspectos da legislação brasileira sobre recursos hidricos. 102 
Tabela 1: Demografia dos Municipios de Guará e São Joaquim da Barra............. .92

Tabela 2: Descrição Geral dos Aproveitamentos - Ficha Técnica das Usinas. 96

Tabela 3: Impactos: Sócio-Ambientais referente aos très aproveitamentos. 98 
ACL: Ambiente de Contratação Livre.

ACR: Ambiente de Contratação Regulada.

AIA: Avaliação de Impacto Ambiental.

A.L.: América Latina.

ANEEL: Agência Nacional de Energia Elétrica.

Art: Artigo.

BNDES: Banco Nacional de Desenvolvimento Econômico e Social.

CCC: Conta Consumo de Combustiveis Fósseis.

CCEE: Câmara de Comercialização de Energia Elétrica.

CCMA: Comitê Consultivo de Meio Ambiente da Eletrobrás.

CEMIG: Companhia Energética de Minas Gerais.

CERJ: Companhia de Eletricidade do Estado do Rio de Janeiro.

CESP: Companhia Energética de São Paulo.

CETESB: Companhia de Tecnologia de Saneamento Ambiental, ligada à Secretaria do Meio Ambiente do governo de São Paulo.

CF: Constituição Federal.

CIESP: Centro das Indústrias do Estado de São Paulo.

CMMAD: Comissão Mundial sobre Meio Ambiente e Desenvolvimento.

CMSE: Comitê de Monitoramento do Setor Elétrico.

CNPE: Conselho Nacional de Politica Energética.

CNEC: Consórcio Nacional de Engenheiros Consultores.

CNUMAD: Conferência das Nações Unidas sobre Meio Ambiente e Desenvolvimento. 
COMASE: Comitê Coordenador de Atividades de Meio Ambiente do Setor Elétrico.

CONAMA: Conselho Nacional do Meio Ambiente.

CPFL: Companhia Paulista de Força e Luz.

CSPE: Comissão de Serviços Públicos de São Paulo.

DAIA: Departamento de Avaliação de Impacto Ambiental do Estado de São Paulo.

DBO: Demanda Bioquímica de Oxigênio.

DNAEE: Departamento Nacional de Águas e Energia Elétrica.

D.O: Diário Oficial.

DPA: Departamento Proteção Ambiental.

DS: Desenvolvimento Sustentável.

ECELSA: Companhia de Luz do Estado do Espírito Santo

EIA: Estudo de Impacto Ambiental.

ELETROBRÁS: Centrais Elétricas Brasileiras.

EPE: Empresa de Pesquisa Energética.

EUA: Estados Unidos da América.

FAPESP: Fundação de Amparo à Pesquisa do Estado de São Paulo.

FEPE: Fundação de Estudos de Planejamento Energético.

FIESP: Federação das Indústrias do Estado de São Paulo.

FINEP: Financiadora de Estudos e Projetos.

FMI: Fundo Monetário Internacional.

IAIA: International Association for Impact Assessment.

IQA: Índice de Qualidade das Águas.

LI: Licença de Instalação. 
LP: Licença Prévia.

MAE: Mercado Atacadista de Energia Elétrica.

MAIA: Manual de Avaliação de Impacto Ambiental.

MME: Ministério de Minas e Energia.

NEPA: National Environmental Policy Act.

OD: Oxigênio Dissolvido.

OIS: Operador Independente do Sistema.

ONG: Organização Não- Governamental.

ONS: Operador Nacional do Sistema.

ONU: Organização das Nações Unidas.

PCH: Pequena Central Hidrelétrica.

PCH-COM: Programa de Desenvolvimento e Comercialização de Energia de Pequenas Centrais Hidrelétricas.

PDMA: Plano Diretor para Proteção e Melhoria do Meio Ambiente.

PIE: Produtor Independente de Energia.

PNPCH: Programa Nacional de Pequenas Centrais Hidrelétricas.

PPS: Parcerias Público-Privadas.

PROINFA: Programa de Incentivo à Fontes Alternativas de Energia Elétrica.

RIMA: Relatório de Impacto Ambiental.

SEBAND: Sociedade Energética Bandeirantes.

SEMA: Secretaria Especial do Meio Ambiente.

SIN: Sistema Elétrico Interligado Nacional.

SINTREL: Sistema Integrado Nacional de Transmissão de Eletricidade.

SISNAMA: Sistema Nacional do Meio Ambiente

SMA: Secretaria do Meio Ambiente do Estado de São Paulo. 


\section{RESUMIO}

SOUZA.P.A.P. A privatização e descentralizaçäo do setor elétrico nacional frente à politica ambiental brasileira. Uma abordagem sociológica do caso das Pequenas Centrais Hidrelétricas (PCHs). São Carlos, 2004.170p. Tese (Doutorado)-Escola de Engenharia de São Carlos, Universidade de São Paulo.

A onda de recessão econômica e de desaceleração do crescimento da década de 80 , aliada à crise política e financeira vivenciada pelos Estados Nacionais na A.L., abriu terreno para que concepções neoliberais permeassem as decisões ligadas aos investimentos necessários em infraestrutura.

O Brasil, do Governo Collor ao FHC (1990 à 2002), seguiu esta orientação e, por meio dela, permitiu que vários segmentos dos serviços essenciais se tornassem passiveis de privatização e descentralização, dentre eles, o setor elétrico que foi reestruturado. Dado o contexto supra, este estudo visa analisar, sob um prisma sociológico e da geografia humana, o ressurgimento das pequenas centrais hidrelétricas no cenário nacional, intentando dar pistas da efetividade da política ambiental brasileira quando da implantação e recuperação destas usinas.

Trata-se de examinar quais mecanismos politico-institucionais permitem que o bem público, representado pelos recursos hídricos, possa ser apropriado para responder às necessidades de natureza privada, e como as necessidades sócio-ambientais imbricadas säo contempladas nesse processo. 
$\dot{E}$ apresentado um estudo de caso para trazer à tona, por um micro recorte, a implantação de pequenos aproveitamentos hidrelétricos no qual a necessidade expansionista do setor reitera um padrão de excludência social e pouca efetividade decisória dos agentes sociais afetados.

Palavras-chaves: PCH, meio ambiente e privatização do setor elétrico. 
SOUZA, P.A.P. The national electric sector privatization and decentralization in relation to the Brazilian environmental policy. A sociological approach of the Small Hydroelectric Power Plants case. São Carlos, 2004. 170p. Tese (Doutorado) - Escola de Engenharia de São Carlos, Universidade de São Paulo.

The 80's wave of economic recession and decelerated development, allied to political and financial crises experienced by Latin American National States, opened field to a spread-out of classic conceptions through decisions connected to necessary infra-structure investments.

Brazil followed this orientation, from Collor to FHC (1990 to 2002), and allowed many essential service segments to become liable of privatization and decentralization, among them, the electric sector, which was restructured. Considering this context, this study aims to analyze under sociological and human geographical viewpoints, the resurgence of Small Hydroelectric Power Plants on the national scenery, intending to give cues of the Brazilian environmental policy effectiveness, by the time of these plants implantation and recovery.

It concerns of examining which are the political-institutional mechanisms that allow the public welfare, represented by hydrous resources, to be convenient to private nature demands, and how the involved socialenvironmental demands are analyzed on this process.

A case study is presented in order to bring-up, through a short brief, the implantation of small hydroelectric plants, where the growing necessity of the 
sector, reaffirms a pattern of social exclusion and few conclusive effectiveness of the affected social agents.

Key-words: Small Hydroelectric Power Plants, Environment, Electric Sector Privatization. 
INTRODUÇÃO

A partir dos anos 90, com o governo Collor, a política econômica brasileira tem como uma de suas principais trocas a ampliação de espaço de atuação para o capital privado, passando este a exercer um papel maior no processo produtivo, cultural e de serviços, em particular, na área de energia.

Em termos práticos, buscou-se reorganizar as estruturas imbricadas na liberalização do comércio exterior e propiciar a abertura de oportunidades de investimento em setores estrangulados, sobretudo os que ainda persistiam sob controle estatal, os quais passaram por um amplo processo de descentralização e privatização, o que atingiu vários segmentos dos serviços essenciais, dentre os quais, o de energia. Este processo permitiu e, mesmo, fomentou - que as oportunidades de negócios atraissem capitais estrangeiros a fim de melhorar o perfil das contas nacionais frente aos requerimentos de equilibrio da mesma pelos organismos creditícios internacionais.

Ou seja, setores que, no passado, foram tidos como estratégicos para o desenvolvimento econômico do pais, tais como o de energia elétrica, tornaram-se passiveis de privatização e descentralização, podendo ser recortados e explorados por interesses privados em uma circunstância em que o Estado modificou sua compreensão acerca de suas funções macroeconômicas. 
O contexto supra coloca várias questões em termos de quão sustentável seria o novo modelo do segmento hidroenergético. Dentre quais, sobre o prisma da Sociologia do Desenvolvimento e Sociologia Ambiental, duas poderiam ser destacadas:

a) a abertura do ambiente de investimentos na hidroenergia a vários segmentos de produtores (empresas transnacionais, produtores privados, produtores independentes e autoprodutores de energia) - no lugar do produtor exclusivo de outrora, o estatal permitiu, pelo trânsito de capitais, a efetiva possibilidade do Estado alcançar seu propósito de ajuste fiscal tanto quanto equilibrar demanda e oferta de energia para crescimento do país?

b) houve ajustamento de objetivos e condutas pelos novos empreendedores do setor considerando os requerimentos da política ambiental?

O tema do acesso à água é, também, outro que gera inquietação. A garantia de disponibilidade do recurso hídrico para funções sociais, em geral, e disponibilização, em particular, para a produção elétrica, não pode ser dada pelo Estado. No muito, haveria sinalizações de que, em circunstância de escassez do recurso e disputa entre os multiusuários, essa demanda prevaleceria sobre as demais, o que nunca seria contrato escrito sobretudo por afrontar outros ditames estabelecidos constitucionalmente e reiterados pela Política Nacional de Recursos Hídricos (Lei Federal n. ${ }^{\circ} 9.433$ de 08/01/1997). Assim, 
como o Estado vai se posicionar frente às disputas de acesso desse bem de domínio público?

Em relação à primeira questão, a iniciativa privada embora tivesse recuperado a possibilidade de ser participe do setor, irá considerá-lo no seu rol de investimentos se dentro da lógica recorrente, ou seja, levando em conta a correspondência dos investimentos e seu retorno (Cotrim e Sato, 1995). Assim, se o setor élétrico, nas mãos do Estado, se obriga a prestar seus serviços com a maiór abrangência geográfica e social possível, nas mãos do setor privado, orienta-se exclusivamente pela intenção do lucro e, se possivel, maximizando-o no tempo, racionalidade esta que, minimamente, subjulga as dimensões sociais e ambientais de suas práticas.

Dai porque, se por um lado pequenas obras pareçam vir em contraponto (ao menos em intensidade de impactos) aos efeitos sócioambientais deletérios dos megaprojetos hidricos, por outro, ainda há controvérsias sobre a legitimidade de privatização do setor e acesso privilegiado aos recursos naturais, principalmente os hídricos (Valencio et al., 2000).

Dessa forma, a hipótese a ser considerada neste estudo será a de que a atual política do setor elétrico - caracterizada pela desestatização do setor e estímulo a novos investimentos privados, incluindo novas PCHs - se contrapõe aos objetivos de melhoria, preservação, e recuperação da qualidade sócio-ambiental - prescritos na Politica Nacional do Meio Ambiente (Lei Federal n. 6938/81) - posto, em tese, que a intensificação do 
uso capitalista do território (incluindo os recursos hidricos) ainda está inerentemente em contraposição ao ideário de sustentabilidade.

Mesmo sendo a hidroenergia um ingrediente essencial do "crescimento e desenvolvimento" - características irreversiveis da atualidade, alavancado que por indústrias, quer pelo setor de serviços, é de interesse deste trabalho identificar e analisar quais as expressões econômicas e sociais deste "desenvolvimento" que se constrói no nível local, o qual não só modifica ecossistemas aquáticos e terrestres envolventes - que acabam por reorientar novas formas, e nem por isso melhores, de produção social - mas reorganiza o território, incidindo sobre as circunstâncias futuras que envolverão a vida humana e econômica naquele espaço num recorte temporal significativamente largo. 
Com o retorno, a partir da década de 1990, da participação do investimento privado no setor elétrico brasileiro, tornou-se mais intensa a preocupação da sociedade com a potencialização do fenômeno a que Hardin (1968) convencionou chamar de "a tragédia dos comuns" e Berger (1994) de "dilema social, qual seja, o fato dos interesses privados dos concessionários não coincidirem com os interesses e necessidades dos vários segmentos sociais afetados por suas obras. Isso configura uma situação na qual o bem comum dificilmente é priorizado e, não raro, não é passivel de atendimento.

O reassentamento populacional, por exemplo, apesar de ser um dos componentes menos pesquisados na criação de lagos artificiais, ocorre com freqüência e é muito importante para o sucesso de projetos de construção de represas que criam lagos artificiais, intervindo, inclusive, em sua gestão futura. Mesmo quando o número total de pessoas a serem deslocadas for pequeno, o impacto das conseqüências do deslocamento para cada família individualmente afetada, é essencialmente o mesmo (Cernea, 1995).

Mesmo em uma circunstância em que a preocupação ambiental global tenha sido traduzida, no Brasil, em uma legislação comparativamente avançada, o Poder Público, via de regra, mostra-se incapaz de fazer com

\footnotetext{
1 Para elucidar a tragédia dos comuns, Garrett Hardin (1968) estudou a pastagem praticada pelo gado dos fazendeiros de uma comunidade. Se um fazendeiro decidisse aumentar um animal no pasto, a decisão teria como consequéncia positiva (o aumento de sua renda pela criação de mais um animal) e como consequência negativa (a escassez de pastagem), sendo a positiva exclusividade individual do fazendeiro, enquanto a negativa seria repartida
} 
que indivíduos e empresas cumpram-na, sobretudo porque ele próprio, quando à frente de megaempreendimentos, é um dos que mais recorrentemente a afronta. "O Estado é o maior violador de direitos humanos" é o que afirma, com razão, Bicudo et al. (2004).

Há estudos que, sob tal ou qual aspecto, têm se debruçado sobre os efeitos sócio-ambientais negativos provocados por megaempreendimentos hidrelétricos, como:

1. $\quad$ o deslocamento compulsório de populações humanas e a composição de novos atores que passam a deter o controle sobre o território, ressaltando a necessidade de questionamento da qualidade ambiental das formas produtivas que passam a ser instauradas pelos mesmos (Vainer, 1990);

2. a problemática dos impactos negativos, para as populações afetadas, numa circunstância em que não é mais possivel reverter o quadro de modificações da base biofísica onde se instaurava a sua reprodução social (Valencio et al., 1998; Rosa et al., 1988);

3. o conflito potencial básico entre produzir e utilizar energia e sua relação direta de causa e efeito com os problemas ambientais (Goldemberg, 1998);

4. a ampla variedade de problemas científicos, técnicos, tecnológicos, econômicos e sociais decorrentes da 
construção de reservatórios, além de os aproveitamentos resultantes do barramento dos rios serem catalisadores de inúmeras ações que se iniciam, em muitos casos, vários anos antes da sua construção, com trabalhos de planejamento, prognóstico, uso múltiplo e minimização de impactos (Tundisi, 1988), entre outros.

Escassa, porém, é a literatura que discorre e analisa tais efeitos em relação às PCHs, sendo referência Pacca (1996) e Tiago Filho (1999) e, desconhecida, aquela que se atém à uma interpretação sociológica desse tipo de intervenção territorial no contexto de privatização do setor elétrico brasileiro.

Das várias dimensões do problema, é preocupante as favorabilidades aos investidores privados interessados em recuperação e implantação de PCHs - dada as condições históricas favoráveis, os atrativos institucionais (SINTREL) e os novos dispositivos legais para autoprodutores e produtores independentes -, sem que se haja criado mecanismos eficientes para evitar os problemas sócio-ambientais recorrentes. Dito de outra forma, há uma expansão de investimentos em PCHs sobrepondo-se aos interesses locais já naquilo que concerne aos estímulos macropolíticos e aos dispositivos legais em que se assentam.

apud Berger, 1994). 
OBJETIVOS

\section{Objetivo Geral:}

O presente trabalho tem como objetivo analisar o processo de reestruturação do setor elétrico brasileiro, intentando caracterizar as tensões entre as premissas das políticas ambientais - da Política Nacional do Meio Ambiente (Lei Federal n. 6.938/81) e as da Política Nacional dos Recursos Hidricos (Lei Federal n. 9.433/97) - e os processos decisórios envolvendo a implantação e recuperação de $\mathrm{PCHs}$ na circunstância de privatização e descentralização do setor.

\section{Objetivos Específicos:}

Para tanto, serão descritos e analisados: o contexto políticoinstitucional da privatização do setor elétrico nacional, aspectos do contexto macroeconômico que apontem para o favorecimento aos novos agentes do setor elétrico, o ressurgimento das $\mathrm{PCHs}$ no cenário nacional e, por fim, a questão sócio-ambiental na agenda do setor elétrico nacional.

Um estudo de caso será apresentado ao final, apenas para trazer, por micro recortes, demonstração acerca da existência ou não:

- de integração efetiva das políticas públicas setoriais, principalmente a ambiental e a energética, caracterizando as dimensões de sustentabilidade ${ }^{2}$ imbricadas;

\footnotetext{
2 Das várias dimensöes de sustentabilidade que os mais diversos autores revelam - Sachs (1994); Ferreira (1996) entre outros - ao menos três já permitiram destacar a conflitividade
} 
- de integração do planejamento de uso dos recursos hídricos para fins hidrelétricos com os demais setores usuários e com o planejamento regional, estadual e nacional, sem dissociação dos aspectos de quantidade e qualidade:

- de integração da gestão privada e pública dos recursos hidricos, bem como a gestão do ambiente macroenvolvente (Quadro 1).

inerente que a poiitica de fomento de $\mathrm{PCHs}$, no processo como vem se constituindo, pode incitar, quais sejam:

1. A Sustentabilidade Sócio-Politica, a qual deve ser entendida por meio das variáveis democracia e equidade. Podendo inferir que a primeira deveria prover condições para o livre e pleno desenvolvimento das capacidades humanas essenciais (Bobbio et al. 1986).

$E$ equidade como situação na qual todos os individuos devem ter as mesmas oportunidades para se desenvolverem enquanto tais, garantida a solidariedade intra e intergeracional e a participação da sociedade envolvida como um todo.

2. A Sustentabilidade Ecológica que deve relacionar-se com a variável eficiência, ou seja, no reconhecimento da potencialidade e fragilidade ambiental da regiäo frente à especificidade da obra. A implementação de qualquer atividade em determinado território acaba por repercutir na dinàmica deste ecossistema e, no caso de PCHs, os riscos a que se tem que estar atento no binômio țipologia - localização são principalmente relacionados aos recursos hídricos, mais especificamente quantọ a sua disponibilidade em quantidade e qualidade satisfatória aos principais usos a que se pretende na região.

Inclusive porque, as hidrelétricas sendo vistas como empreendimentos que modificam o meio ambiente, devem imperiosamente serem consideradas num contexto de gestão integrada dos recursos hidricos, que preconiza a múltipla utilização, até porque a água é um elemento essencial para a manutenção da vida.

3. Por fim, a Sustentabilidade Cultural que remete aos valores culturais, sobretudo locais, que são passiveis de serem afetados, supondo-se que apenas por meio do estabelecimento de uma relação dialógica/comunicativa entre os diversos segmentos sociais envolvidos, buscando por soluções especificas a partir do instrumental cultural da população afetada e do seu entorno é que a implantação elou recuperação das PCHs passa parecer, sob tal dimensão sustentável. 
Quadro 1: Quadro Esquemático da Investigação.
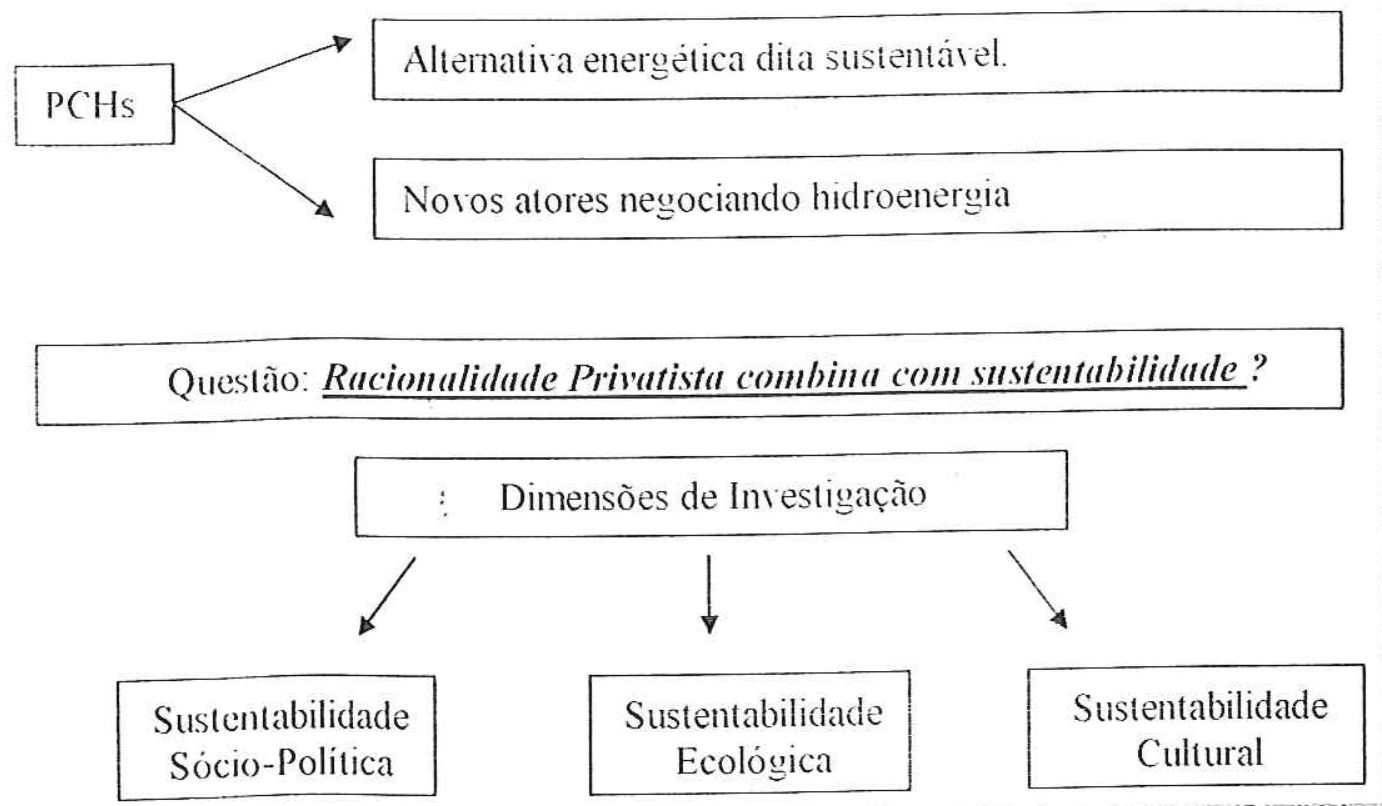

Para a efetivação deste trabalho, deve-se salientar a adoção de uma compreensão sociológica e da geografia humana na interpretação da alteração do marco regulatório do setor do elétrico, bem como do papel do Estado. 


\section{PROCEDIMENTOS METODOLÓGICOS}

A fim de analisar o processo de reestruturação do setor elétrico nacional, intentando das pistas, numa abordagem sociológica, de como as políticas energética e ambiental do pais correram não apenas em paralelo mas em conflito, valeu-se de três procedimentos, quais sejam:

a) Revisão de literatura nas áreas de sociologia e geografia humana privilegiadamente, com interfaces pontuais em economia, visando caracterizar sucintamente o contexto macrossocial e político-institucional onde seguem as Reformas de Estado no Brasil.

Dos referenciais teóricos mais destacados dessa interpretação estarão, dentre outros, Santos (1998), Moraes e Costa (1987) e Leff (1986, 2003).

Santos (1998) colabora naquilo que se refere à discussão da globalização como fator que falsifica, corrompe, desequilibra e destrói a unidade territorial; processo que, na fase atual, leva as sociedades a terminarem por adotar, de forma mais ou menos total, de maneira mais ou menos explicita, um modelo técnico único que se sobrepõe à multiplicidade de recursos naturais e humanos e que, além de promover a homogeneização das condições sócio-econômicas, acaba por acentuar e criar novas disparidades entre os países e regiões. As recentes reformas estruturais propostas pelo Banco Mundial aos países em desenvolvimento, como um modelo único, não consideram adequadamente as especificidades 
nacionais e incitam o tipo de fenômeno social propenso a gerar imensos impactos sócio-ambientais no nivel local.

Nos referencia Moraes e Costa (1987), principalmente, naquilo que remetem à análise dos problemas ambientais e suas imbricações na ordem democrática e na forma de apropriação do território e seus recursos, onde a ocupação dos espaços comandada pelo capital, isto é, orientada segundo seus interesses, privilegia os espaços de produção em detrimento do espaço de vivência. O resultado mais visivel aparece em duas contradições: a exaustão relativa dos recursos naturais e a degradação ambiental. Tais autores, ainda colaboram no entendimento da tessitura entre políticas territoriais e soberania de populações e nações. Essa reflexão é ainda mais oportuna em vista do risco de escassez de energia em razão da demanda veloz e reprimida, a qual pode acarretar um retrocesso dos direitos sociais e ambientais, os quais poderão ser deixados à parte na tomada de decisão do setor.

Por fim, Leff $(1986,2003)$, por nos introduzir a uma perspectiva histórico-ecológica do desenvolvimento, bem com por vincular um enfoque ecológico das lutas sociais, as quais acabam por ser o veiculo para a "internalização das externalidades negativas"; ou seja, permite analisar como a sociedade consegue, pela cultura e mobilização, fazer com que custos ecológicos apareçam na contabilidade das atividades quando estas são assumidas como conceito politicamente situado (muito diferente do ecologismo burocrático internacional). Isto é, a escassez ecológica não é determinada exclusivamente por condiçöes naturais. Seria, segundo Leff, 
muito mais pelas formas vigentes de apropriação social e exploração econômica da natureza e pelas condições políticas de inserção dos atores inseridos no processo de economização do mundo.

b) Em seguida, realizou-se pesquisa documental sintetizando, de um lado, a legislação ambiental e do setor elétrico e documentos afins no que de pertinente havia para caracterizar o marco regulatório, de outro, caracterizando sócio-ambientalmente a área de investigação de campo, sendo as principais fontes utilizadas o Plano de Bacia e os relatórios da CPFL. (Anexo 01).

c) E, por fim, foi feita uma pesquisa de campo utilizando-se, como ferramentas qualitativas, a fotodocumentação e entrevistas com representantes dos grupos envolvidos e cidadãos do lugar. O propósito foi confrotar o discurso local com a discussão anterior a cerca das tensões do setor elétrico com aspectos ambientais, sócio-politicos e culturais, os quais deveriam ser melhor contemplados no processo decisório de implantação dos empreendimentos. 


\section{1 - CENÁRIO POLÍtiCO-INSTITUCIONAL DA PRIVATIZAÇÃo DO SETOR ELÉTRICO NACIONAL}

Seguindo as recomendações de caráter neoliberal, a política econômica brasileira da década de 90 apresentou, como uma das suas principais características, uma opção pela ampliação do espaço de atuação para o capital privado.

No período de 1994 à 2002 - correspondente aos governos FHC I e II - marcado e orientado por relações internacionais mundializadas -, temas como o da privatização foram discutidos abertamente apenas no "establishment" e tornaram-se base para reformas significativas dos padrões nacionais de produção e consumo.

Em termos das referências mundializadas, não há como deixar de reconhecer a importância, como fundamento da prática do Estado, do que denominou-se de Consenso de Washington ${ }^{3}$, o qual aspirou, entre outros, que três planos de ação entrassem em curso nas economias emergentes, como o Brasil, a saber:

i) o de ordem macroeconômica, passando o Estado a comprometer-se com um rigoroso equilíbrio fiscal, com

\footnotetext{
${ }^{3}$ Reunião sediada em Washington, pois lá funciona o International Institute for Economy, onde intelectuais pensando na perspectiva do poder, promovem uma reunião cujo objetivo era discutir as reformas necessárias para que a América Latina saisse da década que alguns chamaram de década perdida, da estagnaçäo, da inflação, da recessão, da divida
} 
reformas administrativas, previdenciárias, fiscais e um corte violento no gasto público, com o intuito de estabilização monetária;

ii) o de ordem microeconômica, que levasse o capital à circunstância de desoneração fiscal, cujo desiderato seria a ampliação da competitividade de bens e serviços no mercado internacional (partindo do princípio de que este atuaria de forma desregúlada, isto é, aberta) e, por fim;

iii) o das reformas estruturais, que perpassam a desregulação do mercado, a privatização em segmentos tradicionalmente estatizados, o fortalecimento de garantias do direito de propriedade, sobretudo na zona de fronteira, dentre outros.

A implementação dos três planos supra, de maneira integrada, foi sinalizado pelos teóricos e políticos que formavam o referido Consenso como sendo um caminho necessário para a renegociação da dívida externa e/ou "conditio" para se conseguir novos empréstimos junto ao sistema financeiro internacional. Isto é, agiram como fatores exógenos que buscaram a concordância do Estado a partir do evidenciamento de suas suscetibilidades; e, assim agindo, tais procedimentos foram tratados como única forma possível para os males das economias emergentes, na conquista da confiança dos mercados internacionais. (Fiori, 1996).

externa e retomasse o caminho do crescimento, do aumento da riqueza, do desenvolvimento e, quem sabe, da igualdade (Fiori, 1996). 
Brasil seguiu esta orientação e, por meio dela, setores que, no passado, foram tidos como estratégicos para o desenvolvimento econômico do pais, tais como o de energia elétrica, tornaram-se passiveis de privatização e descentralização. Disso resultou na sua abertura para o interesse de empresas transnacionais, produtores privados, produtores independentes e autoprodutores de energia.

Assim, setores como o da hidroenergia, que não perderam sua importância no processo de ampliação das possibilidades econômicas e sociais $^{4}$, e que estavam sob a competência da União - explorando, diretamente ou mediante autorização, concessão ou permissão os serviços e instalações de energia elétrica e o aproveitamento energético dos cursos de água, em articulação com os Estados onde se situavam os potenciais hidroenergéticos (alinia $b$ do inciso XII do Art. 21 da CF) - passaram ao dominio dos interesses privados em uma circunstância em que o Estado também modifica sua compreensão acerca de suas funções econômicas e numa atuação que adota estratégias de curto prazo e instrumentais - tenta reduzir despesas a fim de garantir o cumprimento do ajuste fiscal a que se comprometeu junto ao FMI.

Ou seja, o que é apresentado à sociedade civil como um novo modelo implementado para o setor elétrico nada mais é que a criação de condições para a viabilização de outras transações econômicas do Estado com o mercado, deixando à lógica e praxis deste último a incumbência de inspirar o redesenho do papel do Estado. 
Contudo, um dos paradoxos do Consenso de Washington reside justamente no fato de que, embora reconheça que a escolna da forma de implementação de politicas públicas dependa de contextos especificos de cada periodo e de cada país, acaba tornando-se um "modelo ótimo de implementação", aplicável a qualquer caso. Enfim, do pensamento único, que torna-se em prática única, a caracteristica autoritária revestida nessa modernidade.

\section{1 - Histórico do Setor Elétrico Brasileiro}

Historicamente, o desenvolvimento industrial brasileiro esteve atrelado ao desenvolvimento das centrais hidrelétricas, particularmente as de pequeno porte, ou seja, as pequenas centrais hidrelétricas, também conhecidas pela sigla PCHs, graças à iniciativa de autoprodutores e de empresas de serviço público de caráter local, privadas ou municipais, além de capital estrangeiro envolvido ${ }^{5}$.

Sucessivamente, de maneira descentralizada, dado o seu grande potencial hidráulico, o Brasil viu crescer o seu parque gerador, quase que totalmente baseado nos recursos hídricos. Pouco a pouco, as potências instaladas foram aumentando, sobrepondo-se, às vezes, às necessidades do proprietário, o qual acabava instalando pequenas redes de distribuição,

\footnotetext{
${ }^{4}$ Entendendo que o acesso à energia pode ser entendido como uma dimensão material dos direitos de cidadania.

${ }^{5}$ No Brasil, a entrada da hidreletricidade deu-se no ano de 1883 , com a implantação da central hidrelétrica do Ribeirão do Inferno, na bacia do Jequitinhonha, municipio de Diamantina, na então provincia de MG. Mas só em1889, as vésperas da Proclamação da República, inaugurou-se a primeira usina hidrelétrica pertencente ao serviço público do Brasil. marcando o término de experièncias isoladas, com a construção da Usina de Marmelos, em Juiz de Fora, MG (Centro da Memória da Eletricidade no Brasil, 1989; Gomes, 1986)
} 
as quais foram se expandindo gradativamente às regiões vizinhas, surgindo a possibilıdade de uma maior rentabilidade do investimento da usina, à medida quie foram aumentando a potência das mesmas e fornecendo eletricidarle às populações das áreas ao derredor onde estavam sendo desenvolvidas atividades produtivas ou sociais (Mariotoni e Mauad, 1999).

Conludo, a partir de 1930/40, com o fortalecimento do processo de industrialı/ação do país - consolidado na década de 1950 - e as vantagens de economia de escala, o Estado, no papel de indutor do crescimento económı.() em setores tido como estratégicos, optou pela construção de grandes centrais hidrelétricas e a formação de sistemas elétricos integrad(n:: O mercado de equipamento e serviços para pequenas centrais entrou, com isso, em recessão, provocando a retração de indústrias e empresa'; de engenharia especializadas e, por falta de apoio, de assistência técnica ": de peças de reposição a, maioria das pequenas usinas instaladas foram sindo, pouco a pouco, desativadas (Lourenção e Lima, 2000).

Na década de 1950, com a construção de centrais elétricas estaduais em Minn: Gerais, São Paulo e Rio Grande do Sul, o país entrou num ciclo de desunvolvimento acelerado. A força política das companhias de eletricidide estaduais foi se ampliando, e passaram a gerenciar seus próprios; projetos e construções das grandes centrais hidrelétricas, ainda que em hacias de integração nacional.

O viés fortemente estatizante e centralizador do modelo econômico prevaler,ente no período supra não contrariou a expansão dos investimentos estaduals; ao contrário, pode-se dizer que foram políticas com alto grau de 
complementariedade. Entretanto, a concentração das atividades de eletrificação, quando nas mãos das grandes companhias estaduais, não permitiu complementariedade com as Pequenas Centrais Hidrelétricas, mas levou-as à extinção, quando não à absorção pura e simples, para o atendimento, em nivel regional, onde não se vislumbrava ganhos de escala. Daí porque o surgimento das grandes companhias energéticas estaduais que, em parceira com a "holding" formada pela ELETROBRÁS ${ }^{6}$ e suas controladas, denotaram formas de ação características de regime de monopólio, com as tarifas fortemente monitoradas pelo governo federal, que fazia disso um dos mecanismos de controle da inflação.

O resultado foi que o Brasil, que chegou a contar com mais de mil e oitocentas PCHs, gerando em torno de $1110 \mathrm{MW}$, passou por um processo de desativação da geração descentralizada, resultando, até a década de 80 , no abandono de mais de 1400 centrais de pequeno porte (Tiago Filho, 1999).

As crises do petróleo, da década de 1970, foram as circunstâncias exógenas que incitaram o lançamento, em 1984, do Programa Nacional de Pequenas Centrais Hidrelétricas, PNPCH, que tinha como objetivo o desenvolvimento de uma tecnologia nacional que viabilizasse um novo ciclo de implantação das pequenas centrais, bem como o incremento e a

\footnotetext{
${ }^{6}$ Centrais Elétricas Brasileiras S.A., criada pela Lei $n .{ }^{0} 3.890$, de Abril de 1961, como empresa estatal de ámbito nacional, para coordenar as atividades de planejamento, financiamento e execuçăo da politica da energia elétrica no Brasil.
} 
modernização da indústria nacional de componentes e de equipamentos de geração hidrelétrica, com tecnologia adequada aos pequenos potenciais ${ }^{7}$.

O programa, que tinha o objetivo de incentivar a participação do setor privado, conseguiu apenas motivar algumas pequenas concessionárias, normalmente localizadas nas novas fronteiras agro-econômicas, onde a implantação das PCHs não era encarada apenas um negócio e, sim, como um agente de desenvolvimento econômico-social. A intervenção do Estado na economia ainda era forte e o controle das tarifas continuou sendo usado como mecanismo de controle inflacionário. O programa não vislumbrou o retorno esperado da operação de geração de energia num contexto de vulnerabilidade da política monetária e da falta de garantia de recursos. Isto é, falta de uma política crediticia estável para novos investidores e juros atrativos, ficando restrito a, apenas, algumas ações isoladas, mas nada que abrangesse o território nacional (Tiago Filho, 1999).

Ao final da década de 1980 e início da década de 1990, rápidas mudanças políticas e econômicas ocorridas no cenário mundial começam a influir no cenário nacional. Já a produção de bens e serviços não podia ficar ao largo da globalização da economia e da privatização de empresas em setores que, historicamente, estavam em mãos estatais. Para o governo federal acreditava-se, então, ser de fundamental importância a reformulação, dentre outros, do setor elétrico nacional para a expansão da

\footnotetext{
7 Por intermédio desse programa, houve açöes importantes como: a elaboração dos Manuais de Pequenas, Mini e Microcentrais, a construção dos Laboratórios Hidromecânico e Eletromecânico na Escola Federal de Engenharia de Itajubá e a edição de nove Cursos de Estudos, Projetos e Construção de Pequenas Centrais Hidrelétricas, ministrados pela EFEI, em parceria com a ELETROBRÁS (Tiago Filho, 1999).
} 
oferta da eletricidade - e dos novos investimentos dele dependentes inviabilizada pela crise financeira da União e dos estados da federação.

O Brasil seguiu esta orientação e, por meio dela, vários setores tornaram-se passiveis de privatização e descentralização e, disso, resultou na abertura do setor elétrico para o interesse de empresas transnacionais, produtores privados, produtores independentes e autoprodutores de energia.

A reestruturação do setor elétrico e do papel do Estado - passando de investidor para financiador (via BNDES), fiscalizador e poder concedente -, aliada a falta de compasso entre a demanda por eletricidade e os investimentos em grandes hidrelétricas, exige que o Ministério de Minas e Energia (MME) pense novas formas de atuação para garantir condições de reentrada da iniciativa privada no setor, através do investimento em novas unidades geradoras, propiciando a expansão da oferta de energia de forma mais rápida e eficiente.

O fato foi que o MME não teve as condiçőes políticas suficientes para viabilizá-lo e a crise do setor, pela qual passariam os brasileiros a conviver explicitamente entre os anos de 2001 e 2002, deixou claro que outras forças políticas foram convocadas a tomar o papel deste Ministério para contornar os efeitos dos investimentos estatais retardatários ou dos investimentos privados não seduzidos pelas estratégias de atração adotadas até então.

Logo, a crise pela qual passa o setor elétrico não se trata de uma crise de fontes de recursos naturais (em que a responsabilidade de "São Pedro" foi, também, mencionada pelas autoridades que tomaram a interlocução 
com a sociedade), mas de uma crise cujas origens apontam, por um lado, o problema estrutural da economia brasileira e, por outro, o da vulnerabilidade política a que a sociedade está exposta. Se períodos hidrológicos desfavoráveis houve, apesar de previsiveis - o ressurgimento, no cenário nacional, das pequenas centrais hidrelétricas ${ }^{3}(\mathrm{PCHs})$, deveu-se ao esforço intensivo em explicitar, ao capital privado, a rede de proteção estatal com a qual poderia vir a contar num longo prazo.

\section{2 - Um novo ciclo de desenvolvimento incluindo as PCHs}

A reformulação e as estratégias para a ampliação dos investimentos no setor elétrico nacional - caracterizada, sobretudo, por um novo marco regulatório e a transformação do papel do Estado, de investidor para fiscalizador e poder concedente -, têm a peculiaridade de interpretar que a capacidade de alavancagem da geração não está apenas através de megaobras de geração de energia mas, também, através de unidades geradoras alternativas, como as PCHs, por meio do o Programa de Incentivo à Fontes Alternativas de Energia Elétrica (Proinfa) ${ }^{9}$, criado pela Lei Federal n. ${ }^{\circ} 10.438$, de 26 de Abril de 2002 e regulamentado pelo Decreto n. ${ }^{\circ} 4.541$, de 23 de Dezembro de 2002.

\footnotetext{
${ }^{3}$ De acordo com a Resolução 394 da ANEEL de 04/12/1998 fica definida como PCH as usinas com 1.000 a $30.000 \mathrm{~kW}$ de potência instalada e área total do reservatório igual ou inferior a $3,0 \mathrm{~km}^{2 n}$. O parágrafo único considera como área do reservatório a "delimitada pela cota d'água associada à vazão de cheia com tempo de recorrência de 100 anos".

Criado no âmbito do Ministério de Minas e Energia - MME -, o programa tem como objetivo a diversificação da matriz energética brasileira e a busca de soluções de cunho regional com a utilização de fontes renováveis de energia, mediante o aproveitamento econômico de insumos disponiveis e das tecnologias aplicáveis, a partir do aumento da participação de energia elétrica produzida com base nas fontes eólica, pequenas centrais hidrelètricas e biomassa, no Sistema Elétrico Interligado Nacional - SIN.
} 
A princípio, o demandante comum de eletricidade, sofredor da crise recente, pode não conceber a importância de $\mathrm{PCH}$ na resolução de seu problema de abastecimento. Acostumou-se à expectativa de ser provido pelas megaobras. Todavia, a possibilidade de venda de excedentes de todos os produtores interligados no sistema, propiciou vislumbrar que a pequena obra em alguns lugares fosse tão importante quanto o mega empreendimento, com anos à frente para finalizar obras civis e gerar alguma energia. Aliás, a pequena obra, nisso, passou a constituir vantagem no contexto de crise já instaurada: havia ausência de alternativas de abastecimento para uma demanda reprimida e o prazo de maturação mais curto dos investimentos em PCHs podia ser a solução para que o ajuste sofrido do comportamento do consumidor (com todas as sanções financeiras e terrorismo psicológico com as ameaças de corte de suprimento) fosse apenas conjuntural ${ }^{10}$.

Aliado a isso, após o apagão de $2001^{11}$, a eficiência energética passou a ser um lema para os mais diversos setores produtivos do pais, principalmente para o setor eletrointensivo, no qual figuram as empresas

\footnotetext{
${ }^{10}$ Para Mário Santos, presidente da ONS (Operador Nacional do Sistema), o risco de escassez de energia elétrica em futuro próximo é minimo. Considerando apenas as obras em andamento e os novos empreendimentos concedidos, o acréscimo na oferta de energia elétrica deverá totalizar 12.885 MW no período 2003/2007, com uma taxa média anual de crescimento de $5,5 \%$ - o que permite uma situação tranquila com niveis médios de chuva. Para Santos, os riscos de racionamento só superam $5 \%$ a partir de 2007 , ano em que a previsão de conclusão de obras de geração de energia está limitada a 73 MW (Revista Notícias - FIESP/CIESP, 2003).

"A Medida Provisória n 2.198-5, de 24 de Agosto de 2001, cria e instala a Câmara de Gestão da Crise de Energia Elétrica, do Conselho do Governo, estabelecendo diretrizes para programas de enfrentamento da crise de energia elétrica, com o objetivo de propor e implementar medidas de natureza emergencial para compatibilizar demanda e oferta de energia elétrica, de forma a evitar interrupçőes intempestivas ou imprevistas do suprimento de energia elétrica.
} 


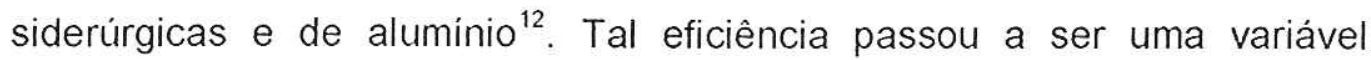
estratégica na cartilha de sobrevivência desses produtores em particular, afim de terem assegurado o fornecimento de energia de longo prazo, com qualidade e preços competitivos, que é um incentivo a mais à autogeração ${ }^{13}$.

Alega-se que as PCHs, em função de diversas circunstâncias (operacionais, ambientais, de economia de combustivel escasso e de custos de investimentos) e, também, em razão dos atrativos institucionais a essa participação, tais como a implantação do o SINTREL (Sistema Integrado Nacional de Transmissão de Eletricidade) - criado pelo Governo Federal, em 1993, com o objetivo de assegurar acesso integrado aos sistemas de transmissão, viabilizando a competição na geração, distribuição e comercialização de energia - podem se apresentar como a alternativa mais conveniente e atraente, tanto do ponto de vista do investidor como do ponto de vista de interesses nacionais ${ }^{14}$.

12 De acordo com dados da Associação Brasileira do Aluminio (Abal), em 2001, 13\% da energia consumida pelo setor vinha da geração própria. A associação estima que, até 2006 , esse percentual salte para $50 \%$, com um investimento estimado em US\$ 1,5 bilhão. O objetivo é livrar-se dos efeitos de um novo racionamento bem como de eventuais aumentos de preços, reduzindo o impacto do item eletricidade no custo final da produção. (Wiegratz, 2003).

${ }^{13}$ Apenas nas bacias dos Rios Tocantins e Araguaia, na Região Norte, há 14 usinas sendo construidas por companhias do setor de aluminio que, juntamente a outros investimentos em auto-suficiência energética espalhados no pais, ampliarão o percentual de autogeração dos atuais $12 \%$ para mais de $50 \%$ nos próximos anos. O seu interesse pela economia energética é bastante compreensivel, pois a produção de alumínio primário tem sido um dos processos eletrointensivos mais penalizados com a escassez de energia com a qual os brasileiros estão convivendo pelo menos desde o começo dos anos 90 . Outra vantagem, é a de fugir dos preços salgados cobrados pelas concessionárias de energia elétrica. $\mathrm{Na}$ Valesul, controlada pela Companhia Vale do Rio Doce e sediada no Rio de Janeiro, o custo do $M W h$ produzido por seu sistema de autogeração é de $R \$ 28$, enquanto que o valor pago à Light é de R\$75 - uma economia de 167\%. (Eficiência Energética, 2003).

${ }^{14}$ Do ponto de vista do investidor privado, sua decisão de construir ou recuperar uma $\mathrm{PCH}$ decorrerá, via de regra, de um atrativo econômico financeiro (custos) ou da absoluta impossibilidade de abastecimento de energia elétrica a partir de outra alternativa e, do 
A outorga para o empreendimento sem necessidade de licitação; a isenção de pagamento da taxa de compensação financeira aos Estados e Municipios; a possibilidade de comercializar de imediato a energia produzida com consumidores cuja carga seja maior ou igual a $500 \mathrm{~kW}$; e a isenção de pagamento por uso das redes de transmissão e distribuição para PCHs que entrarem em operação até o ano de 2003, com redução de no mínimo $50 \%$ deste custo para as que entrarem após esta data ${ }^{15}$ (Eletrobrás, 2001) são aspectos que clarificam a asserção supra, isto é, de estrutura e dinâmica de um novo mercado.

O favorecimento conjuntural também contaria com o incentivo adicional da Eletrobrás - em parceria com o BNDES (Banco Nacional de Desenvolvimento Econômico e Social) e em consonância com os esforços do MME, de modo a ampliar as condições de viabilização desses empreendimentos - através do Programa de Desenvolvimento e Comercialização de Energia de Pequenas Centrais Hidrelétricas (PCHCOM), cujo objetivo é viabilizar a implantação e/ou a revitalização de PCHs conectadas ao sistema interligado brasileiro. Nele, a Eletrobrás faz o acompanhamento da instalação, da operação e da manutenção da usina; garante a qualidade do projeto em relação à engenharia e ao meio ambiente

ponto de vista dos interesses nacionais, no maior aporte de energia ao sistema (Cotrim e Sato, 1995).

${ }^{15}$ Nessa nova configuração, e com a crise energética deflagrada, retoma-se então o Programa Nacional de Pequenas Centrais Hidrelétricas (PNPCH), aprovado pelo governo brasileiro no inicio de 1984, para que a construção ou mesmo recuperação de uma PCH se constitua uma alternativa para atendimento local das necessidades de energia elétrica, especialmente em micro-regiões não alcançadas pelos sistemas de transmissão ou de subtransmissão das concessionárias de serviço público de eletricidade ou, ainda, pela falta de energia em regiões em desenvolvimento e perspectivas de escassez de energia elétrica para as áreas atualmente atendidas porém com consumo em expansão. 
e apresenta o BNDES como fonte possivel de financiamento para o empreendimento (Eletrobrás, 2001).

Ademais, caso sejam implantadas no sistema isolado da Região Norte, podem também receber incentivo do Fundo formado com recursos da Conta Consumo de Combustiveis Fósseis (CCC), para financiar os empreendimentos, caso substituam geradoras térmicas a óleo diesel nos sistemas isolados da Região Norte ${ }^{16}$.

Daí porque, se de um lado, a liderança desse segmento nos empreendimentos em autogeração ser uma prática econômica relevante tanto para a mitigação da crise da oferta quanto para atestar a capacidade criativa do empresariado - uma resiliência ${ }^{17}$, por assim, dizer, apreciável e corroborativa do paradigma norteador dos gestores públicos, à medida em que, sob o principio fundamentador da autoprodução, deixar-se-ia de consumir a energia do sistema geral e este ganharia uma folga.

Por outro, esse segmento já suficientemente capitalizado e concentrado, passa a arrogar desde o seu lugar de poder econômico o direito a apropriação dos benefícios da autoprodução que alocam dinheiro

16 A resolução da Aneel $n^{\circ} 245 / 1999$ prevê que todas as pequenas hidrelétricas, com potência entre 1 e $30 \mathrm{MW}$, que forem implantadas em sistemas elétricos isolados em. substituição à usinas termelétricas que usam derivados de petróleo para geração de energia, terão direito a receber a CCC. Com isso, a Aneel quer incentivar a construção, nos sistemas isolados, de novas PCHs ou de empreendimentos de geração que façam uso de recursos naturais renováveis. Atualmente, duas das $11 \mathrm{PCH}$ 's que tem direito à CCC estão em operação: Monte Belo (4 MW) e Altoé II (1,1 MW), ambas em Rondônia.( http://wmw.infoenergia.com.br)

17 Para a ecologia, qualquer ecossistema está sujeito constantemente a desarranjos perturbando os mesmos. Estas perturbações, de acordo com a intensidade, podem ser "absorvidas" pelo ecossistem̄a sem que haja grandes danos para o mesmo. A esta constância dentro de um, écossistema, mantida por forças internas denomina-se equilibrio ecológico. As forças internas são resultantes das complexas relações entre organismos e meio físico. Já a capacidade de resposta de um ecossistema a perturbações é chamada 
público para a iniciativa privada. E a busca por tais ganhos - ou seja, a disputa por recursos públicos escassos - impede que as iniciativas de empreendedores jovens, pequenos coletivos de dada localidade, não articulados a outros ramos da atividade, dentre outros tenham a elegibilidade devida, na frente ou, sobretudo, nas decisões de bastidores. Apaziguar os fortes antes de fortalecer os fracos é a medida engedrada no fomento às PCHs. E nisso, então, a sustentabilidade social destas políticas é nula ${ }^{18}$.

Considerando o período 1998-2002, o número de usinas hidrelétricas licitadas pela Aneel, desde o início de suas atividades (1998), alcança um total de 50, sendo que 18 destas usinas envolvem a participação de empresas industriais eletrointensivas, que se caracterizam por serem intensivas no consumo energético como: alumínio, ferroligas, cimento, siderurgia, papel e celulose, e em menor medida os produtos químicos. Tratam-se, portanto, de processos produtivos que consomem energia de

resiliência, ou seja, é a capacidade de regeneração a partir da sua dinâmica interna. (http:/leducar.sc.usp.br)

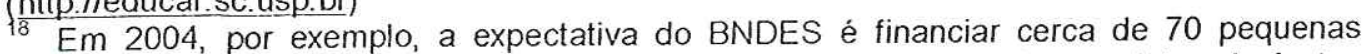
usinas. O banco vai priorizar em 2004, na área de energia, o apoio a projetos de fontes alternativas, como as Pequenas Centrais Hidrelétricas (PCHs). No momento, segundo o superintendente da área no BNDES, Nélson Siffert, o banco estuda as condições para a concessão de novos financiamentos aos projetos do Programa de Incentivo às Fontes Alternativas de Energia Elétrica (Proinfa). "Esperamos que a demanda chegue a 60 ou 70 $\mathrm{PCHs}$ no próximo ano",disse. A meta é ambiciosa, levando-se em conta o tímido desempenho do banco no ano de 2003, para o setor. Para se ter uma idéia, em 2003 o BNDES financiou apenas duas PCHs: a Hidrosol, do grupo Cassol, em Rondônia, e a Buriti, do grupo Folking, no Mato Grosso. "Recebemos uma listagem do Ministério de Minas e Energia apontando para mais de 60 projetos de $\mathrm{PCHs}$, cujos empreendedores mostraram interesse no Proinfa, que ainda não chegaram ao banco. Por isso, estamos procurando desenvolver condições para aumentar o nosso apoio", disse. Na carteira do BNDES há, atualmente, cerca de $15 \mathrm{PCHs}$ em avaliação. "O banco entende que a energia alternativa é fundamental para o Pais e estamos nos empenhando para que o programa seja bem sucedido", disse. Em 2003, o BNDES aprovou financiamento para 14 hidrelétricas, com capacidade de geração de 7 mil MW, com desembolsos previstos de R\$ 5 bilhões. Para 2004 , do orçamento estimado de RS 7 bilhöes, o banco pretende destinar mais de $30 \%$ às $\mathrm{PCHs}$ (http://www abrace.org.br/clipping/noticia) 
forma significativa, colaborando para a pressão sobre os recursos naturais, ao mesmo tempo que o número de postos de trabalho criados por unidade de energia consumida se contrapõe à retórica da "geração de empregos", comumente utilizada por essas empresas (Bermann, 2003).

Dessa forma, de acordo com dados apresentados em estudo, revela-se que são empreendimentos que asseguram apenas a ampliação da capacidade de produção de cada uma das empresas eletrointensivas envolvidas e que não existe a decantada folga para o sistema público. Pelo contrário, as usinas hidrelétricas licitadas para o regime de autoprodução subtraem do sistema público a desejável ampliação da oferta. Sem contar que, o autoprodutor, identificado como produtor de geração elétrica predominantemente destinada a seu uso próprio, pode comercializar, eventual e temporariamente, seus excedentes de energia, mediante autorização da Aneel, transformando-a em um negócio rentável (Bermann, 2003).

Ademais, a ANEEL, através do Decreto n. ${ }^{\circ} 2003$, de 10 de Setembro de 1996, acabou por atribuir ao produtor independente ou autoprodutor outro benefício. Conforme o Art. 30 deste decreto, a requerimento justificado do interessado, o poder concedente poderá declarar a utilidade pública, para fins de desapropriação ou instituição de servidão administrativa, de terrenos e benfeitorias, de modo a possibilitar a realização de obras e serviços de implantação de aproveitamento hidráulico ou de usina termelétrica, cabendo ao produtor independente ou autoprodutor 
interessado promover, amigável ou judicialmente, na forma da legislação especifica, a efetivação da medida e pagar as indenizações devidas.

Por tudo isso, a atual legislação, que considera todos os empreendimentos de geração como autoprodução e produção independente, deve ser revista. Ao retirar o caráter de serviço público que prevalecia antes da reestruturação do setor, no caso das usinas hidrelétricas, ela permite que o bem público representado pelo rio possa ser apropriado para responder as necessidades de natureza privada, no sentido estrito do termo.

Não obstante, as empresas e o governo deveriam respeitar os direitos das populações atingidas, não se utilizando do uso de pressão ou coação. para forçar as familias a saírem das terras ou aceitarem as negociações. Trata-se de garantir os direitos das populações atingidas, assegurando a reconstrução das suas condições de vida ou de participar melhor do processo decisório sobre a implementação da obra.

Enfim, com a reestruturação do setor elétrico nacional, o surgimento das figuras do Produtor Independente e do Autoprodutor, do direito do Transporte de Energia, e das privatizações das principais concessionárias. aliado aos incentivos governamentais, é que se vislumbra a possibilidade das PCHs passarem a ser encaradas como negócio. A repotenciação das antigas PCHs desativadas e a construção de novas, tomando a expressão concreta de uma concepção avançada de entender os négocios do setor elétrico - concepção que teria internalizado "preocupações com a sustentabilidade ambiental", no uso de novas tecnologias -, podem passar a 
ser uma atividade focal para o capital e, por isso mesmo, merecem ser objeto de uma análise critica (Tiago Filho, 1999). 
CAPÍTULO 2

\section{2 - REESTRUTURAÇÃO DO SETOR ELÉTRICO: Uma breve descrição dos modelos propostos}

Como já dito anteriormente, a partir dos anos 90, o Brasil passou a viver uma nova etapa de seu processo de desenvolvimento econômico. Diante da impossibilidade de prosseguir na gigantesca tarefa de promover o progresso por meio de investimentos em setores estratégicos, como telecomunicações, energia elétrica e transportes, em atendimento às crescentes demandas da sociedade, bem como em obediência às recomendações do sistema financeiro internacional, o Estado brasileiro decidiu se "reinventar", afastando-se da função empreendedora na área da infra-estrutura em favor da participação de agentes privados e dando atenção à outras de suas 'vocações' - a de fiscalizador da prestação de serviços públicos ${ }^{19}$.

A necessidade de mudanças já era sentida no setor de energia elétrica desde a década de 80 . Fragilidades eram crescentes no modelo então em vigor, mas apenas quando sufocados pela crise fiscal, o Estado e muitas de suas empresas começaram a sentir o peso de sua limitada capacidade para realizar investimentos.

\footnotetext{
${ }^{19}$ As primeiras bases legais para a reestruturação do setor elétrico brasileiro foram criadas em 1993, com a aprovação da emenda constitucional que permitiu a participaçāo de capitais estrangeiros no setor, mas foi só em 1995 que a modernização se tornou efetivamente possivel, com a regulamentação do Artigo 175 da Constituição de 1988, que atribuiu ao governo a responsabilidade pela prestação de serviços públicos, diretamente ou mediante concessão.
} 
A partir de 1990, o próprio Estado decide abandonar sua trajetória histórica de responsabilizar-se por investir em setores estratégicos e passa a priorizar o saneamento de suas contas, representando um dos mais importantes eixos para a política de reforma institucional e ajuste econômico, nos moldes exigidos pelo Fundo Monetário Internacional, desenvolvido na esfera de governo federal e descentralizado para os estados da federação.

Sob a justificativa da crise institucional e econômica do Estado brasileiro, e com base em argumentos tais como ampliação do atendimento com maior qualidade e menores tarifas, idealizou-se uma profunda e radical quebra de paradigma setorial, com a adoção de um modelo baseado ná desverticalizaçao da indústria, distinguindo-se seguimentos monopolistas (regulados) - transmissão e distribuição - e não monopolistas - geração e comercialização; privatização, e instituição de um modelo comercial baseado no comportamento competitivo dos agentes, e regulação técnica e econômica (independente) das atividades do setor (Sauer, 2002).

Conquanto não representasse a única alternativa, teórica ou operacional, para enfrentar os problemas que ocorriam e, tampouco, a forma mais adequada às características do sistema elétrico brasileiro, este modelo foi implementado, desconsiderando as formas contrárias ao longo do processo e foi uma das características mais marcantes da política iniciada pelo governo Collor (1990) e consumada nos governos FHC I e II (1994 à 2002). 
A partir de então, começou-se a construir ações visando privatizar as empresas estatais sob as alegações de necessidade de melhoramento da eficiência dos serviços prestados ao consumidor, de abater dividas e de se inserir com competitividade no cenário mundial. $E$, por meio de uma rede político-econômica nacional e pela influência exógena, o Brasil passou a realizar reformas em seus setores estratégicos (Leme, 2001).

Essa trajetória de reformas do setor, marcada por passos incoerentes e desarticulados, só adquiriu caráter mais abrangente, consistente e coordenado a partir de dezembro de $1996^{20}$, quando a consultoria Coopers \& Lybrand concluiu o estudo do modelo encomendado pelo Ministério de Minas e Energia e a Eletrobrás e, dentre suas principais recomendações, propôs:

* A criação do mercado atacadista de eletricidade (MAE);

* O estabelecimento de "contratos iniciais" para criar uma transição para o mercado de energia elétrica competitivo;

* O desmembramento dos ativos de transmissão e a criação de um Operador Independente do Sistema (OIS) para administrar o sistema interligado; e

* A organização das atividades financeiras e de planejamento neste novo cenário (Ferreira, 2000).

Mediante esse conjunto de propostas, o governo brasileiro passa a orientar as reformas político-institucionais que formataram um novo modelo para o setor energético do pais, bem como, a criação de algumas 
instituições capazes de regular e fiscalizar as novas regras desse novo modelo.

\section{1 - Descrição do $1^{\circ}$ modelo proposto}

No Brasil, a reestruturação do setor elétrico começou a materializar-se em 1993, com a promulgação da Lei Federal n. ${ }^{\circ} 8.631$, que eliminou o regime tarifário pelo custo de serviço, criando o Produtor Independente de Energia (PIE) e estabelecendo regras para a fixação de niveis tarifários, além de estabelecer a obrigatoriedade de contratos de suprimento de energia (contendo quantidade e preços) (Ferreira, 2000 apud Leme, 2001).

Em 1995, com a promulgação da Lei de Concessões n. ${ }^{\circ} 8.987$ e do Decreto n. ${ }^{\circ} 9.074$, os quais regulamentaram o artigo 175 da Constituição ${ }^{21}$, criaram-se condições legais para que os geradores e distribuidores de energia elétrica pudessem competir pelo suprimento dos grandes consumidores de energia elétrica.

Porém, como um marco na reforma regulatória do setor elétrico brasileiro, teve-se a criação da ANEEL (Agência Nacional de Energia Elétrica), pela Lei Federal n. ${ }^{\circ} 9.427 / 96$ e implementada pelo Decreto n. ${ }^{\circ}$ 2.335/97, cujo propósito era o exercício da função de órgão regulador em nível federal, apresentando-se como um melhoramento da tradição de

\footnotetext{
${ }^{20}$ No entanto, desde 1993, várias empresas vinham sendo privatizadas sem que o governo tivesse uma definiçäo concreta sobre as regras do novo modelo como, por exemplo, a Light, CERJ do Rio de Janeiro e Ecelsa do Espírito Santo.

${ }^{21} \mathrm{O}$ artigo 175 incumbiu "ao Poder Público, na forma de lei, diretamente ou sob regime de concessão ou permissão, sempre através de licitação, a prestação de serviços públicos. Parágrafo único. A lei disporá sobre: o regime das empresas concessionárias e permissionárias de serviços públicos, o caráter especial de seu contrato e de sua prorrogação, bem como as condições de caducidade, fiscalização e rescisão da concessão
} 
regulação das empresas de energia elétrica, antes exercido pelo DNAEE ${ }^{22}$. Também apresentava-se com o caráter de reordenar as áreas de negócios do setor em: produção de energia (geração); transporte nas tensões mais altas (transmissão); transporte com o objetivo específico de atendimento a consumidores finais (distribuição); e vendas no varejo, com a função de medir e conquistar consumidores finais (comercialização). Essa alteração desverticalizou o ordenamento do setor (Rezende e Paula, 1997apud Leme, 2001).

A ANEEL, na sua natureza jurídica, seria uma autarquia especial, o que permitiria ao órgão usufruir de relativa independência em vários aspectos, tais como: a) autonomia decisória e financeira; b) autonomia dos seus gestores; e c) delegação de competência normativa para regulamentar questões técnicas, conferindo neutralidade na solução dos conflitos e adoção de medidas (Pires, 1999). Ou seja, sua missão seria proporcionar condições favoráveis para que o mercado de energia elétrica se desenvolvesse com equilibrio entre os agentes e em benefício da sociedade.

Esses aspectos acabavam por dispensar a ANEEL de subordinação hierárquica direta, além de facilitar o estabelecimento de convênios com agências estaduais ${ }^{23}$, refletindo o caráter descentralizado do setor elétrico brasileiro, para o controle e fiscalização dos serviços e instalações de

ou permissão; os direitos dos usuários; política tarifária; a obrigação de manter serviço adequado".

22 DNAEE (Departamento Nacional de Águas e Energia Elétrica), órgão subordinado ao Ministério das Minas e Energia, fazendo com que as políticas setoriais, diretamente subordinada ao Poder Executivo, muitas vezes, buscassem por objetivos contraditórios, uma vez que deveriam observar por fatores microeconômicos (eficiência produtiva), macroeconômicos (controle inflacionário) e sociais (universalização dos serviços). 
energia elétrica, embora vinculada ao Ministério das Minas e Energia no cumprimento de contrato de gestão.

Com isso, esperava-se que as agências reguladoras, como a Aneel, fossem independentes operacionalmente e servissem para balizar os interesses do consumidor, do governo e das empresas privadas que prestassem serviços públicos, garantindo um mercado saudável, sem ingerência do governo nem abusos das empresas.

Quanto à introdução da competição na geração e na comercialização de energia, esta deveria fazer-se pelo emprego de uma série de mecanismos envolvendo estímulo à entrada (na geração) e a livre escolha do fornecedor de energia (na comercialização) por parte de consumidores com carga igual ou superior a $3 \mathrm{MW}$ e que fossem atendidos em tensão igual ou superior a $69 \mathrm{kV}$, liberando assim uma parcela expressiva de consumidores industriais da figura do consumidor cativo ${ }^{24}$.

No que tange à geração, um dos principais instrumentos adotados seria o estímulo à entrada de novos agentes, com uma maior flexibilidade aos interessados em participar da licitação, em que a mesma para a construção de novas plantas poderia ocorrer pelos critérios de menor tarifa do serviço a ser prestado ou pelo maior valor ofertado pela outorga, ou ainda pela combinação desses dois critérios ou pela combinação deles com a de melhor técnica.

${ }^{23}$ Como forma de exemplificar, citamos a Comissão de Serviços Públicos de São Paulo CSPE, que è o órgão regulador do setor elétrico no estado supra e mantém acordos formais para execução de muitas das competências da ANEEL no referido estado.

${ }^{24} \mathrm{O}$ consumidor cativo não tem opção de fornecimento de energia por outra empresa que não seja a concessionária local. 
Outra forma de fomento à geração seria via incentivos àqueles que buscassem construir ou recuperar usinas que fossem conectadas aos sistema interligado brasileiro sendo um claro exemplo disso Programa de Desenvolvimento e Comercialização de Energia em Pequenas Centrais Hidrelétricas $(\mathrm{PCH}-\mathrm{COM})^{25}$ em que a ELETROBRÁS garantia a comercialização da energia e, ainda, oferecia o BNDES com um possível financiador para o seu investimento e, mais tarde, o Programa de Incentivo à Fontes Alternativas de Energia (Proinfa).

Quanto à entrega física especificada nos contratos bilaterais, esta seria garantida por uma nova entidade, $0 \mathrm{OIS}^{26}$, órgão independente, sem fins lucrativos, o qual foi projetado para manter os benefícios técnicos do sistema centralizado de despacho. Com o objetivo de garantir o funcionamento "neutro" dos sistemas de transmissão, sua função era de evitar a possibilidade de práticas discriminatórias dos proprietários e, ao mesmo tempo, viabilizar o funcionamento cooperado do sistema. Dentre suas principais funções: a) a de garantir o livre acesso à rede de transmissão de forma não discriminatória; b) a de promover a otimização da operação do sistema elétrico, fazendo o planejamento e a programação da operação e o despacho centralizado da geração; c) a de incentivar a expansão do sistema ao menor custo; e d) administrar as redes básicas de transmissão.

\footnotetext{
${ }^{25}$ Nele a ELETROBRÁS acompanha a implantação, operação e manutenção da PCH, além de garantir a qualidade do projeto em relação à engenharia e ao meio ambiente (ELETROBRÁS, 2001).

26 O OIS seria responsável pela administração do sistema de transmissão (também conhecido como "rede básica"), definido de maneira tal que inclui as linhas de transmissão de $230 \mathrm{kV}$ ou superior.
} 
Em relação ao planejamento do setor energético, a Coopers \& Lybrand recomendou, ainda, que se fizesse um planejamento indicativo elaborado pelo Instituto para o Desenvolvimento do Setor Elétrico - entidade nova, sem fins lucrativos - englobando um período de 25 anos, um estudo das capacidades hidrológicas, a avaliação dos impactos ambientais e questões relacionadas, com o objetivo de encontrar os melhores propósitos para o investimento privado no setor sem a criação de prioridades predeterminadas e vinculadas ao investimento privado.

Contudo, devido a todas essas características pioneiras, o modelo orientado pelo mercado enfrentou vários problemas e desafios. O mesmo teve vários problemas: provocou acréscimos nas tarifas, levou à falta de energia, não atraiu investimentos e deixou as empresas endividadas.

Embora, para seus idealizadores, as causas de escassez de energia enfrentada pelo país tenham se dado devido à inconclusa implementação do modelo vigente, dada a permanência de grande parte da geração sob gestão estatal, ou a causas naturais, como a estiagem, a falta de investimentos em geração e transmissão de energia elétrica foi o motivo real (Sauer, 2002).

No período de 1991 - 2000, a demanda de energia cresceu em média $4,1 \%$, enquanto a oferta cresceu apenas $3,3 \%$. A defasagem entre oferta $\mathrm{e}$ demanda se acentuou a partir de $1995^{27}$, superando os $10 \%$ acumulados na

27 O Plano Real foi, em termos macroeconômicos, um dos aliados fundamentais da estratégia de reestruturação do setor elétrico e do papel do Estado no mesmo, que passa de investidor para financiador (via BNDES), fiscalizador e poder concedente. A falta de compasso entre a demanda e a oferta de eletricidade, fomentada pelo consumo desenfreado de eletro-intensivos, poucos e desacelerados investimentos em grandes hidrelétricas. O descompasso, que era identificado mesmo antes da estabilização monetária, só foi intensificado com esta e exigiu do Ministério de Minas e Energia (MME) novas formas de atuação, as quais são vislumbradas pelos gestores apenas como possivel dentro da via neoliberal; isto é, na garantia de condições de reentrada da iniciativa privada 
década. A questão é clara: faltou expansão. A capacidade de reservação expandiu abaixo do necessário, devido a falta de investimento em produção de energia (construção e recapacitação de usinas) (Sauer, 2002).

Por um lado, as empresas estatais foram impedidas de investir, como parte do cumprimento de acordos do país com o FMI, por outro, o capital privado que aqui aportou investiu preferencialmente, com a anuência do governo, em capacidade existente, agregando pouquíssima nova capacidade ao sistema (Sauer, 2002).

Para dar segurança ao abastecimento, minimizar os riscos para os investidores privados e garantir tarifas módicas aos consumidores, o Governo Lula propôs um novo modelo regulatório para o setor elétrico (Rousseff, 2003).

\subsection{Modelo do Setor Elétrico Proposto no Governo Lula (a partir de} Janeiro de 2004) ${ }^{28}$

Na primeira fase do Governo Lula (inicio em Janeiro de 2003), a questão do dilema: "estatização" versus "privatização" veio à tona e o MME adotou a interpretação de que o Estado teria que voltar a assumir sua responsabilidade de prever a expansão da oferta de energia necessária para garantir o desenvolvimento do país. Em seu artigo 174, a Carta Magna estabelece que o planejamento seja determinante para o setor público e

no setor, através do investimento em novas unidades geradoras que viriam propiciar a expansão da oferta de energia de forma mais rápida e eficiente, satisfazendo as exigências e expectativas da sociedade.

${ }^{28}$ Esta tese foi defendida em 16 Setembro de 2004, mesma data em que foi publicado no Diário Oficial o Decreto que regulamenta a Câmara de Comercialização de Energia Elétrica 
indicativo para o privado, o que torna a postura ministerial supra consoante com o dispositivo constitucional. Passe, assim, a fixar o conceito: o serviço de energia elétrica é parte integrante do setor público, ainda que realizado pela iniciativa privada.

O MME difunde a visão de que, quando o Estado está à frente da função de planejamento, estabelecendo as diretrizes e bases do planejamento do desenvolvimento nacional equilibrado (parágrafo 1 do Art. 174), a sociedade tem mais garantias que o direito do cidadão será preservado. Todavia, quando o Estado deixa de fazer este planejamento e deixa à mercê do mercado os melhores propósitos para o investimento, a sociedade passa a estar mais vulnerável aos interesses do capital privado ${ }^{29}$.

Logo, o Governo Lula assume um novo modelo regulatório, que resgata o planejamento da expansão da oferta de energia elétrica, cabendo a tarefa à Empresa de Pesquisa Energética - EPE -, cuja finalidade é prestar serviços na área de estudos e pesquisas destinadas a subsidiar o planejamento do setor energético. Sua competência é realizar: estudos e projeções da matriz energética brasileira; elaborar o balanço energético nacional; obter a licença prévia ambiental e a declaração de disponibilidade hídrica necessárias às licitações envolvendo empreendimentos de geração hidrelétrica e de transmissão de energia elétrica selecionados; elaborar estudos necessários para o desenvolvimento de planos de expansão da geração e transmissão de

(CCEE) ou seja, em meio ao processo de reestruturação do setor no Governo Lula e, por isso mesmo, novos percalços podem vir a ocorrer.

${ }^{29} \mathrm{Em}$ palestra recente, a atual ministra de Minas e Energia Dilma Roussef fez exatamente essa análise, acrescentando o argumento de que foi um equívoco tomar a ANEEL como forma institucional suficiente para cobrir a ausência de planejamento estatal, isto é, o 
energia elétrica de curto, médio e longo prazos; desenvolver estudos de impacto ambiental, viabilidade técnico-econômica e sócio-ambiental para os empreendimentos de energia elétrica e de fontes renováveis, entre outras funções. Os estudos e pesquisas desenvolvidos pela EPE passarão, assim, a ser tidos como subsídios à formulação, o planejamento e a implementação de ações do Ministérios de Minas e Energia, no âmbito da política energética nacional. (Decreto 5.184 de 16/08/2004).

Já o Comitê de Monitoramento do Setor Elétrico (CMSE) foi constituído no âmbito do Ministério de Minas e Energia e, sob sua coordenação direta, assume a função de acompanhar e avaliar permanentemente a continuidade e a segurança do suprimento eletroenergético em todo território nacional. (Decreto 5.175 de 09/08/2004).

Quanto aos futuros investimentos, o Governo Lula posiciona-se favoravelmente a que sejam feitos, preferencialmente, pela via das parcerias público-privadas (PPP), destancando-se que a alteração do modelo regulatório visa minimizar o risco dos investidores. Pela nova política, o retorno do investimento em geração, transmissão ou distribuição de energia e os parâmetros de ajuste tarifário passam a ser definidos no edital de licitação. (Roussef, 2003).

O novo modelo prevê a comercialização de energia elétrica entre concessionários, permissionários e autorizados de serviços e instalações de energia elétrica, bem como destes com seus consumidores no Sistema

esforço de pensar no longo prazo que é crucial para o setor elétrico (Palestra proferida no Sindicato dos Metalúrgicos do ABC, em São Bernardo do Campo, 10/08/2004). 
Interligado Nacional (SIN) em dois ambientes: Ambiente de Contratação Regulada ou Livre.

O Ambiente de Contratação Regulada - ACR é aquele no qual o segmento do mercado no qual se realizam as operações de compra e venda de energia elétrica se dá entre agentes vendedores e agentes de distribuição, precedidas de licitação, ressalvados os casos previstos em lei.

Já no Ambiente de Ċontratação Livre - $\mathrm{ACL}$, o segmento do mercado no qual se realizam as operáções de compra e venda de energia elétrica são objeto de contratos bilaterais livremente negociados, conforme regras e procedimentos de comercialização específicos.

Prevê-se que o Conselho Nacional de Política Energética - CNPE deverá propor critérios gerais de garantia de suprimento, com vistas a assegurar o adequado equilíbrio entre confiabilidade de fornecimento e modicidade de tarifas e preços.

Sucederá ao Mercado Atacadista de Energia Elétrica (MAE) a Câmara de Comercialização de Energia Elétrica (CCEE). Sua finalidade é viabilizar a comercialização de energia elétrica no Sistema Interligado Nacional (SIN), sob a regulação e fiscalização da Agência Nacional de Energia Elétrica (ANEEL). Visando assegurar a continuidade das operações de contabilização e de liquidação promovidas pelo MAE, a ANEEL regulará e conduzirá o processo de transição necessário à constituição e à efetiva operação do CCEE, a ser concluído no prazo máximo de 90 dias a contar da data de publicação deste Decreto 5.177 de 12/08/2004 (publicado no D.O de 16/08/2004). 
O marco regulatório elaborado pelo MME pretende dar conta da universalização do serviço, por meio do Programa Nacional de Universalização, bem como diversificar a matriz energética, com a ampliação do uso de fontes alternativas e a massificação do uso do gás.

À ANEEL caberá promover a articulação com os Estados e o Distrito Federal para o aproveitamento energético dos cursos de água e a compatibilização com a política nacional de recursos hídricos; celebrar e gerir os contratos de concessão ou de permissão de serviços públicos de energia elétrica; e expedir as autorizações e fiscalizar, diretamente ou mediante convênios com órgãos estaduais, as concessões e a prestação dos serviços de energia elétrica. Ou seja, a ANEEL cabe regular e fiscalizar o setor e ao MME formular políticas de curto, médio e longo prazos.

A exequibilidade de tais pretensões é algo que essa investigação, como tese concluída em Setembro de 2004, não pode acompanhar e analisar. Cabe aos estudos sócio-políticos que tomarem o recorte histórico seguinte a tarefa de verificação da efetividade desse novo desenho.

\section{3 - Uma Análise Crítica do Processo}

Após uma década de reforma, as promessas de ampliação da oferta, da qualidade e de confiabilidade dos serviços e da formulação de preços compativeis com a realidade não se realizaram. Ao contrário disso, a exacerbação de um ambiente de incertezas e falta de regras claras, diante de um precipitado processo de desverticalizaçao e privatização causou, entre os anos de 2001 e 2002, um racionamento de $25 \%$ do consumo de 
eletricidade, sob condições hidrológicas normais (3 anos com afluências acima da média e 2 abaixo da média) que afetou o crescimento econômico e as condições de vida de toda a sociedade (Sauer, 2002).

modelo privatista exigia que desafios fossem superados. No concernente à efetividade da agência reguladora, a falta de pessoal qualificado, o fato de ter sido criada após o início das reformas, dentre outros aspectos, dificultou o posicionamento do órgão no novo ambiente institucional, aumentando as incertezas regulatórias, as quais acabavam por fazer com que os investimentos em geração não ocorressem no volume necessário para a garantia da expansão da oferta, restringindo-se, basicamente, à retomada de obras paralisadas e à construção de novas usinas, por parte de produtores independentes e das novas concessionárias de distribuição interessadas em reduzir a sua dependência de suprimento até o limite de integração vertical estabelecido pela ANEEL (geração transmissão - distribuição) (Rosa, Tolmasquim e Pires, 1998) (Pires, 1999).

Outro problema enfrentado pelo referido modelo foi o de especificidade do caso brasileiro que valorizou o cunho econômico do processo prevalecendo este sobre os de caráter social e/ou ambiental. Dai porque, o Estado inseriu-se numa pseudo-modernidade global, renegando obrigações: obrigação de fundamentar suas decisões na conquista plena de direitos civis, políticos, econômicos, sociais e culturais de cidadania ainda vulneráveis a milhões de brasileiros; e de satisfazer as preocupações de caráter ambiental que deveriam estar transversalizadas em suas decisões de cunho político-econômico. 
Não era de todo irrelevante que o modelo supra tivesse levado em conta que o setor elétrico brasileiro apresenta características que o diferenciam de qualquer outro no contexto internacional, ${ }^{30}$ quais sejam:

- limitações para a introdução em um ambiente competitivo (no nível da oferta) no mercado internacional de energia em razão da defasagem de investimento em sua base geradora e por ser a mesma predominantemente hidráulica (95\%), com a geração térmica exercendo a função de complementaridade nos momentos de pico do sistema. Se, por um lado, essa característica cria um cenário de acumulação efetiva in loco, pelo efeito da demanda reprimida, coloca tal demanda apenas no mercado em que os meios de pagamento à vista são realizados em moeda desvalorizada perante a divisa ora estabelecida, o dólar americano, o que traz implicações para o êxito, por exemplo, deste "modelo único" na efetivação de um mercado de gás natural a partir do empreendimento Bolívia/Brasil;

- É elaborado sob uma estrutura federativa de governo, no qual a geração de energia elétrica pode desenvolver-se, durante décadas, a partir da criação de concessionárias estaduais, que, por sua vez, tornaram-se monopólios estatais. Este foi o caso da CESP em São Paulo ${ }^{31}$; da CEMIG em Minas Gerais, dentre outras.

30 Tendo no cenário internacional - além do Brasil -, apenas a Noruega com a presença majoritária de fontes hidráulicas ${ }_{31}$ A antiga CESP, em Abril de 1999, passou por uma cisão parcial em
geração e uma de transmissão de energia elétrica foram criadas, à saber: Companhia de 
Esta situação, de relativa autonomia dos Estados da Federação perante os demais e à União, passa a ser vista como "um problema político" quando há desencontros na concepção econômica e/ou energética adotada por tais instâncias de governo e, portanto, tensiona fortemente como um modelo que se pauta num ambiente de proteção às iniciativas particulares de empreendedores.

Se a articulação política não logrou êxito na busca de consensos, o processo de abertura do mercado de energia aos atores acima referidos não poderia continuar a ocorrer conforme o "modelo único ótimo de implementação"; começaria haver sérios comprometimentos para o cronograma de reformas e elevação do chamado "risco-país" no mercado internacional.

Mais uma vez, tem-se um quadro sócio-político em que a formatação histórica endógena, colocando a esfera do Executivo estadual e federal em mesmo patamar de decisão, agiu segundo variáveis para além dos interesses do mercado.

Ademais, a relação que poderia se estabelecer entre novos investimentos (privados) em geração elétrica (seja por usinas hidrelétricas ou usinas térmicas a gás que utilizam água no processo de resfriamento) e o manejo e acesso aos recursos hídricos pelos demais usuários em uma época/região de iminência de escassez de água, traz dois conflitos latentes, imbricados um no outro, a saber: a) a tendência de deterioração de um ambiente social onde se deveria procurar consensos, diminuindo as 
condições de cumprimento dos requerimentos legais maiores (constitucionais) que priorizam determinados usos sobre os outros; b) e a tendência do comportamento individualista e hegemônico do empresariado do setor elétrico renegando não apenas os direitos sociais de outrem, mas o direito à vida das demais espécies que dependem da água, o que amplia a suscetibilidade dos ecossistemas aquáticos naturais (ou terrestres, que da integridade deste dependam).

Ou seja, para enfrentar o esgotamento do modelo de desenvolvimento centralizador, o Brasil optou por adotar um outro, privatista, prenhe de limitações.

Nesse processo, o Estado aspirou que houvesse aumento da produtividade e na eficiência do setor e, para tal, buscou introduzir um ambiente competitivo na geração e comercialização de energia elétrica, mesmo que para isso houvesse a necessidade de contratos iniciais com acordos entre velhas concessionárias de energia, produtores independentes e autoprodutores ${ }^{32}$. Aplicou, ainda, novas formas de regulação aos segmentos que, a principio, permaneceriam como monopólio (transmissão ${ }^{33}$ e distribuição), como medidas paliativas para o não comprometimento da coordenação operativa do sistema elétrico.

Mas novas reformas foram necessárias.

Geração de Energia Elétrica de Paranapanema e Companhia de Transmissão de Energia Elétrica.

${ }^{32}$ Produtor Independente de Energia Elétrica: a pessoa juridica ou empresas reunidas em consórcio que recebam concessão ou autorização para produzir energia elétrica destinada ao comércio de toda ou parte da energia produzida, por sua conta e risco;

Autoprodutor de Energia Elétrica: a pessoa física ou jurídica ou empresas reunidas em consórcio que recebam concessão ou autorização para produzir energia elétrica destinada ao seu uso exclusivo. (Decreto n. $\left.{ }^{\circ} 2003,10 / 09 / 1996\right)$ 
Assim, o caso brasileiro apresenta dificuldades de implementação de mudanças tanto no que se refere às de natureza político-econômico e institucional, quanto nas de natureza física do sistema.

E a reestruturaçào parece ter, ainda, um longo caminho a percorrer. Só atingirá o seu objetivo - maior produtividade e melhor eficiência - após um melhor desenvolvimento dos aspectos institucionais e regulatórios, que acabe por construir um ambiente propício aos investimentos com garantias para a expansão da capacidade geradora do sistema, ao mesmo tempo em que sejam asseguradas a modicidade, a continuidade, qualidade e universalização do serviço, que o Governo Lula anuncia, mas cujo êxito ainda está por vir.

\footnotetext{
${ }^{33}$ A transmissão continuaria como monopólio gerido pelo Operador Nacional do Sistema Elétrico (ONS).
} 


\section{3 - O MEIO AMBIENTE NA PAUTA DO PROCESSO DE TOMADA DE}

\section{DECISÃO: O setor elétrico em perspectiva}

Ao longo do século $X X$ e deste que se inicia, nosso planeta vem sofrendo marcantes transformações em seus ricos e variados ambientes naturais, onde planta-se; desmata-se, constrói-se, destrói-se etc., sendo todas ações empreendidas com o objetivo de ajustar as características do ecossistema Terra às demandas sociais e, mais intensamente, ao modo de produção atual, cujo estágio presente permite atuação das técnicas em escala global.

Essa evoluçäo culmina, na fase atual, na representação social de que a qualidade de vida está em dependência direta da produçào material da sociedade, da diversificação dos produtos e serviços, surgindo uma multiplicidade de necessidades a serem satisfeitas. O progresso técnico é, portanto, um fator estratégico de manutenção desse significado cultural fortemente arraigado e que absorve quantidades cada vez maiores de insumos industriais e energéticos (Furtado, 1977).

Verifica-se, então, a passagem de uma ordem vital a uma ordem racional na qual a natureza é instrumental à sociedade, portanto. domesticada, com o papel hoje único da mercadoria, incluindo a mercadori:ı política (Santos 1998).

Por sua vez, a espacialidade desse processo tem sido constantemenl" redefinida e reforça-se cada vez mais a reprodução dessa mesma dinârniı :1 
sobre territórios e culturas até então ao abrigo das tradições, de modo que a expansão do capitalismo apresenta-se, atualmente, como modo de produção mundial (lanni, 1995). Seu espaço amplia-se até a negação das fronteiras nacionais, por meio da subordinação progressiva da política e dos povos à vida econômica e esta, por sua vez, subordina-se a um único sistema econômico de mercado. As corporações transnacionais, incluindose naturalmente as organizações bancárias, movimentam seus recursos, desenvolvem suas alianças estratégicas, agilizam suas redes e seus circuitos informáticos e dispersam-se pelo mundo segundo planejamentos próprios, geoeconomias independentes, avaliações econômicas, políticas, sociais e culturais que muitas vezes contemplam muito pouco as fronteiras nacionais ou os regimes políticos nacionais. (lanni, 1995).

O conseqüente estreitamento da interdependência entre os países em termos de recursos naturais, embora visto como possibilidade da nova reequalização do poder, não o é, de fato: as carências financeiras que aviltam alguns colocam suas disponibilidades naturais em uma relação de trocas pouco justa para as finalidades de retomada de alguma soberania (French, 1993; Harvey, 1993; Jimenez, 1994 apud Barros, 1996). E, assim, também, por pressão exógena que nascem as demandas por desestatização, desregulamentação, privatização, abertura de fronteiras, criação de zonas francas, que, depois, vão buscar legitimação junto à opinião pública no espaço de inserção como a melhor, senão única saída, para os países em esfera global adotarem. 
O Estado, como se sabe, caracteriza-se por três elementos essenciais: o território, o povo e o governo, enquanto a nação é caracterizada pela coexistência do território e do povo, mesmo inexistindo governo e, conseqüentemente, o Estado. Sob o paradigma neoliberal, o mesmo pretende reduzir suas funções ao mínimo em favor das regras de mercado, isto é, partindo que os interesses privados possam transitar ao sabor das demandas e dos riscos.

Um dos aspectos que distingue o neoliberalismo recente daquele que eclodiu um século antes é o fato de que ele diz respeito à vigência e generalização das forças do mercado em âmbito global tanto quanto se vê obrigado a lidar com uma nova 'externalidade': a externalidade ambiental. (lanni, 1995).

Dada a voracidade da desnaturalizacao do espaço sobre o qual o capitalismo se desenvolve, seu conteúdo relacional não seria outro senão a apropriação cada vez mais expressiva do capital sobre a natureza, sujeitando-a ao reducionismo utilitarista dos recursos naturais e a degradação de toda ordem, com fortes repercussões sobre a lucratividade do próprio capital, seja por promover o encarecimento do produto, seja pela necessidade de inversão de capitais adicionais à pesquisa e uso de matérias básicas cada vez mais industrializadas (Moraes e Costa, 1987).

A grande recessão econômica mundial no início da década de 70 , devido à Crise do Petróleo, também contribuiu para que se observasse a necessidade de incorporar a questão ambiental - no caso, a escassez de recursos - aos processos de desenvolvimento, onde a energia aparece em 
destaque dado o seu elevado consumo, bem como em suas importantes alterações produzidas no ambiente.

Como o processo econômico não se auto-sustenta, pois ele não existe em um vácuo nem se dá isoladamente em relação ao meio ambiente no qual repousa, qualquer mudança na ordem natural desse meio ambiente pode acarretar alterações de caráter muitas vezes inesperado e irreversivel, comprometendo a saúde do subsistema econômico, fortemente dependente do equilibrio do sistema ambiental (Cavalcanti, 1995).

O novo desafio passou a ser, então, assegurar que as relações (econômicas, políticas e sociais) entre os elementos do sistema (pessoas e lugares), além de serem voltadas para o crescimento econômico, estejam também atentas à conservação do meio ambiente dada a gênese do processo, ou seja, o modo de produção, o qual é dependente da base biofísica (Elliot, 1994).

Embora tal debate não ensejasse uma crítica contundente ao capitalismo, ao menos foi de supor que incitasse reflexões mais consistentes acerca dos efeitos deletérios da fase atual de desenvolvimento das forças produtivas dentro deste modo de produção, mesmo que ainda procurando sua legitimação, por meio de soluções para que o ambiente suporte suas pressões, identificadas como sinal de "progresso", tecendo uma mediação particular, nem por isso mais sustentável, com o ambiente natural (Moraes e Costa, 1984 apud Martins e Valencio, 2004). 


\section{1 - O ambientalismo: do movimento alternativo à institucionalização}

Se, por um lado, têm prevalecido os interesses das grandes empresas mundializadas, movidas por interesses financeiros, que se servem da tecnociência com um espírito exclusivo do lucro, por outra parte, começa a emergir por parte de vários grupos sociais, a aspiração por uma nova ética em antítese à da predação e aos efeitos irracionais que se manifestam com a preponderância progressiva do tipo de relação sociedade/natureza, configurado pelo aumento dos níveis e da complexidade desse consumo, concomitante com o aumento dos níveis de degradação ambiental, outra não sendo a razão da utilização dos recursos naturais como matéria-prima e fonte de energia numa intensidade sem precedentes, mesmo que justificados sob o lema básico do "desenvolvimento".

De outra forma, a percepção ampliada da ação (des) estruturante dos processos econômicos sobre o meio ambiente levou à promoção de ideais de conservação e proteção e dois outros acontecimentos vieram enfatizar a questão ambiental na agenda de problemas mundiais. O primeiro, foi a publicação do relatório denominado "Os Limites do Crescimento" (Clube de Roma, 1972), o qual alertava para a escassez de diversos recursos naturais, em decorrência de sua exploração desenfreada. O segundo, em Estocolmo, em 1972, na Conferência das Nações Unidas sobre Meio Ambiente Humano na qual, pela primeira vez, um número significativo de países se reuniu para discutir aspectos relativos ao meio ambiente e sua relação com o desenvolvimento. 
Problemas de poluição e de desperdício tornaram-se um dos focos de combate dos movimentos ambientalistas, os quais pressionavam para a adoção de novas formas político-institucionais reguladoras do uso da base biofísica. Isto é, formas que se preocupassem com a depleção da base de recursos naturais, com a superação ou refreamento dos sistemas produtivos que utilizam tecnologias poluentes e de baixa eficiência energética e com a disseminação de sistemas de valores diversos daqueles que tem propiciado a expansão ilimitada do consumo material (Viola et al., 1992).

Na década de 80, o conceito de desenvolvimento passou a adquirir um caráter multidimensional em que as sociedades deveriam melhorar como um todo. Buscava-se, então, formular políticas para a ação que integrassem o meio ambiente às práticas de desenvolvimento e à racionalização do uso dos recursos naturais, de maneira à atender as necessidades da geração presente sem comprometer as necessidades das gerações futuras. Quanto aos limites, estes seriam dados pelos estágios da tecnologia e da organização social, pela capacidade da biosfera em absorver os efeitos das atividades humanas e pela possibilidade de a gestão ambiental articular todos esses fatores. A publicação Our commom future (Nosso futuro comum), elaborada pela Comissão Brundtland em 1987, trouxe os princípios básicos para essa nova ordem ${ }^{34}$.

\footnotetext{
34 Depois da Conferência de Estocolmo (1972), vários congressos e conferências abordando diversos aspectos da questão ambiental foram realizados e culminaram, em 1983, na criaçäo da Comissão Mundial sobre Meio Ambiente e Desenvolvimento (CMMAD), cujo trabalho resultou na publicação do relatório "Nosso Futuro Comum", também conhecido como Relatório Brundtland, o qual trouxe, pela primeira vez de uma forma sistematizada, uma conceituação de desenvolvimento sustentável, cuja forma resumida é: "O desenvolvimento sustentável é aquele que atende as necessidades do presente sem comprometer a possibilidade de as geraçōes futuras atenderem a suas próprias necessidades".
} 
Pensava-se que, depois da institucionalização multilateral, do direito às liberdades individuais, dos direitos políticos e dos direitos sociais, com o ambientalismo surgisse a preocupação com os chamados "direitos da terceira geração", isto é, aqueles em que os sujeitos não são limitados aos grupos sociais do presente; ultrapassa-se os interesses desta geração para relativizá-los perante os interesses dos que estão por vir, recuperando-se, com isso, o comprometimento com a humanidade e, desta, a sinergia com seu habitat, de modo a tornar suas práticas mais sustentáveis para suprir as necessidades de todas as demais formas de vida, incluindo as das gerações futuras (Bobbio, 1992 apud Barros, 1996).

Neste sentido, a década de 1990 constituiu-se em momento relevante para o entendimento da problemática ambiental no Brasil. Nela, houve a pretenção do governo brasileiro, que foi apoiada pela ONU, de sediar a Conferência das Nações Unidas sobre Meio Ambiente e Desenvolvimento (CNUMAD - 92) - buscando-se maiores fundamentos para a concepção do desenvolvimento sustentável. A necessidade de pensar as relações entre desenvolvimento econômico e proteção ambiental estimulou o debate entre os vários setores da sociedade, tanto quanto corroborou para que a questão ambiental fosse traduzida em uma legislação mais avançada.

E em se tratando do tema meio ambiente, esse gerenciamento assume um significado muito mais amplo, pois deve envolver um grande número de variáveis que interagem simultânea e sinergicamente a fim de conciliar desenvolvimento e qualidade ambiental. Essa conciliação, por sua vez, deve acontecer a partir da observância da capacidade suporte do meio 
ambiente e das necessidades identificadas pela sociedade civil ou pelo governo (situação mais comum) ou ainda por ambos (situação mais desejável) ou, depois da globalização da economia, das pressões do mercado.

Mas, nota-se que a responsabilidade ambiental nem sempre faz parte da estratégia das empresas, a não ser que esta receba sinais claros e positivos do mercado, constituindo-se até em um mercado promissor - um novo produto/serviço a ser vendido - diferenciando a política de marketing e de competitividade, fomentando a difusão de inovações tecnológicas (processos e produtos) que reduzem ou eliminam a poluição (Maiman, 1994).

Por isso, estas necessidades identificadas pelos diversos setores da sociedade encontra na legislação, na política ambiental e em seus instrumentos suas ferramentas de ação. Ela qualifica a ação institucional do poder público no sentido de implementar a política de meio ambiente e deve ser entendida como uma ação pública, empreendida por um conjunto de agentes caracterizado na estrutura do aparelho do Estado, que tem por objetivo precípuo aplicar a política ambiental no país (Moraes, 1994 apud Souza, 2000).

O problema, no caso brasileiro, é que o país possui um Estado comprometido com interesses dominantes internos (empresas motrizes, muitas vezes, corporações transnacionais) e interesses financeiros externos (organizações bancárias internacionais), conseqüência do próprio processo de formação do Estado em que, apesar de suas grandes extensões e 
'infinitos' recursos, possui um sociedade desorganizada e desmobilizada no que se refere às questões ambientais e diante da necessidade de reivindicação por seus direitos (Santos, 1992).

Dessa maneira, a ação do governo dá-se em um universo social de interesses conflitantes, em que a satisfação de propósitos individualistas chega a limite e atinge negativamente o conjunto da sociedade. O espaço político ambiental é essencialmente um espaço de gestão de conflitos entre as ações da máquina estatal, controlada pela classe dominante (formadores de opinião), e as organizações sobre o meio ambiente da sociedade civil (Souza, 2000).

Assim, a complexa teia de relações sócio-ambientais dificilmente consegue ser apreendida pelas estratégias que costumam ser colocadas em prática por empreendedores em geral e do setor elétrico, em particular. fato dos interesses privados dos concessionários não coinciderem com os interesses e necessidades de vários segmentos sociais afetados por suas obras configura uma situação na qual o bem comum dificilmente será priorizado e, muitas vezes, pode ser passível de não atendimento. Mesmo porque as questões ambientais afetam a coletividade de maneira difusa e, como o homem age de acordo com seus próprios interesses, a destruição do meio encontra poucos agentes privados motivados à combatê-la, ainda mais quando o assunto for geração de energia para o desenvolvimento do país (Moraes, 1994).

Por isso, a fim de se obter maior eficiência no gerenciamento do meio ambiente, passa pela exigência de um modelo institucional descentralizado, 
com fóruns institucionais de interlocução, ou seja, canais de discussão política entre a sociedade civil e os governos locais, pelo fato da escassez ecológica não ser determinada exclusivamente pelas condições naturais e, muito mais, pelas formas vigentes de apropriação social e exploração econômica da natureza, o que nos deve levar ao resgate de valores culturais específicos de cada região quando do processo de tomada de decisão (Leff, 1986).

\section{2 - A Introdução da Questão Ambiental na Agenda do Setor Elétrico}

\section{Nacional}

No Brasil, no que concerne ao meio ambiente, da mesma forma que o movimento ambientalista como um todo, até o final da década de 70 , as questões ambientais eram tratadas de maneira descentralizada, delegando às concessionárias a elaboração dos seus programas. Mas, de maneira geral, estes programas e diretrizes possuiam um enfoque reativo, no qual visavam basicamente a correção dos problemas causados pela implantação dos empreendimentos.

A partir da década de 70 , com a construção dos reservatórios de grande porte ocupando áreas e regiões tropicais, cujos alagamentos de florestas e dinâmica dos ecossistemas acabavam por determinar a eutrofização do ambiente e a produção de gases - que acabavam por comprometer a vida útil das próprias instalações -, passou-se a atentar aos primeiros programas de qualidade da água de reservatórios, de cobertura vegetal das áreas inundadas, de recuperação das áreas degradadas por 
empréstimos e deposição de sedimentos, bem como o de "salvamento" da fauna terrestre.

Isso porque, mesmo o movimento ambientalista desenvolvendo-se num contexto internacional, tem-se a sua especificidade calcada na estrutura nacional de oportunidades políticas e econômicas de cada país. A própria conferência da ONU, em Estocolmo, em 1972, teve um impacto mínimo na opinião pública brasileira, se comparado não apenas com os países desenvolvidos mas, também, com outros países do Terceiro Mundo como a Índia e a Venezuela ${ }^{35}$

A gradativa mudança de postura só foi possível graças à intensificação dos protestos e reinvidicações da sociedade organizada, a partir da década de 80 , com um período de transição até o ano de 1986, durante o qual medidas concretas com relação ao controle ambiental foram mais significativas.

Neste período de transição, destaca-se a sanção da Lei Federal n. ${ }^{\circ}$ 6.938, de 31/08/1981, que dispõe sobre a Política Nacional do Meio Ambiente, seus fins e mecanismos de formulação e aplicação e, onde surge, inspirado no direito americano (National Environmental Policy Act - NEPA de 1969), que introduziu a Avaliação de Impacto Ambiental (AIA) nos EUA, devido à pressões de grupos ambientalistas às limitações das análises estritamente econômicas e técnicas dos empreendimentos, a AIA no Brasil, como um dos instrumentos da referida Lei Federal n. ${ }^{\circ} 6.938$, bem como

35 O país, inclusive, tinha liderado na conferência muitas das batalhas contra o reconhecimento da importância da problemática ambiental. Além disso, a política econômica estimulava diretamente a transferência, para o Brasil, das indústrias mais 
constitui o Sistema Nacional do Meio Ambiente (SISNAMA) e cria o Conselho Nacional do Meio Ambiente (CONAMA).

Entretanto, medidas concretas com relação ao controle ambiental só foram mais significativas com a publicação da Resolução n. ${ }^{\circ} 001$ do CONAMA, aos 23/01/1986 onde, baseando-se no Decreto n. 88.351 de $01 / 06 / 83^{36}$ e no Art. 8 da Lei Federal n. ${ }^{\circ} 6.938 / 81$, deu tratamento mais orgânico à Avaliação de Impacto Ambiental, já que estabeleceu as "definições, responsabilidádes, critérios básicos e suas diretrizes gerais" e, a partir do qual, o enfoque reativo que orientava a maioria das ações cedeu lugar a uma abordagem pró-ativa, de natureza sistemática e abrangente, em que as questões ambientais deveriam fazer parte do processo de tomada de decisão.

Para o setor elétrico, essa abordagem pró-ativa veio com a publicação, em junho de 1986, pela Eletrobrás, do Manual de Estudos de Efeitos Ambientais dos Sistemas Elétricos, que se constituiu em um guia que coloca em ítens e detalha os aspectos ambientais e sociais nas diversas etapas dos empreendimentos elétricos.

Seguida dessa publicação, mais um trabalho na área ambiental veio complementar a regulamentação na condução da questão no setor elétrico, o Plano Diretor para Proteção e Melhoria do Meio Ambiente nas obras e serviços do setor elétrico (I PDMA), publicado em novembro de 1986, que propôs uma política ambiental para o setor com base em quatro temas prioritários: (inserção regional; remanejamento de grupos populacionais; 
tratamento das interferências do setor com populações indígenas; flora, fauna e carvão) $)^{37}$.

O avanço na legislação exigiu, ainda, que fossem criados mecanismos legais que regulamentassem o setor elétrico e, nesse sentido, as principais concessionárias, em conjunto com os representantes dos órgãos ambientais estaduais, o Departamento Nacional de Águas e Energia Elétrica (DNAEE) e a Secretaria Especial do Meio Ambiente (SEMA) aprovaram, junto do Conselho Nacional do Meió Ambiente (CONAMA), a Resolução n. ${ }^{\circ}$ 006/87, em que fica especificada as diretrizes para o licenciamento de empreendimentos de geração e transmissão de energia elétrica e veio complementar a anterior, Resolução n. ${ }^{\circ}$ 001/86.

Em abril de 1988, o então Ministério das Minas e Energia criou o Comitê Coordenador de Atividades de Meio Ambiente do Setor Elétrico (Comase), um órgão deliberativo onde eram debatidas as principais questões sociais e ambientais que afetaram o setor elétrico, estabelecendo as linhas de políticas que deveriam ser seguidas e, o processo de internalização das questões ambientais no âmbito do setor, culminou, ainda, com a elaboração, em 1990, do II PDMA que realimentou a política ambiental para o setor.

O terceiro - e último - período teve início com a publicação da Constituição Federal (CF) de 1988, em que, reconhecendo-se o direito à

(Guimarães, 1986 apud Viola, 1992).

${ }^{36}$ Hoje esse decreto regulamentar foi substituido pelo Decreto n. ${ }^{\circ} 99.274$, de 06/06/90.

37 Estas propostas contidas no I PDMA refletem um grande avanço no trato das questöes ambientais do setor elétrico e, para que estas propostas pudessem ser efetivamente implementadas cria-se, em dezembro de 1986, o Comitê Consultivo de Meio Ambiente da 
qualidade do meio ambiente como manifestação do direito à vida, produziuse um texto inédito em constituições em todo o mundo, capaz de orientar uma politica ambiental no pais e de induzir uma mentalidade preservacionista como, por exemplo o Art. 225 de CF ${ }^{38}$. (Milaré. $^{39}$ in Plantenberg e Ab'Saber, 1994).

Contudo, mesmo a importância discursiva da questão ambiental tendo sido traduzida em uma legislação comparativamente avançada, esta não se consolidou nos anos que se seguiram e, embora o ambientalismo tivesse, no Brasil, adotado uma gama de vertentes, ao sabor de um conjunto de interesses, os mais distintos, essas distinções ainda assim permitiram a construção de uma pressão social a favor da implantação de políticas que desencadearam processos de desequilíbrio e de degradação ambiental. As políticas públicas nacionais encontram-se entre um discurso-legislação bastante "ambientalizado" e um comportamento individual-social bastante predatório, em que o poder político foi incapaz de fazer com que indivíduos, empresas e ele próprio cumprissem tal legislação sem percalços (Viola e Leis, 1992).

Tais percalços vão desde a incapacidade material e de quantidade de recursos humanos para fazer cumprir as leis até a assimilação inadequada (biocentricamente referida) dos princípios dessa nova legislação,

Eletrobrás (CCMA) e, paralelamente, constitui-se o Departamento de Meio Ambiente (DPA), em agosto de 1987, também na Eletrobrás.

${ }^{38}$ Com efeito, considerando o meio ambiente "bem de uso comum do povo e essencial à sadia qualidade de vida", impôs ao poder público, para assegurar a efetividade desse direito, a incumbência de "exigir, na forma de lei, para instalação de obra ou atividade potencialmente causadora de significativa degradação do meio ambiente, estudo prévio de impacto ambiental, a que se dará publicidade". (Art. 225 da CF).

${ }_{39}$ Milaré, E. (1994). Estudo Prévio de Impacto Ambiental no Brasil. 
confrontando-se com princípios consagrados do direito social (Souza, et al.,2002).

Entretanto, considerando o grande número de leis, decretos, resoluções sobre o meio ambiente, como visto acima, dois diplomas de caráter absolutamente inéditos na legislação ambiental brasileira foram promulgados e se, de um lado, não chegaram a constituir-se em um reordenamento da legislação ambiental, de outro, seguramente consistiram em importante instrumento para sua plena realização.

O primeiro trata-se da Lei Federal $n .^{0} 7.347 / 85^{40}$, que disciplinou a ação civil pública de responsabilidade por danos causados ao meio ambiente e outros interesses difusos. A partir de então, os bens de interesse comum do povo (difusos) passaram a receber a tutela do Ministério Público, sendo este instituído como principal titular da ação judicial, muito embora as ONGs ou associações legalmente constituídas também possam promover a defesa dos bens públicos (não individuais) lesados.

O segundo diploma, corresponde à Lei Federal n. ${ }^{\circ}$ 9.605/98, conhecida como a Lei dos Crimes Ambientais. Fundamentado na Constituição Federal de 1988, cujo capítulo reservado ao meio ambiente autorizou a desenvolver novos instrumentos legais que responsabilizassem civil e criminalmente os degradadores do meio ambiente. Ao contrário da legislação anterior, que pautava-se essencialmente na esfera do direito civil,

\footnotetext{
${ }^{40}$ Por essa Lei, todas ações lesivas aos bens difusos, como é o caso do meio ambiente, ficam passiveis de punição. E essa punição pode se dar por meio da execução de medidas de recuperação ou mitigação pelos danos provocados ao meio ambiente, ou ainda como indenização por atividade exercida de forma nociva ao ambiente natural.
} 
a Lei dos Crimes Ambientais, passou a possibilitar que pessoas físicas e jurídicas sejam processadas criminalmente, o que instituiu uma nova vertente na defesa desse patrimônio da humanidade.

\section{3 - Gestão do Meio Ambiente X Gestão de Energia: Compatibilidades e Incompatibilidades}

Das principais fontes de geração de energia elétrica, a energia hidráulica se firmou no Brasil, ao longo dos anos, como a fonte primária mais importante de energia (responsável por aproximadamente $95 \%$ da matriz elétrica nacional), não só pelo montante do potencial disponível, dada a imensa quantidade de rios que cobre o País, mas também por sua atratividade econômica. (Eletrobrás, 1990) Identificando-se a problemática da questão ambiental para equacionar seu aproveitamento.

Hoje, porém, na esteira do desenvolvimento da tecnologia de construção civil das usinas hidrelétricas, os técnicos do setor foram induzidos por uma forte pressão externa à adotarem práticas de proteção e controle do meio ambiente as quais se refletiram, em um primeiro momento, na Avaliação de Impacto Ambiental (AIA), que se configura em uma importante ferramenta para avaliar as possíveis intervençőes do empreendimento no meio em que se insere (Mariotoni e Badanhan, 2001).

Para Chambault apud Machado (1991) "a função do procedimento de avaliação não é influenciar as decisões administrativas sistematicamente a favor das considerações ambientais, em detrimento das vantagens econômicas e sociais suscetíveis de advirem de um projeto". O objetivo é 
dar "às administrações públicas uma base séria de informações, de modo à poder pesar os interesses em jogo, quando dá tomada de decisão, inclusive àqueles do ambiente, tendo em vista uma finalidade superior".

Ainda, segundo o autor, a avaliação é de elaboração obrigatória e, conseqüentemente, não facultativo para todas as obras e atividades, cuja instalação possa provocar significativo impacto ambiental ${ }^{41}$. Não podendo ser realizado concomitantemente a obra ou a atividade, nem posteriormente as mesmas. É prévio, send́ que as verificações e análises terminam por um juízo de valor, ou seja, uma avaliação favorável ou desfavorável ao projeto em que não se admite um estudo de impacto ambiental (EIA $)^{42}$ que se abstenha de emitir a avaliação do projeto, conforme Quadro 2.

${ }^{41}$ Com base no Conselho Nacional do Meio Ambiente (CONAMA), Resoluçäo n. ${ }^{\circ} 001$, de 23 de Janeiro de 1986, Art. 1., Considera-se impacto ambiental qualquer alteração das propriedades físicas, químicas e biológicas do meio ambiente, causada por qualquer forma de matéria ou energia resultante das atividades humanas que, direta ou indiretamente, afetam:

1. $\quad$ a saúde, a segurança e o bem-estar da população;

2. as atividades sociais e econômicas;

3. a biota;

4. as condições estéticas e sanitárias do meio ambiente;

$5 . \quad$ a qualidade dos recursos naturais.

42 Para Andreoli e Fernandes (1996) in IAIA (International Association for Impact Assessment), o Estudo de Impacto Ambiental (EIA) é um instrumento de caráter técnicocientífico que subsidia uma das etapas da Avaliação de Impacto Ambiental (AIA), sendo esta etapa, dentro do processo de AIA, a que possui maior conteúdo técnico-científico e também que consome mais tempo e recursos. 


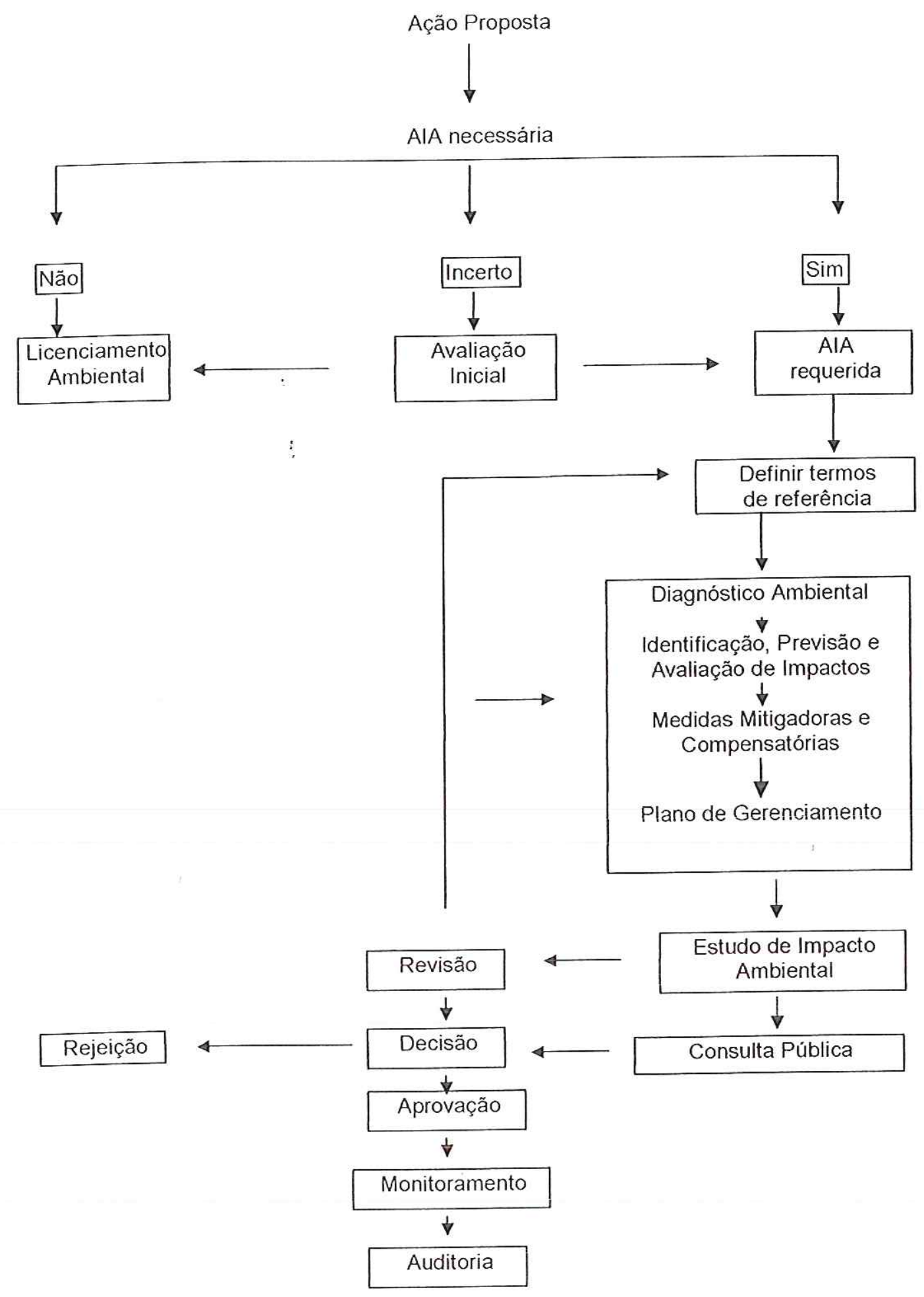

Quadro 2: Principais componentes do processo de Avaliação de Impacto Ambiental (AIA) (Andreoli e Fernandes, 1996). 
Regulamentando a Lei Federal n. ${ }^{\circ} 6.938 / 81$, que institui a AIA como um dos instrumentos da Política Nacional do Meio Ambiente, o Decreto n. ${ }^{\circ}$ 88.351 avança na matéria e estabelece vinculação da avaliação de impactos ambientais aos sistemas de licenciamento, outorgando ao Conselho Nacional do Meio Ambiente (CONAMA) a competência para "fixar os critérios básicos segundo os quais serão exigidos estudos de impacto ambiental para fins de licenciamento, com poderes, para tal fim, de baixar as resoluções que entender necessárias".

O problema é que a realidade brasileira mostra que existem sérias dificuldades para a implementação da atual política de meio ambiente, inclusive referindo-se à possíveis manobras na legislação ambiental em favor de interesses setoriais. Tal fato pode ser demonstrado a partir da Resolução CONAMA n. ${ }^{\circ}$ 01, de 23/01/1986, por exemplo, que exigia a elaboração de estudos detalhados, em forma de Estudo de Impacto Ambiental (EIA) e respectivo Relatório de Impacto Ambiental (RIMA), para "usinas de geração de eletricidade, qualquer que seja a fonte de energia primária, acima de $10 \mathrm{MW}$ " (Art. 2, inciso XI). Anos mais tarde, a Resolução CONAMA n. ${ }^{\circ} 237$, de 16/12/1997, em seus Artigos 2, 3 e 12, deixava a critério do órgão ambiental licenciador a decisão quanto aos casos em que seriam necessários estudos detalhados ou simplificados, não havendo mais limite de potência e, sim, a consideração, a ser feita pelo órgão ambiental, 
do entendimento de ser o empreendimento "potencialmente causador de significativa degradação ao meio ambiente", ou não. ${ }^{43}$

Posteriormente, devido à crise energética e a necessidade de atender a Medida Provisória n. ${ }^{\circ} 2.152-2$, de $1 \% / 06 / 2001$, a qual trata da implementação de ações emergenciais decorrentes da situação hidrológica crítica, e com o intuito de compatibilizar a demanda e a oferta de energia elétrica, o CONAMA passou, na época, a estabelecer procedimentos para um licenciamento ambiental simplificado, bem como prazo máximo de 60 dias para a tramitação burocrática para a autorização dos empreendimentos com impacto ambiental de pequeno porte, necessária ao incremento da oferta de energia elétrica no país. Tais procedimentos e prazos estabelecidos nessa Resolução aplicam-se, em qualquer nível de competência, aos projetos energéticos de pequeno porte, incluindo:

i) Usinas hidrelétricas e sistemas associados;

ii) Usinas termelétricas e sistemas associados;

iii) Sistemas de transmissão de energia elétrica (linhas de transmissão e subestações);

iv) Usinas Eólicas e outras fontes alternativas de energia. (Resolução Conama n. $\left.{ }^{\circ} 279,27 / 06 / 2001\right)$.

Assim, não é demais, para o propósito de pensar a sustentabilidade ${ }^{44}$ aplicada às PCHs, pensar quais as dimensões desta sustentabilidade, e

\footnotetext{
${ }^{43} \mathrm{De}$ forma complementar, para empreendimentos do setor elétrico, Resolução Conama $\mathrm{n}{ }^{\circ}$ 006, de 16 de Setembro de 1987.

${ }^{44} \mathrm{Em}$ sua curta história, os conceitos de Sustentabilidade e de Desenvolvimento Sustentável (DS) não chegaram a se estabelecer clara e completamente e, em função de suas características, isto talvez não venha a acontecer. A dificuldade de uma definição mais rigorosa desses termos está vinculada ao fato de carregarem consigo uma complexidade de
} 
apontando para qual tipo de desenvolvimento, pois essas são apenas algumas sinalizações de como o discurso desenvolvimentista pode subjugar-se as pressões sociais pela continuidade de um estilo de vida predatório reiterado nas políticas energéticas do País.

\section{4 - Limitações Sócio-Ambientais na Implantação de PCHs}

O movimento ambientalista surgiu a partir da contestação do mundo moderno e de sua lógica de exploração e buscou criar propostas de modelos mais igualitários onde houvesse uma maior justiça social e qualidade ambiental.

Contudo, a pressão da sociedade civil e os requerimentos da política de fomento de energia de modo a garantir condições para que a iniciativa privada venha implementar novas unidades geradoras, de modo que a expansão da oferta de energia possa se dar de forma rápida e eficiente, nessa nova configuração de licenciamento ambiental simplificado, poderá tornar os conflitos de uso local mais problemáticos que outrora: a de reiteração de um padrão de desenvolvimento baseado na exploração

fatores e serem empregados em diferentes níveis de abrangência. Pode-se considerar então, para efeito da análise de uma determinada atividade, as cinco dimensões sobre as quais, segundo, Sachs (1994), baseia-se o DS (ou ecodesenvolvimento, denominação preferida pelo autor):

Sustentabilidade Social: com maior equidade na distribuição de renda e bens;

2. Sustentabilidade Econômica: maior eficiência econômica medida em termos macrossociais;

3. Sustentabilidade Ecológica: melhor uso dos recursos, com limitação de uso daqueles esgotáveis ou danosos ao meio ambiente;

4. Sustentabilidade Espacial ou Geográfica: com a configuração rural-urbana mais equilibrada, com redução de concentrações urbanas e industriais e proteção de

5. ecossistemas;

especificas para o local (Teixeira et al., 1999). 
predatória do meio ambiente e pouca efetividade decisória dos agentes sociais afetados.

Mesmo a energia sendo um ingrediente essencial do crescimento e do desenvolvimento, sua forma de produção pode ser muito prejudicial ao meio ambiente. As usinas hidrelétricas, por exemplo, apesar de não produzirem quaisquer poluentes associados com combustiveis fósseis, interferem pela construção de grandes represas, formação de lagos artificiais e interferência geral sobre os fluxos dos rios. Sem contar a realocação de populações que é problema social de magnitude (Goldemberg, 1988).

Daí, a necessidade de se fazer um Estudo Integrado de Impacto Ambiental, buscando por uma análise profunda da bacia hidrográfica onde a obra será inserida, pois a construção de uma barragem, com a consequente formação da represa, resulta invariavelmente em alterações ambientais, que podem ser de maior ou menor importância, dependendo das características da bacia e da represa, particulamente (Normande, 1994).

Ou ainda, como a matéria-prima da hidreletricidade é a água, da mesma forma como o é de inúmeros sistemas de produção econômica e de preservação da própria vida no planeta (Muller, 1995), sua disponibilidade, em quantidade e qualidade, é fundamental para o desenvolvimento de uma região, pois é um fator que interfere na ocupação e no uso do solo tendo, consequentemente, influência sobre a localização das atividades econômicas dessa região.

Por isso, o licenciamento deve, em tese, ser considerado uma conseqüência do bom e adequado tratamento da questão ambiental e não 
um entrave burocrático. Se os aspectos ambientais forem devidamente equacionados $^{45}$, a implantação do empreendimento deve se refletir em uma garantia ao investidor de que ele não terá surpresas futuras que venham onerar seu orçamento como, por exemplo, uma paralisação temporária ou até definitiva de seu empreendimento, devido ao assoreamento total ou

45 Para o caso de barragens, de acordo com Kleinschmidt in MAIA (1993), com base no estabelecido na Resoluçao CONAMA n. 001/86, recomenda-se que a avaliação de impacto ambiental deva conter: como das condições jurídicas gerais em âmbito federal e estadual;

2. condições básicas do setor e prova da inevitabilidade do impacto, por meio de antecedentes históricos, planejamento e decisões políticas anteriores, da apresentação da situação atual do setor elétrico, da prova da necessidade de uma nova usina frente aos planos estratégicos no que diz respeito à alternativas de produção e de desenvolvimento e da justificativa do local e tecnologia utilizados;

3. descricão do projeto em suas fases de construção e operação, com descrição de todas as partes da obra com potencial impacto frente ao meio ambiente incluindo também processos de construção, a infra-estrutura regional necessária (sistema viário, assentamentos de trabalhadores e técnicos, abastecimento com luz e água, sistemas de tratamento de esgotos, necessidades de lugares de armazenamento de rochas, de materiais de construção etc.);

4. análise de risco de acidentes tanto na fase de construção como de operação, de riscos sociais ligados com os reassentamentos da população atingida incluindo locais para onde será deslocada;

5. descricão dos impactos ambientais do empreendimento benéficos e adversos nos três meios (físico, biológico e sócio-econômico) nas fases de construção, implantação e operação da obra, independentemente de sua localização, bem como efeitos secundários, diretos e indiretos, cumulativos/sinérgicos, temporários/permanentes, imediatos/de médio ou longo prazo, área de abrangência da obra;

6 análise da localizacão definindo e limitando áreas de influência possiveis e locais alternativos, critérios de ponderação e/ou exclusão, especialmente nas áreas de geologia, hidrologia, águas subterrâneas, de espécies em perigo de extinção ou área de proteção permanente:

7. comparação de locais alternativos, potencial de desenvolvimento e planos na sua área de influencia:

8. apresentação dos impactos relevantes;

9. avaliação/ponderação em comparação com a alternativa "zero" e as alternativas tecnológicas ou econômicas anteriormente descritas;

10 medidas mitigadoras resultantes das análises nos itens 5, 6 e 7;

11. restriçōes e dificuldades, com os limites tecnológicos de supervisão de acidentes, bem como dados e conhecimentos ambientais ausentes;

12. relatório de impacto ambiental (RIMA), o qual refletirá as conclusöes do estudo de impacto ambiental em linguagem acessivel ao público, ilustradas por mapas com escalas adequadas, quadros, gráficos ou outras técnicas de comunicação visual, de modo que se possa entender, claramente, as possiveis conseqüências ambientais do projeto e suas alternativas, comparando as vantagens e desvantagens de cada uma delas para a informação do público em geral, bem como servir de base para a audiência pública da AIA prévia;

13

definir e descrever o programa de monitoramento, se for o caso, para obtençăo de dados mais relevantes para a fase de AIA do projeto; 
parcial do reservatório após poucos anos de vida, por ele não ter se preocupado com questões como essa no projeto.

Ou obedecendo a Lei Federal n. ${ }^{\circ} 9.433$ de 1997, buscar sempre o uso múltiplo das águas, por meio de uma gestão integrada dos recursos hídricos com os demais setores usuários visando, inclusive, a possibilidade de diminuir a parcela de investimento aplicada no empreendimento, por rateio do custo total, e maximizar os benefícios nas áreas ambiental, sócioeconômica, energética e outras, na medida em que se pode implantar programas de ações contínuas que estimulem a proteção das águas contra ações que possam comprometer seu uso atual e futuro (Souza e Souza, 1999).

Dessa forma, fazendo um licenciamento ambiental de maneira simplificada, a política ambiental do governo parece ceder à demanda social por mais energia e passa a desconsiderar segmentos titulares de direitos como populações socialmente fragilizadas e demais espécies dependentes dessa base biofísica. O momento negocial democrático e equânime passa a dar espaço para o centralismo decisório.

O nível decisório de construção e operação de qualquer empreendimento deveria, com a participação da sociedade direta e indiretamente envolvida, passar pelo devido reconhecimento da potencialidade e fragilidade ambiental da região frente à especificidade da obra, pois a implementação de qualquer atividade em determinado território acaba por repercutir na dinâmica deste ecossistema. No caso das PCHs, 
embora não se utilizem de volumosas acumulações de água, o impacto causado em sua disponibilidade é um dos mais significativos dentre os problemas gerados, apesar da sua reversibilidade. A ausência de um grande reservatório não deverá causar mudanças indesejáveis na qualidade da água, porém o desvio do curso natural do rio em função da barragem pode ser uma fonte de conflito com outros usos (Mariotoni apud Pacca, 1996).

A diminuição do volume de água em um trecho natural da corredeira causa impacto relacionado com a fauna aquática. Dependendo do trecho atingido pela mudança no regime hídrico e pela sua relevância ecológica no contexto de bacia hidrográfica, pode provocar uma transformação na fauna aquática da região, levando inclusive a extinção de algumas espécies endêmicas.

Um outro tipo de conflito potencial seria o impacto negativo com a população, pela transformação de um local que antes despertava interesse como ponto de lazer e fica com sua utilização comprometida pela diminuição da vazão como, por exemplo, uma cachoeira.

Assim, não é demais, para o propósito de pensar a sustentabilidade aplicada às $\mathrm{PCHs}$, pensar quais as dimensões da mesma a ANEEL deveria atentar e apontando para qual desenvolvimento.

Geralmente, é na transição do plano retórico-discursivo ao plano prático operacional que as dimensões que se possa conceber revelam a 
debilidade social, isto é, revelam uma tensão entre particularismos e as pretensões universalizantes do ambientalismo (Viola e Leis, 1995).

Um claro exemplo disso, foi a Licença Prévia (LP), concedida à CPFL (Companhia Paulista de Força e Luz), com base no Parecer Técnico SMA n. ${ }^{\circ} 7.502 / 90$ e na Deliberação CONAMA $21 / 91$, de $1^{\circ}$ de Junho de 1994 , da Secretaria de Estado do Meio Ambiente do Estado de São Paulo (SMA SP), que aprovou os aproveitamentos de Palmeiras, Anhangüera e Retiro, no rio Sapucaí, no Estado de São Paulo. A Licença Prévia apresentou um conjunto de exigências a serem cumpridas quando da solicitação da Licença de Instalação (LI) como:

- projeto executivo de reflorestamento ciliar;

- projeto de implantação do viveiro;

- levantamento detalhado da fauna;

- programa de reassentamento da fauna;

- programa de resgate da fauna nas fases de limpeza e enchimento dos reservatórios;

- programa de desinfecção de currais e tamponamento de poços. Sem se quer mencionar os possíveis problemas com as populações locais socialmente fragilizadas.

Ora, ao falar de uma $\mathrm{PCH}$, estando, ainda, falando de uma área de influência direta do empreendimento para várias práticas econômicas e extra-econômicas de vários grupos sociais, além, é claro, do uso direto do bem comum, a água para finalidade de suporte à vida - dessedentação de 
animais - e trabalho - a pesca profissional. Em que medida essa dimensão teria sido contemplada pela Licença Prévia?

A decisão sobre os empreendimentos tem sido socialmente excludente e, por detrás dessa exclusão, uma visível hierarquização de usos da água. Assim, quais os fóruns o pequeno agricultor, o pescador de espécies (de ambiente lótico), puderam manifestar o conflito ou sinergia entre os seus interesses e o do empreendedor? Ou, mais uma vez, a "hidrotécnica" foi hegemônica? ${ }^{46}$

Um nível político - institucional que passa a desconsiderar segmentos titulares de direitos - como populações socialmente fragilizadas e demais espécies dependentes dessa base biofísica - merecem ser postas sob crítica. O momento negocial democrático e equânime, no centro de interesses, que serve aos grandes empreendimentos, deveria ser considerado no seu valor intrínsico, quais quer que sejam as quantidades de seres afetados, bem como do seu espaço envolvido.

Com isso, ressalta-se que as ações do Setor Elétrico Estatal e Privado precisam tornar-se parte efetiva de políticas públicas, de estratégias de desenvolvimento das novas empresas privadas e não apenas serem expressão de suas competências nos âmbitos setorial e econômica (Bulcão, 2002).

\footnotetext{
${ }^{46}$ Embora o Código de Águas de 1934 já considerasse a água um bem público, a gestão dos recursos hidricos era considerada uma questão técnica, externa à sociedade, um recurso infinito e de exclusiva competência dos peritos, além do Estado (Guivant e Jacobi, 2003).
} 


\section{4 - ALGUMAS DIMENSÕES DE SUSTENTABILIDADE APLICADAS ÀS}

PCHs: Uma breve descrição a partir de um estudo de caso

\section{1 - Antecedentes}

Tendo em vista a crescente demanda do mercado consumidor de energia elétrica e, à luz das novas diretrizes do setor elétrico, com a participação expressiva da iniciativa privada, a CPFL (Companhia Paulista de Força e Luz) resolveu retomar antigos estudos, visando o aproveitamento global do potencial hidráulico disponível.

Tais estudos remontam do início do século passado, sendo mais sistemáticos a partir da década de 50, onde destacam-se aqueles desenvolvidos pelo Departamento de Águas e Energia Elétrica do Estado de São Paulo (1956); os realizados pela CANAMBRA, integrando o estudo intitulado "Power Study of South Central Brazil" (1963); pelo Consórcio Nacional de Engenheiros Consultores - CNEC em 1977, e os estudos elaborados para a CESP e FIGUEIREDO FERRAZ - Consultoria e Engenharia de Projeto Ltda., concluído em 1987 (Enge-Rio ,1989).

Neste último estudo, de um total de dez aproveitamentos inventariados, oito foram caracterizados como viáveis e, em 1988, foi outorgada à CPFL a autorização para estudos de inventário e viabilidade dos aproveitamentos energéticos do rio Sapucaí, no Estado de São Paulo. 
O rio Sapucaí já tem implantado, ao longo do seu curso, os aproveitamentos de Dourados e São Joaquim, também de concessão da CPFL, e os diversos estudos para o aproveitamento de seu potencial hidroenergético indicaram o trecho compreendido entre os aproveitamentos de Palmeiras, Anhangüera e Retiro como o mais viável e houve aprofundamento dos estudos (Figura 1).

Antes da elaboração do projeto básico, a CPFL contratou, em 1988, a Enge-Rio Engenharia e Consultoria S.A. para a realização de uma Análise Crítica dos Estudos de Viabilidade, juntamente com a própria CPFL. Anos mais tarde, no final de 1999, a ENGEVIX Engenharia S/C LTDA foi contratada para a elaboração de uma revisão completa nos projetos existentes, englobando os serviços de engenharia consultiva para elaboração dos projetos básicos de engenharia e ambiental dos aproveitamentos hidrelétricos, os quais endossaram a viabilidade da construção dos três barramentos do no trecho em questão. 


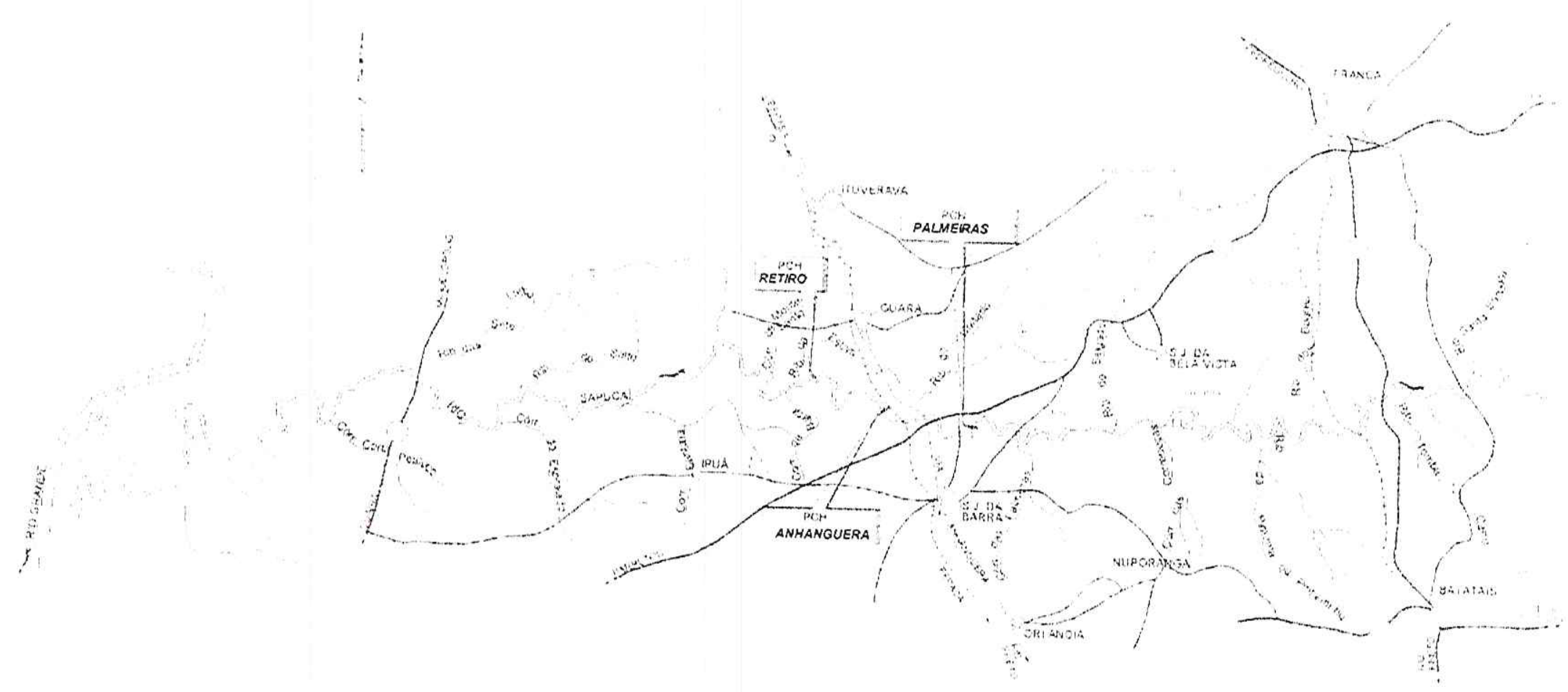

Figura 1: Localização dos aproveitamentos no trecho do rio Sapucai (CPFL, 2001). 


\section{2 - Caracterização sócio-ambiental do local}

\subsection{1 - Localização dos Aproveitamentos e Principais Vias de Acesso}

As UHE's Palmeiras, Anhanguera e Retiro foram previstas para serem construídas no rio Sapucai, no seu trecho entre os municipios de São Joaquim da Barra e Guará, no Estado de São Paulo. A cidade de Ribeirão Preto é a mais importante da região, e foi tida pelos empreendedores como estratégica para ser utilizada como ponto de apoio para os trabalhos a serem executados (Figura 2). 


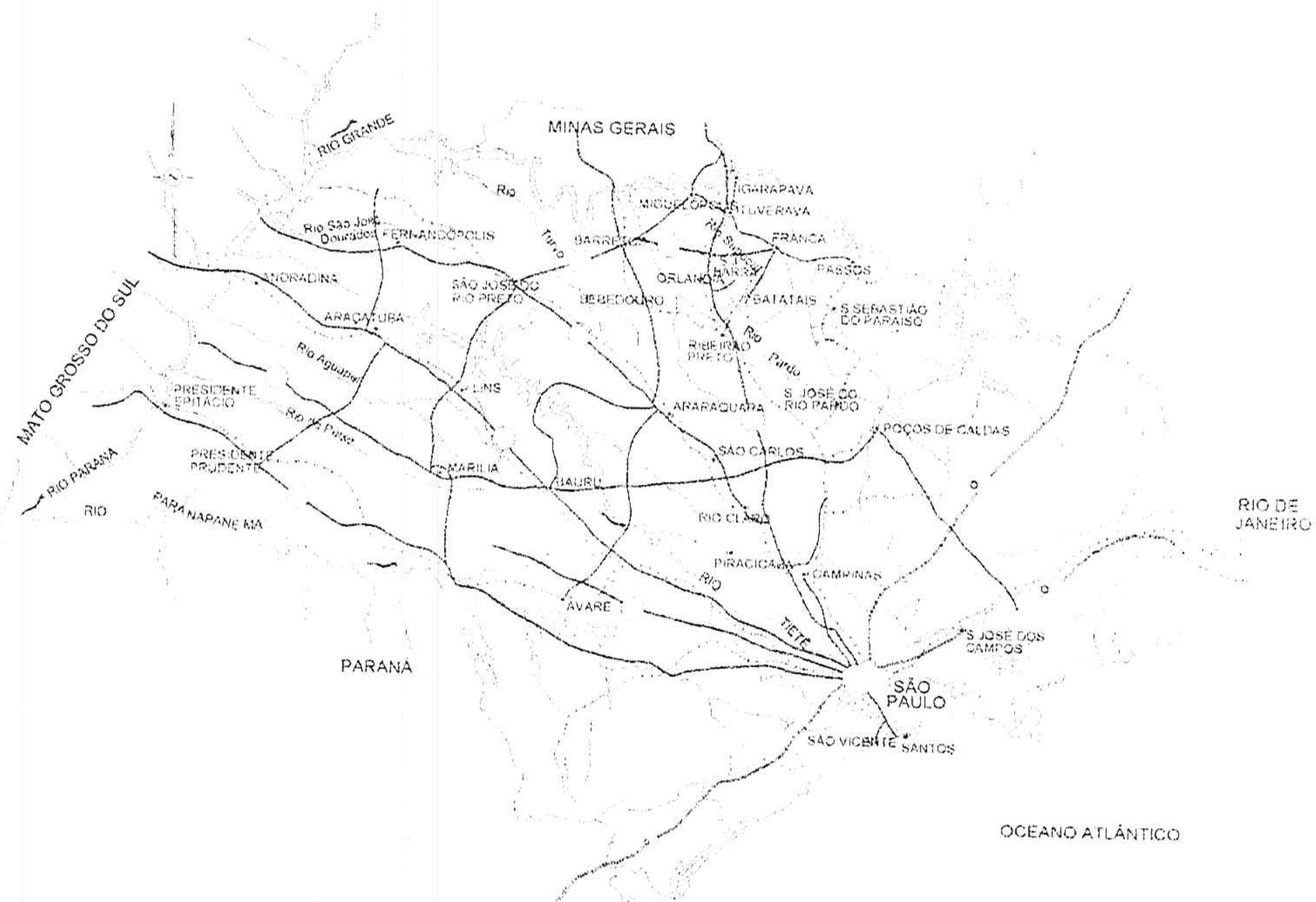

Figura 2: Principais vias de acesso aos empreendimentos (CPFL, 2001). 
As vias pavimentadas mais importantes e próximas aos locais seriam a SP - 330 (Via Anhanguera) e SP - 345 (ligação Franca - Barretos) e os acessos aos locais de cada barramento seriam feitos por caminhos que atravessam propriedades particulares, em geral, canaviais, nos quais poderiam ser construidas estradas ligando cada barramento à via pavimentada mais próxima (Figura 3). "Essas estradas não seriam pavimentadas devendo, entretanto, serem providas dos dispositivos usuais de drenagem, proteção de taludes e serem encascalhadas." (CPFL, 2001).

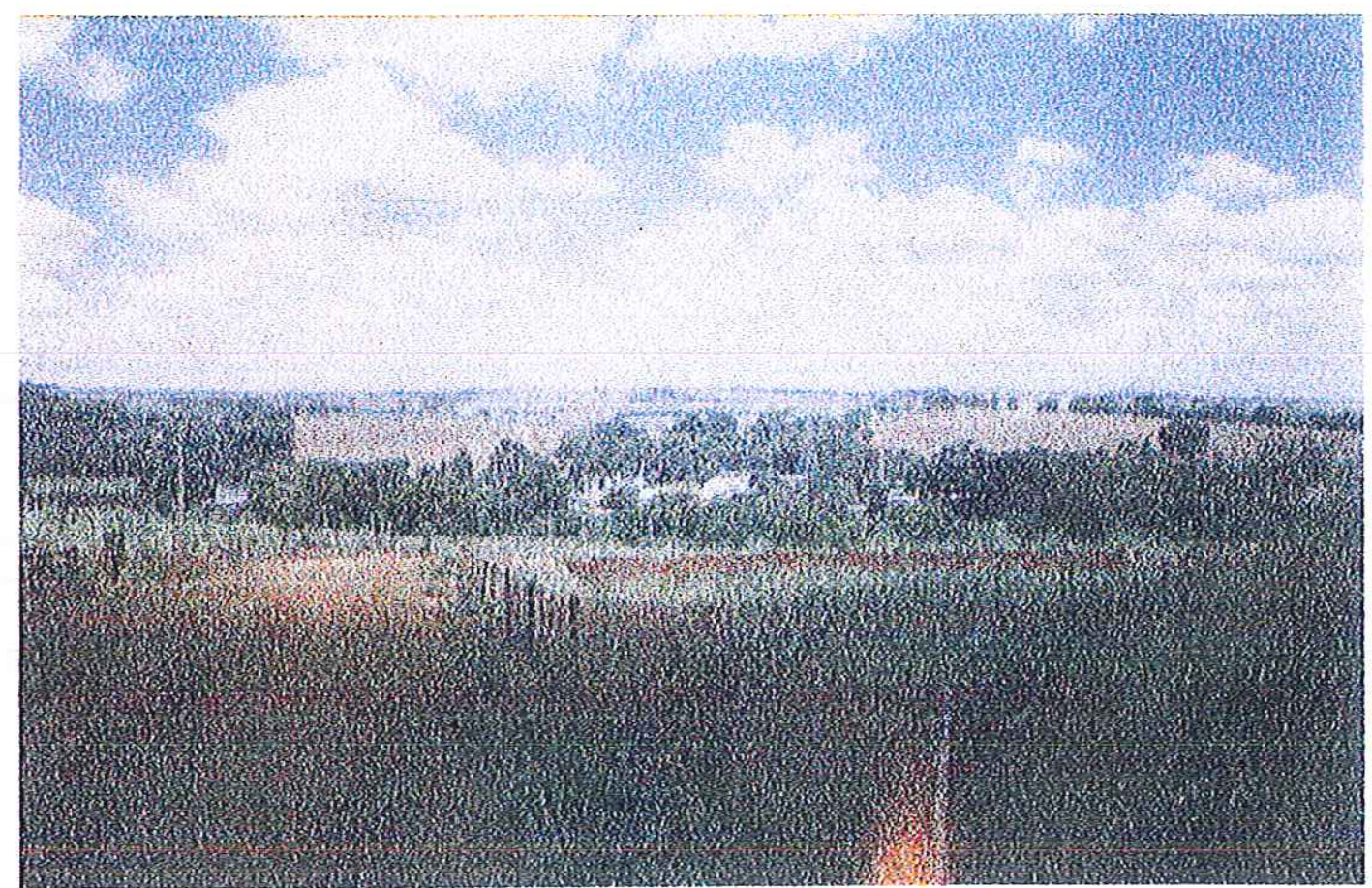

Figura 3: llustração das estradas vicinais que cortam propriedades particulares. 


\subsection{2 - Bacia Hidrográfica}

A bacia do rio Sapucai está localizada a nordeste do estado de São Paulo e tem um comprimento total do rio principal de cerca de $337 \mathrm{~km}$. De acordo com a classificação do DNAEE, esta bacia faz parte da bacia 6 (rio Paraná), sub-bacia 61 (bacia do rio Grande).

O rio Sapucaí é formado pela confluência do córrego da Rocinha com os ribeirões Tomba Perna e Pinheirinho, próximo à divisa dos estados de São Paulo e Minas Gerais, rumando, na direção noroeste até a confluência com o rio Grande, drenando uma área de $6.570 \mathrm{~km}^{2}$ até sua foz. Seus principais afluentes são: o ribeirão Jardim, pela margem esquerda; e os ribeirões Sete Lagoas, da Estiva, Salgado, Santa Bárbara e Fortaleza, pela margem direita (Figura 4). 


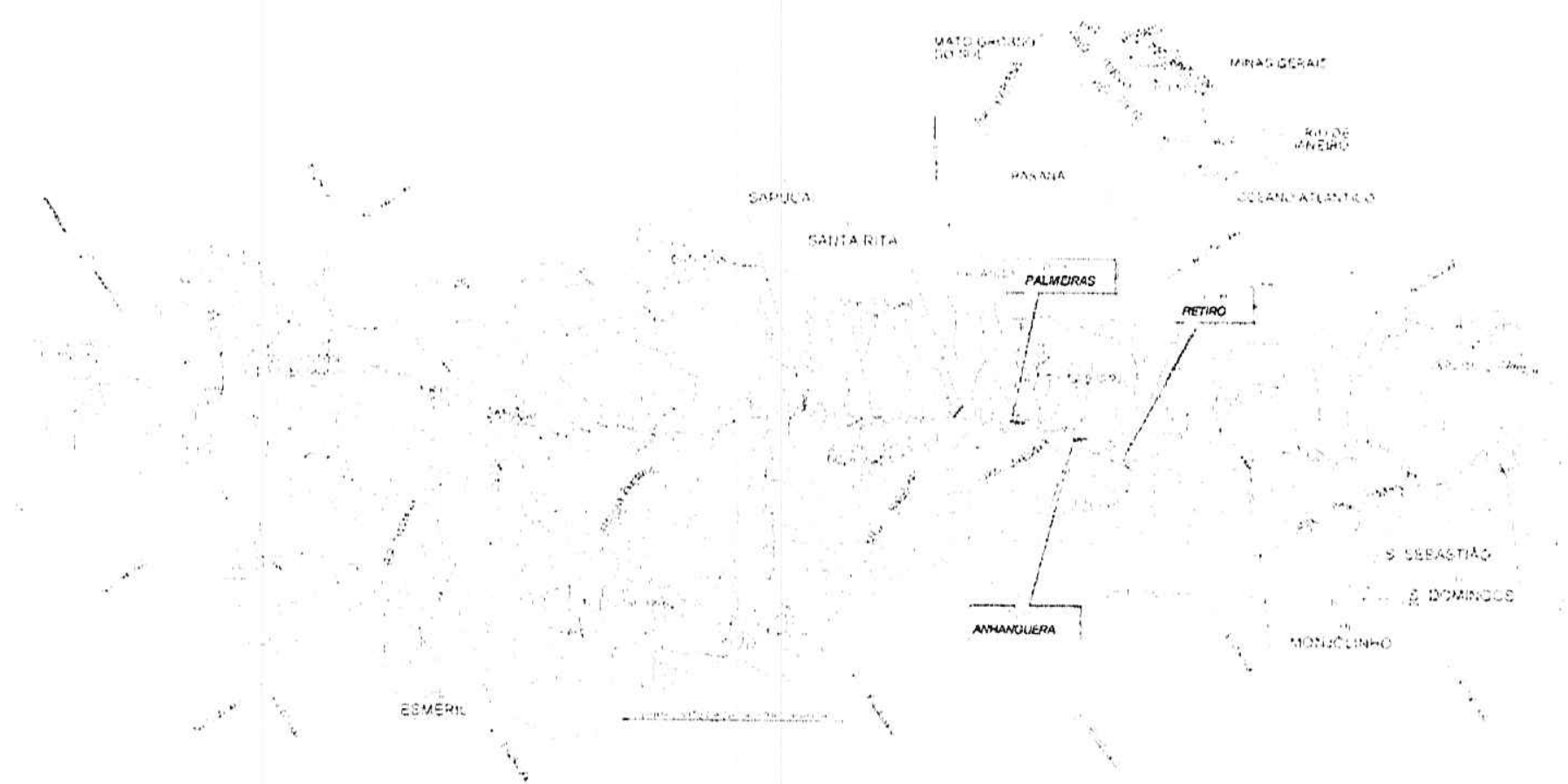

Figura 4: Perfil da bacia hidrográfica do rio Sapucai (CPFL, 2001). 


\subsection{3 - Natureza Geológica e Geotécnica}

A topografia do relevo é suave, onde predomina vale amplo e pouco acidentado. "Devido ao pequeno capeamento do solo, todas as obras ficarão assentes sobre rocha, sendo previsto a remoção do primeiro metro superficial.

Ocorrendo zonas francamente permeáveis, as mesmas deverão ser objeto de análise para a tomada de decisão quanto aos tratamentos a serem adotados." (CPFL,2001).

\section{2 .4 - Geologia}

Esta bacia tem seu eixo dado pelo Rio Paraná, que a divide quase simetricamente e, dentro da referida bacia hidrográfica, predominam rochas do Grupo São Bento, representadas pelas formações Pirambóia, Botucatu e Serral Geral (CPFL, 2001).

\subsection{5 - Geomorfologia}

As unidades do relevo do Estado de São Paulo que compõem a paisagem da bacia hidrográfica do rio Sapucai-Mirim podem ser divididas, segundo aspectos de relevo, altitude, orientação das formas topográficas e processos de sedimentação e erosão, em duas grandes províncias, conforme IPT (1981) (apud CPFL, 2001), em: Cuestas Basálticas e Planalto Ocidental.

As declividades predominantes estão em torno de 12 a $20 \%$, podendo em alguns locais atingir até valores de 20 a 40\%. A erosão laminar do tipo 
severa a muito severa, desenvolve sulcos freqüentes de profundidade média (CPFL, 2001).

\subsection{6 - Pedologia}

Conforme Carta de Solos do Estado de São Paulo (CNEPA, 1960 apud CPFL, 2001), a área da bacia hidrográfica do rio Sapucaí-Mirim no Estado de Säo Paulo engloba basicamente cinco unidades de solos, quais sejam: Litossolo Roxo (76\%), Latossolo Vermelho-Amarelo - fase arenosa (15\%), Litólico - fase substrato basáltico (3\%), Regossolo (5\%) e Hidromórficos $(1 \%)$

\subsection{7 - -}

A paisagem dominante na região do empreendimento compõe-se de um amplo mosaico que alterna cultura de soja e cana-de-açúcar, atravessadas por estreitas matas ciliares.(Figuras 5 e 6). 


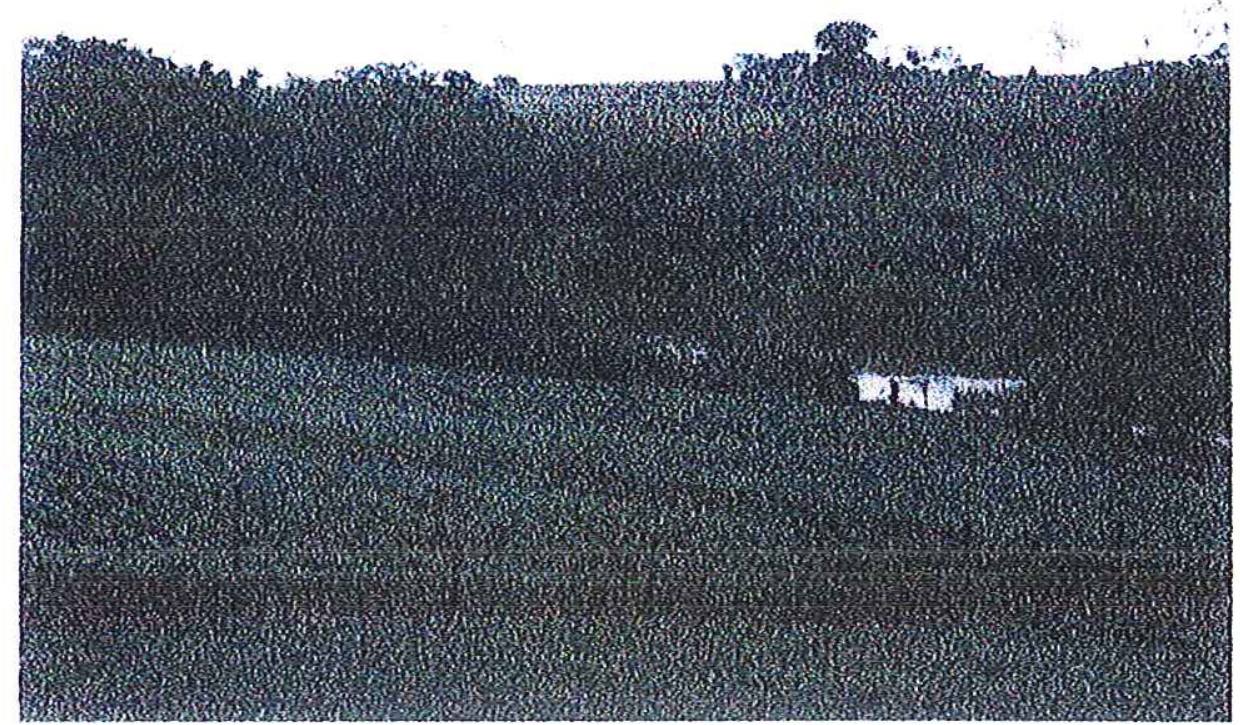

Figura 5: Paisagem dominante da região (CPFL, 2001).

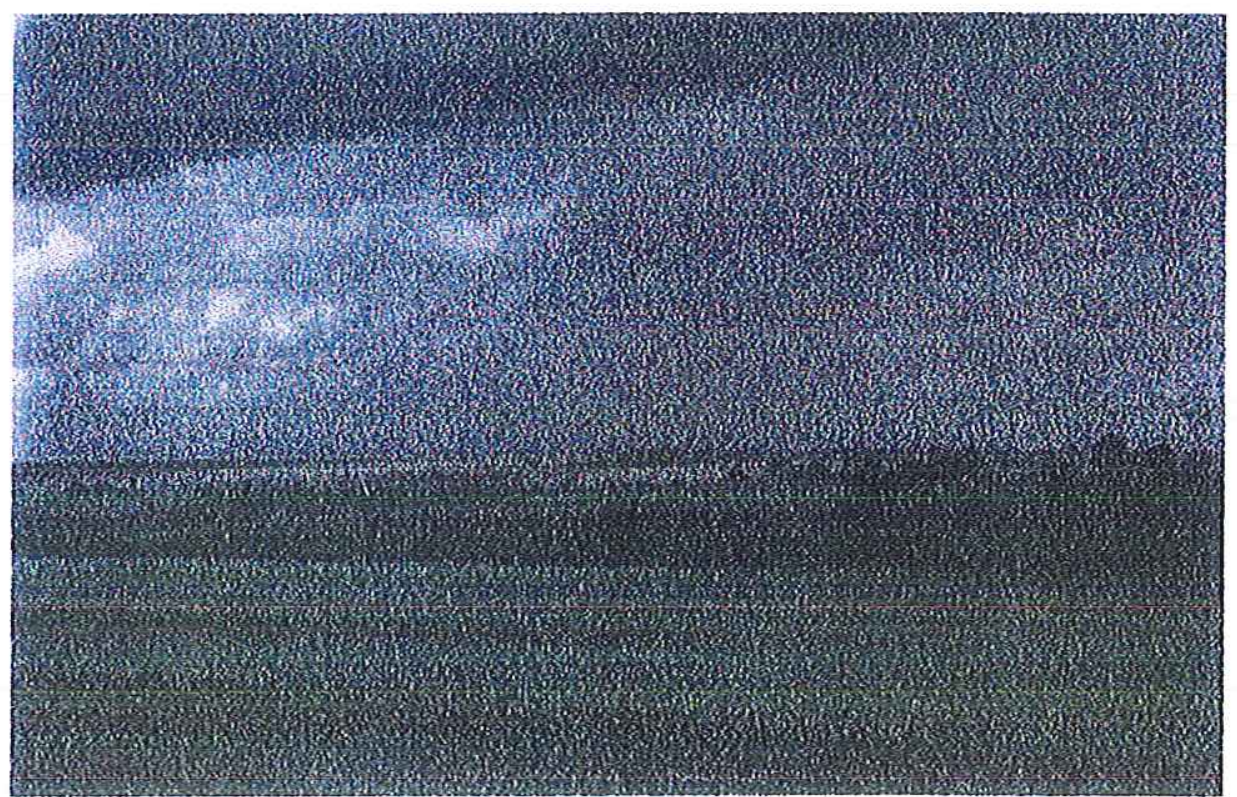

Figura 6: Trechos de mata ciliar intercalados com cultura, próximos ao rio Sapucai (CPFL, 2001). 
4.2 .8 - Uso e Ocupação do Solo

A ocupação do solo da região evidencia sérios problemas de erosão em diversas áreas. Este modelo de ocupação teve como conseqüência a redução drástica da cobertura florestal original ao longo dos anos (Figura 7). 


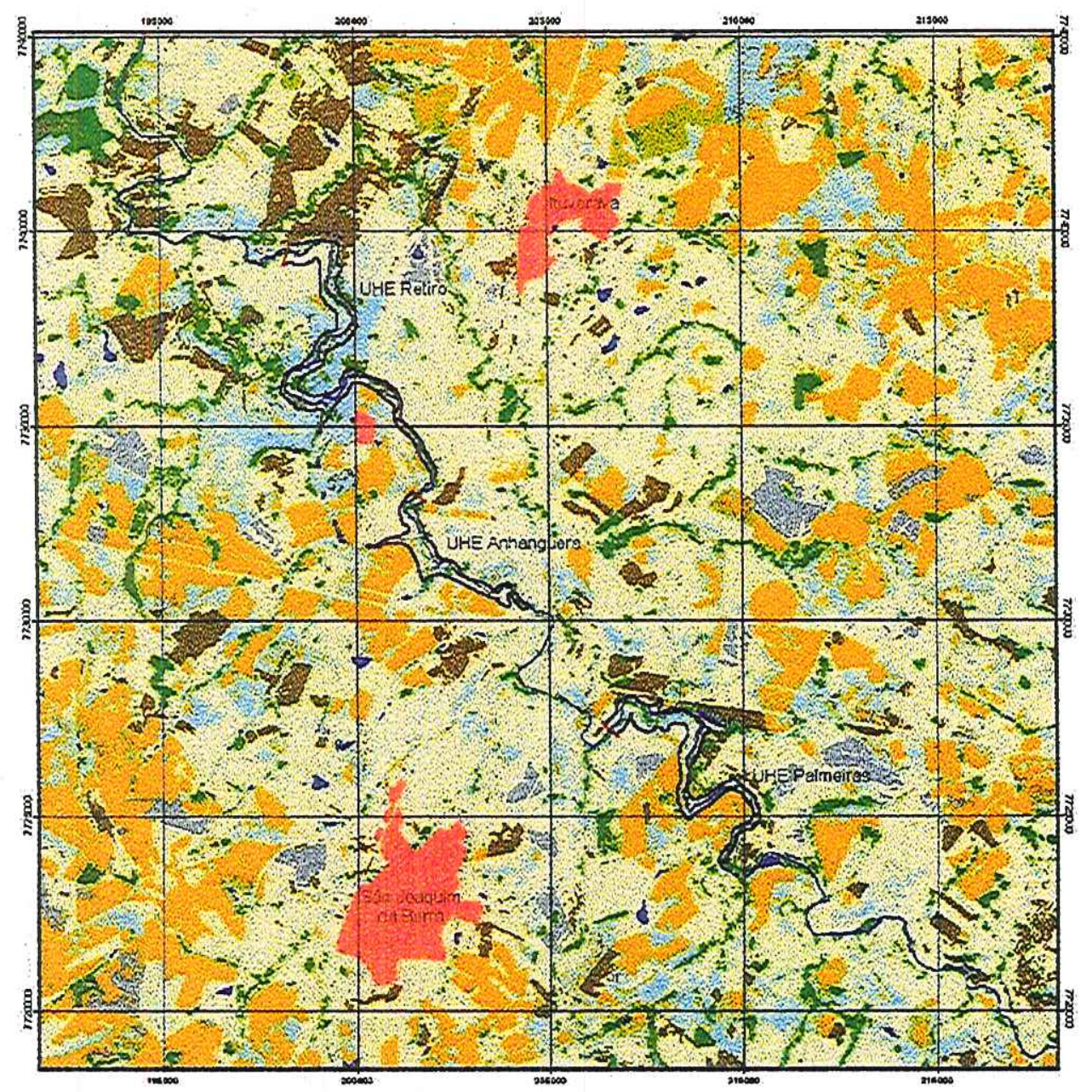

\section{"Uso das Terras \\ C Cobertura Vegetal \\ UHEs Retiro, Anhangü̈era \\ e Palmeiras}

Classiticeçao do imagem Lands 7 ETTM+

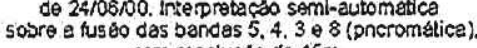

com rasolus 080 co $15 \mathrm{~m}$.

LEGENDA

Remenescentes ficrestais

Pasto sujo $f$ ggroulare em pousio

Agricultura / pestagem

Agrioulture

Agncultura / rellorestamento

Areas quelmados

Solo exposto em área agricola

Area urbana / industria

rios / agudes

Figura 7: Imagem digital do uso da terra e cobertura vegetal das usinas Retiro, Anhanguera e Palmeiras. (CPFL-2001) 
o conseqüente assoreamento dos córregos e rios (e, possivelmente, do futuro reservatório), diminuindo sua capacidade de armazenamento de água (Figura 8) (CPFL, 2001).

A área compreendida pela bacia do médio rio Sapucai encontra-se sob o dominio da região fitoecológica da Savana (Cerrado), predominando áreàs de tensão ecológica entre esta formação e a Floresta Estacional Semi-Decidual e áreas de agricultura cíclica (CPFL, 2001).

As atividades agricolas evidenciadas classificam-se em - reflorestamentos homogêneos (predominando os gêneros Eucaliptus sp. e Pinus sp.), agricultura (predominando culturas de cana-de-açúcar, soja e sorgo) e áreas de pastagens, cobertas por gramíneas forrageiras, comumente mantidas através da queima anual (Figura 9) (CPFL, 2001).

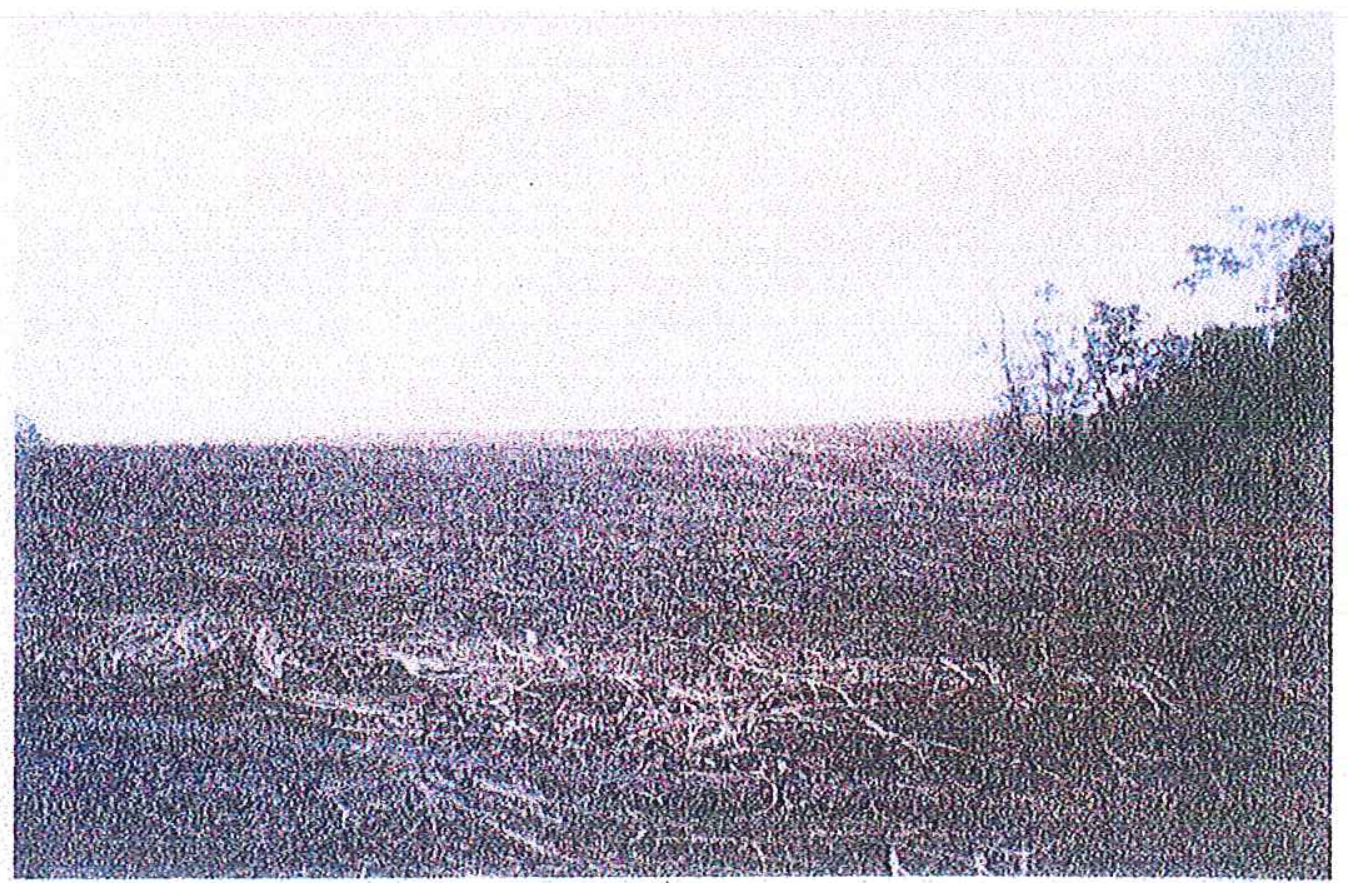

Figura 8: llustração de trechos com a queimada da cana. 


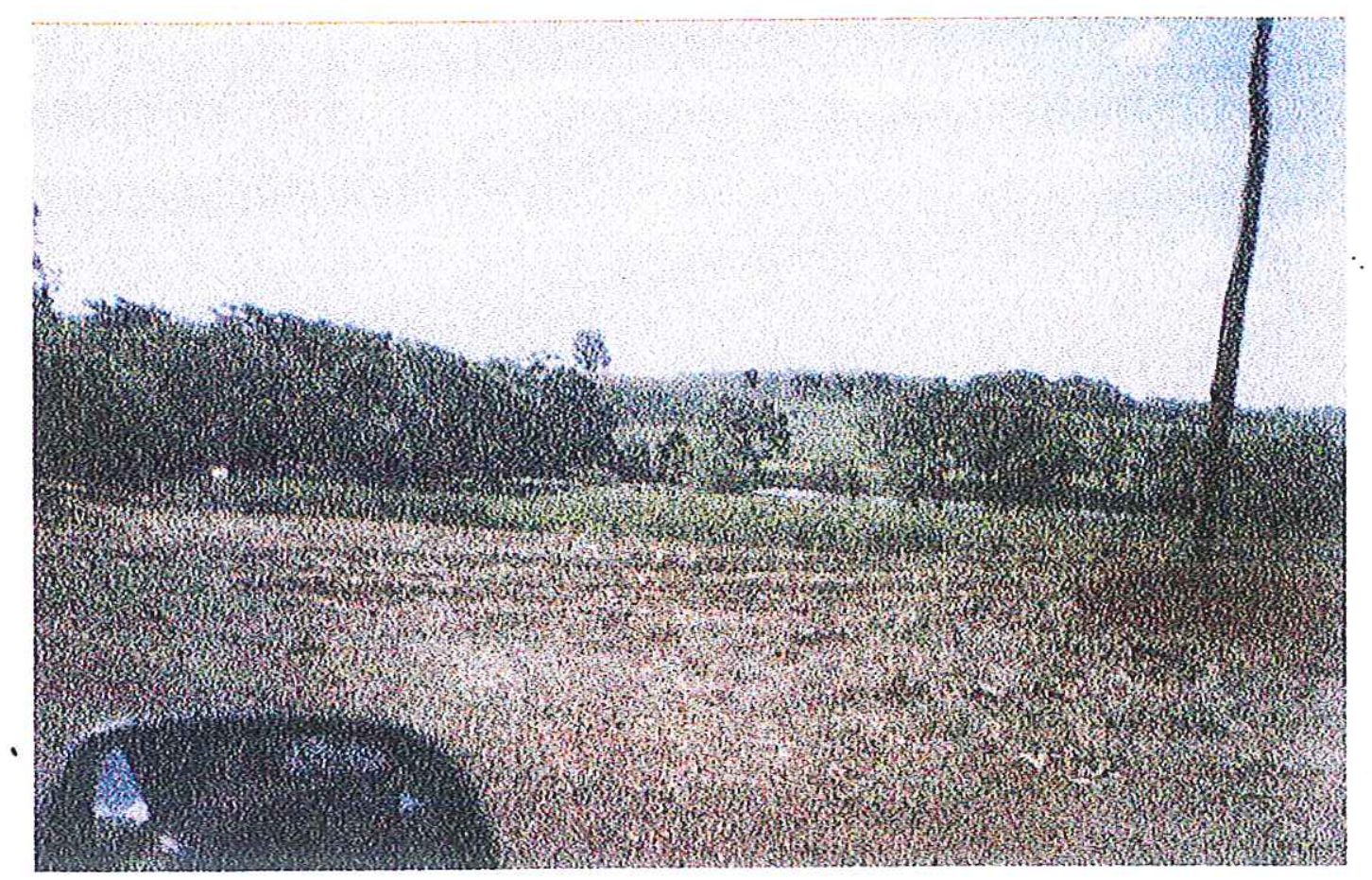

Figura 9: llustração de trechos da estrada vicinal, com a queimada da cana na margem direita, trechos de mata ciliar e o rio Sapucaí ao fundo.

\subsection{9 - Qualidade da Água}

Os padrões de qualidade da água doce são dados pela Resolução n. ${ }^{\circ}$ 20/1986 do CONAMA - Conselho Nacional do Meio Ambiente que, segundo seu uso preponderante, classifica os corpos hidricos em 9 classes. A resolução 20 do CONAMA, estabelece ainda em seu artigo 21, padrões de emissão para fontes poluidoras. Desta forma, o controle da poluição hídrica pode ser feito através de padrões de qualidade do corpo receptor e limitações às fontes poluentes.

A CETESB, órgão responsável pelo diagnóstico de qualidade das águas no estado de São Paulo, tem adotado um índice de qualidade das 
águas (IQA) que incorpora como parâmetros de análise: OD (oxigênio dissolvidos), DBO (demanda bioquímica de oxigênio), coliformes fecais, temperatura da água, $\mathrm{pH}$, nitrogênio total, fósforo total, sólidos totais e turbidez.

Para efeito de análise, a CETESB dividiu o estado em 29 bacias hidrográficas, constituindo o Sapucaí-Mirim e o Ribeirão dos Bagres uma delas. A qualidade da água é acompanhada por 2 pontos de amostragem:

- BA 4002 Ribeirão dos Bagres sob a ponte na Rodovia Municipal que liga SP-334 a restinga;

- SP-2100 Rio Sapucaí-Mirim sob a ponte na Rodovia Franca - Barretos.

O rio Sapucai-Mirim é classificado pela Resolução n. ${ }^{\circ}$ 20/1986 da CONAMA como classe 2, ou seja é um corpo cujas águas destinam-se:

- ao abastecimento doméstico, após tratamento convencional;

- à proteção das comunidades aquáticas:

- à recreação de contato primário (esqui aquático, natação e mergulho);

- à irrigação de hortaliças e plantas frutíferas:

- à criação natural e/ou intensiva (agricultura) de espécies destinadas à alimentação hurnana (CPFL, 2001).

\subsubsection{Aspectos Sociais}

O municipio de São Joaquim da Barra possui, atualmente, uma população estimada em 40 mil habitantes, sendo que $98 \%$ são urbanos e 
$2 \%$ residem no meio rural. No municipio de Guará, a população é da ordem de 20 mil habitantes, sendo $95 \%$ urbanos e $5 \%$ no meio rural (Tabela 1).

Tabela 1: Demografia dos Municipios de Guará e São Joaquim da Barra.

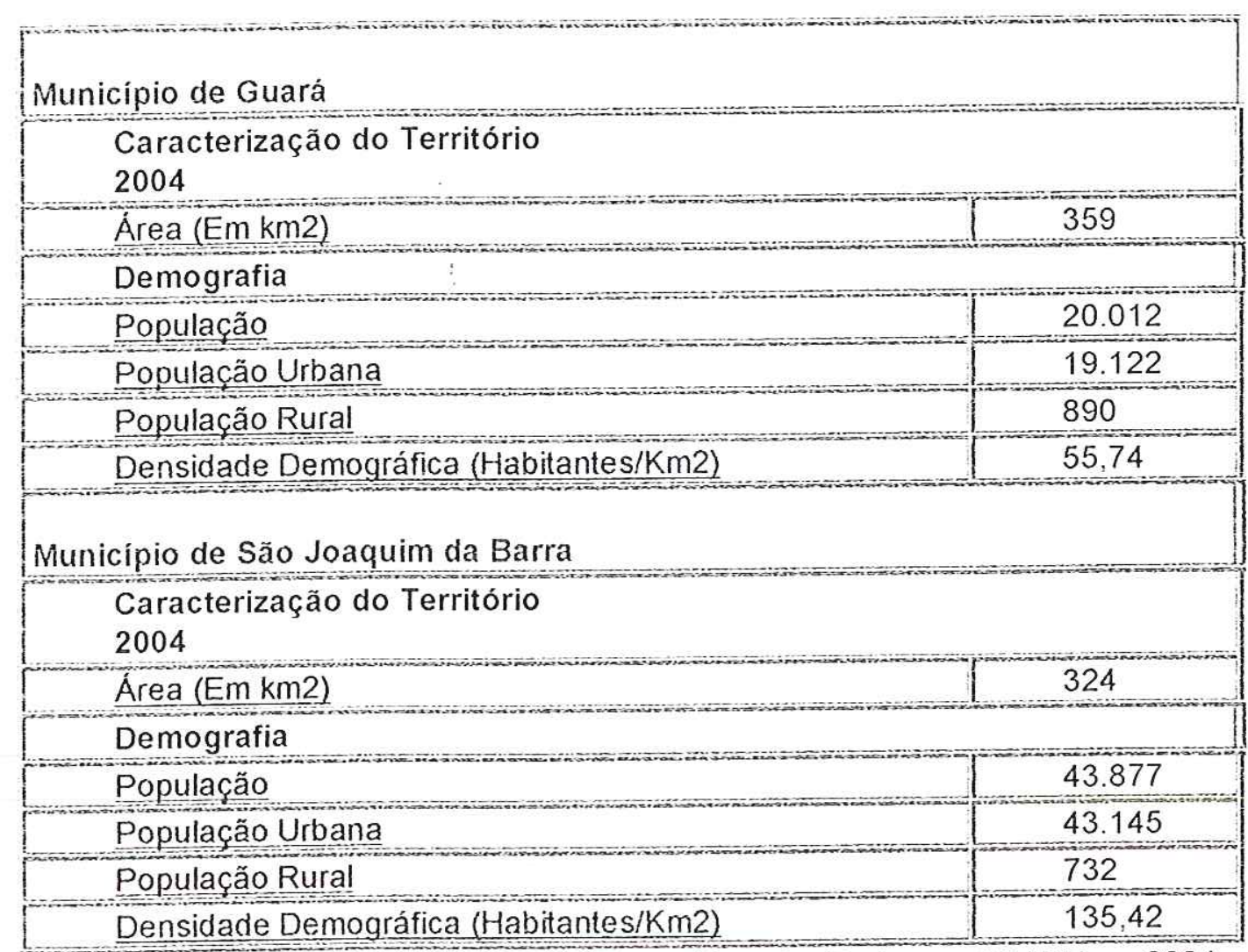

Fonte: Fundação Sistema Estadual de Análise de Dados - SEADE -, 2004. (www.seade.gov.br).

Com relação à atividade econômica, o municipio de Guará possui sua base econômica concentrada na agropecuária, destacando-se em um primeiro plano a pecuária leiteira, seguida pelo cultivo de soja, cana de açúcar e algodão. As propriedades são predominantemente de pequeno e médio porte. 
Já o municipio de São Joaquim da Barra tem a maior atividade centrada nas indústrias de característica regional, com destaque para a alimenticia e a de couro. Em menor escala, estão surgindo outros ramos de indústrias, como a metalúrgica e a de produtos químicos.

Destaca-se também, nos dois municipios, o setor de comércio, confirmando uma tendência que se estende desde o século XVIII.

Com relação à demanda por energia elétrica, São Joaquim da Barra consome cerca de 80 mil MWh/ano e Guará consome 35 mil MWh/ano. Ambos possuem uma rede de distribuição de energia que atende a toda população (Mariotoni, Badanhan, 2001).

\section{3 - Comitê de Bacia Hidrográfica}

Os Comitês de Bacia constituem-se na base do Sistema Nacional de Gerenciamento dos Recursos Hidricos criado pela Lei Federal n. ${ }^{\circ}$ 9.433/1997. Nestes fóruns, são promovidos os debates sobre as questões relacionadas à gestão dos recursos hídricos e são constituídos por representates dos poderes públicos, dos usuários das águas e das organizações civis com ações desenvolvidas para a recuperação e conservação do meio ambiente e dos recursos hidricos em uma determinada bacia hidrográfica.

Dentre seus objetivos, têm-se a gestão participativa e descentralizada dos recursos hídricos naquele território, harmonizando os conflitos, promovendo a multiplicidade dos usos da água e garantindo a utilização 
racional e sustentável dos recursos para a manutenção da boa qualidade de vida e da sociedade local. (www.ana.gov.br)

No entanto, para o caso em questão, o Comitê da Bacia Hidrográfica do Sapucaí Mirim - Grande espera por estudos complementares do Plano Básico realizado pela ENGEVIX Engenharia S/C LTDA (CPFL, 2001) para se manifestar a respeito dos empreendimentos. Tais estudos fazem parte das exigências do Departamento de Avaliação de Impacto Ambiental do Estado de São Paulo (DAIA) para que a concessionária local, detentora da Licença Prévia, receba a Lincença de Instalação dos aproveitamentos. (DAIA Informações Técnicas CPRM/DAIA/008/04 de 10/02/2004) ${ }^{47}$.

\section{4 - Análise dos Aproveitamentos}

Previu-se a PCH Palmeiras com a crista na cota 558,50m, 20m de altura máxima sobre as fundações, $630 \mathrm{~m}$ de comprimento total da crista com o vertedouro, $13,27 \mathrm{~m}$ de queda bruta e 13,60MW de potência instalada, por meio de 02 (duas) unidades geradoras, compostas por turbinas tipo Kaplan Poço.

Já a PCH Anhanguera foi prevista com a crista na cota 542,50m, $16,7 \mathrm{~m}$ de altura máxima sobre as fundações, $460 \mathrm{~m}$ de comprimento total da crista com o vertedeuro, $17,40 \mathrm{~m}$ de queda bruta e 18,50MW de potência instalada, por meio de 02 (duas) unidades geradoras, compostas por turbinas tipo Kaplan "S".

\footnotetext{
${ }^{47}$ Dados obtidos em entrevista com o Sr. Alex, engenheiro do Comitê de Bacia Hidrográfica Sapucai Mirim-Grande, em 05/10/2004.
} 
A PCH Retiro, por seu turno, apresenta projeto com a crista na cota $525 \mathrm{~m} .17 \mathrm{~m}$ de altura máxima sobre as fundações, $415 \mathrm{~m}$ de comprimento total da crista com o vertedouro. $13,18 \mathrm{~m}$ de queda bruta e $14,40 \mathrm{MW}$ de potência instalada, por meio de 02 (duas) unidades geradoras, compostas por turbinas tipo Kaplan Poço.

O nivel d'água máximo de montante da PCH Palmeiras é previsto para ser mantido na elevação $556,00 \mathrm{~m}$, correspondente ao mesmo nivel adotado da viabilidade, o qual seria condicionado pelo nivel de jusante da PCH São Joaquim (Enge - Rio, 1989).

Para a PCH Anhanguera, o nível d'água máximo de montante seria na elevação $540,50 \mathrm{~m}$, aproximadamente $2,0 \mathrm{~m}$ abaixo do nivel máximo normal de jusante da PCH Palmeiras (542.73m) e a PCH Retiro, por sua vez, apresentaria nível d'água máximo normal na elevação 523,00m, quase no mesmo nível de jusante máximo normal da PCH Anhanguera (523,10m), o que demonstra que os empreendimentos foram analisados e discutidos para serem implantados em cascata no trecho entre as PCH's Palmeiras e Retiro (vide Tabela 2). 


\begin{tabular}{|c|c|c|}
\hline \multicolumn{3}{|l|}{ 1. LOCALIIZACAO } \\
\hline RIO: Sapucal & SUB-BAC|A: Rio Grando & BACIA: Rio Parana \\
\hline USSINA PALMEIRAS & USINA ANHANGUERA & USINARETIRO \\
\hline D/stancle da foz: $105 \mathrm{~km}$ & $95 \mathrm{~km}$ & $85 \mathrm{~km}$ \\
\hline \multicolumn{3}{|l|}{ 2. DADOS HIDROMETEOROLOGICOS } \\
\hline Aroe de drenagom do busromento: $4.504 \mathrm{~km}^{2}$ & $4.654 \mathrm{~km}^{2}$ & $4.70 \% \mathrm{~km}^{2}$ \\
\hline Vazbo garantida (95\%): $27.5 \mathrm{~m}^{3} / \mathrm{s}$ & $30 \mathrm{~m} / \mathrm{s}$ & $30 \mathrm{~m} / \mathrm{s}$ \\
\hline Varzaso minime modis mensol: $13,49 \mathrm{~m} / \mathrm{s}$ & $13.49 \mathrm{~m} / \mathrm{s}$ & $14.10 \mathrm{~m}: \mathrm{s}$ \\
\hline \multicolumn{3}{|l|}{ 3. RESERVATORIO } \\
\hline N.A. DE MONTANTE & N.A. DE MONTANTE & N.A. DE MONTANTE \\
\hline MIN. NORMAL: $558.00 \mathrm{~m}$ & MIN. NORMAL: $540.50 \mathrm{~m}$ & MIN. NORMAL: $523,00 \mathrm{~m}$ \\
\hline MAX. NORMAL: $556.00 \mathrm{~m}$ & MAX. NORMAL: $540,50 \mathrm{~m}$ & MAX NORMAL: $523,00 \mathrm{~m}$ \\
\hline MAX MAXIMORUM: $556, \overline{00 \mathrm{~m}}$ & MAX. MAXIMORUM: $540.50 \mathrm{~m}$ & MEX. MAXIMORUM: $523,00 \mathrm{~m}$ \\
\hline N.A. DE JUSANTE & N.A. DE JUSANTE & $\overline{N . A . D E}$ JUSANTE \\
\hline MINIMO: $541 \overline{82 \mathrm{~m}}$ & MINIMO: $523,00 \mathrm{~m}$ & MINIMO: $509.22 \mathrm{~m}$ \\
\hline MAXX NORMAL: $\overline{542,73 \mathrm{~m}}$ & MAX. NORMAL: $523,10 \mathrm{~m}$ & MAX. NORMAL: $508,82 \mathrm{~m}$ \\
\hline MAXX. EXCEPCIONAL $546,50 \mathrm{~m}$ & MAX. EXCEPCIONAL $525,80 \mathrm{~m}$ & MAX. EXCEPCIONAL:SOS.51m \\
\hline AREAS INUNDADAS: & AREAS INUNDADAS: & AREAS INUNDADAS: \\
\hline NON.A. MAXIMORUM: $267 \mathrm{ha}$ & NO N.A. MAXIMORUM: $200 \mathrm{ha}$ & NON.A. MÁXIMORUM: 31 ha \\
\hline NO N.A. NORMAL: 267 ha & NO N.A. NORMAL: $200 \mathrm{hs}$ & NO N.A. NORMAL: 313ha \\
\hline NO N.A. MIN. NORMAL: 267TZ & NO N.A. MIN NORMAL: $200 \mathrm{ha}$ & NO N.A. MIN. NORMAL: 313 ha \\
\hline \multicolumn{3}{|l|}{ 4. BARRAGEM } \\
\hline Cota de criste: $558,50 \mathrm{~m}$ & $542.50 \mathrm{~m}$ & $525 \mathrm{~m}$ \\
\hline Tipo de estrutura: Terra / Enrocamento & Terra / Enrocamento & Terre / Enrocamento \\
\hline Comp. total de crista (com o verted.): $630 \mathrm{~m}$ & $460 \mathrm{~m}$ & $415 \mathrm{~m}$ \\
\hline Altura méxime: $20.00 \mathrm{~m}$ & $16,7 \mathrm{~m}$ & $17 \mathrm{~m}$ \\
\hline \multicolumn{3}{|l|}{ 5. TURBINAS: } \\
\hline Tipo: Kaplan Pogo (2 unikados geradoras) & Kaptan "S"(2 unidades goradoras) & Kaplan Poço (2 unidades goracoras) \\
\hline \multicolumn{3}{|l|}{ 6. ESTUDOS ENERGETICOS: } \\
\hline Quode bruta maxima: $13.27 \mathrm{~m}$ & $17.40 \mathrm{~m}$ & $13,18 \mathrm{~m}$ \\
\hline Potencla do usina: $13,60 \mathrm{MW}$ & $18,50 \mathrm{MW}$ & $14.400 \mathrm{MW}$ \\
\hline
\end{tabular}

Fonte: Adaptado de Ficha Técnica - Projcto Básico (CPFL, 2001). 
Dentre as três usinas, a PCH Retiro seria a que inundaria a maior área (313ha) seguida pela PCH Palmeiras (267ha) e da PCH Anhanguera (200ha). Este fato deve-se às condições do barragem (altura da crista, fundação) e seu "encaixe" na calha do rio.

No entanto, analisando-se o nível da água (N.A.) de montante máximo normal e o nível da água no máx. maximorum percebemos que, entre os dois niveis, o tamanho da área que seria inundada permanece constante. Ou seja, esteja o N.A. no máx. maximorum, correspondente à área a qual poderia ser inundada nas grandes chuvas que costumam ocorrer a cada cem anos, a área de segurança do empreendedor contra qualquer adversidade ao meio antrópico que, eventualmente, queira fixar domicílios ou atividades econômica-sociais nas áreas lindeiras, seria a mesma da área inundada no N.A. normal. E é nessa concepção que esta área acaba compreendendo, segundo o Estado, não apenas o direito, mas a necessidade de cessão da mesma ao empreendedor o qual passa, assim, a ser responsável por sua gestão. Isto é, significa a responsabilidade por não deixar que sejam ocupadas as referidas margens até o limite máximo de eventual inundação que, para os três aproveitamentos, permanece igual a área de inundação do N.A. normal, sendo os principais impactos sócioambientais referente aos três aproveitamentos apresentados na Tabela 3 e ilustrados na Figura 10 à seguir: 
Tabela 3: Impactos Sócio- Ambientais referente aos três aproveitamentos.

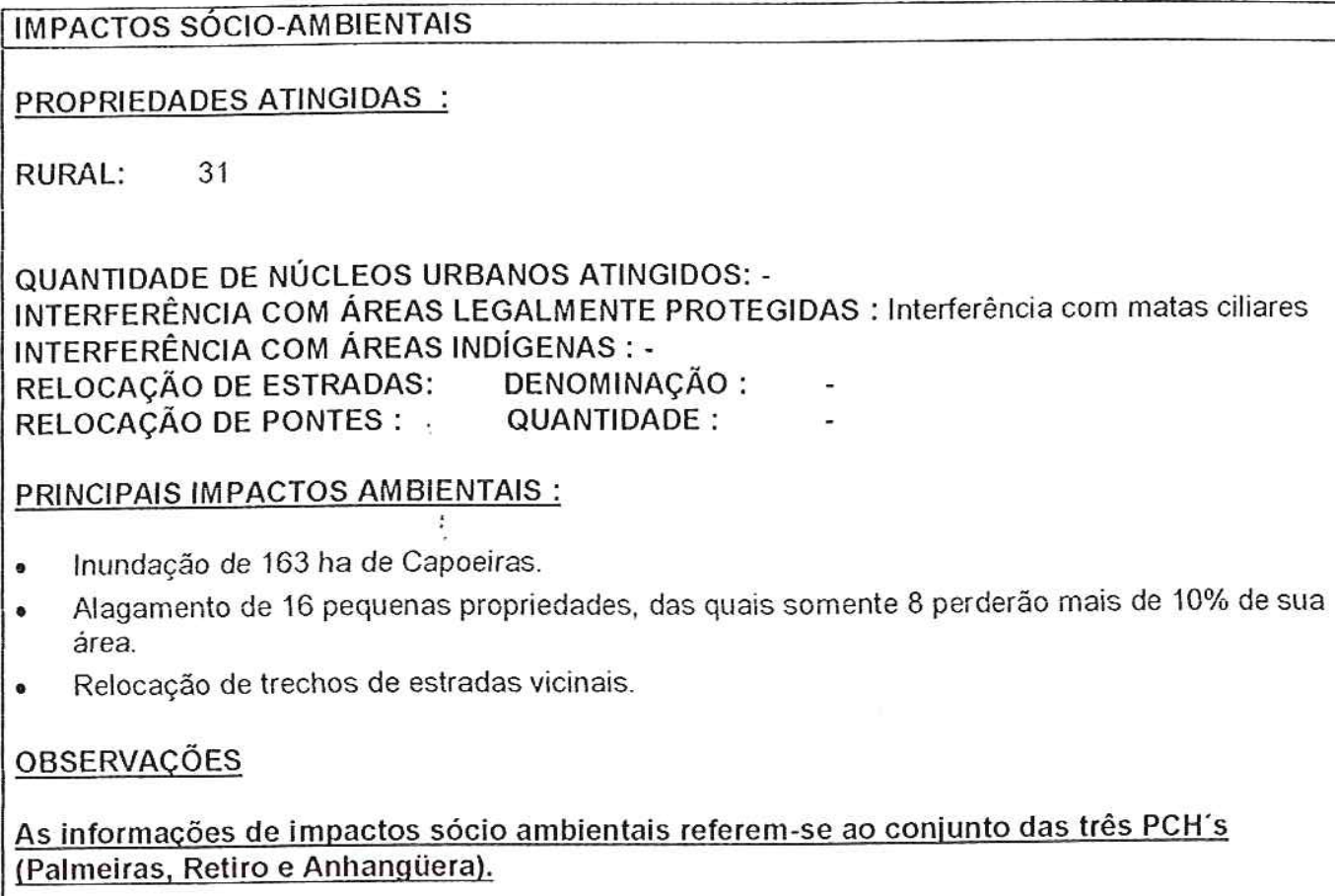

- Alagamento de 16 pequenas propriedades, das quais somente 8 perderão mais de $10 \%$ de sua àrea.

- Relocação de trechos de estradas vicinais.

OBSERVAÇÕES

As informacões de impactos sócio ambientais referem-se ao conjunto das três PCH's (Palmeiras, Retiro e Anhangüera).

Fonte: Adaptado da Ficha Técnica do Relatório Final do Projeto Básico da PCH Anhanguera- 8574/GE-10-RL-2001-1 - (CPFL, 2001). 


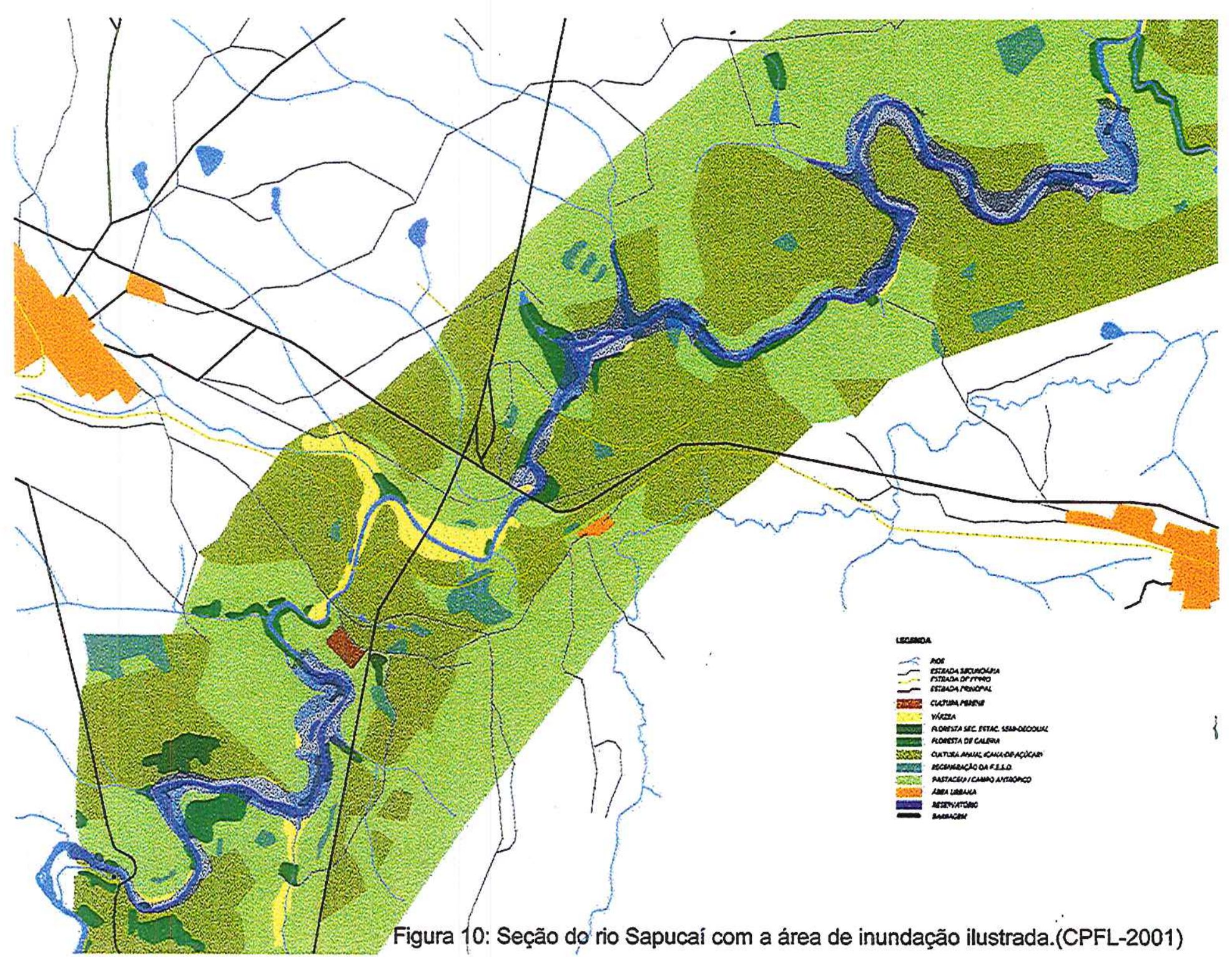


A melhor forma de analisar, sob o prisma sociológico, o impacto das referidas obras é observar como as mesmas consideram o potencial de desenvolvimento da região frente as atividades já exercidas e os planos futuros para a área de influência dos aproveitamentos, perpassando por uma análise de risco de acidentes nas fases de construção e operação das usinas, incluindo os riscos sociais ligados com os reassentamentos da população atingida e os locais para onde devem ser deslocadas e as medidas mitigadoras previstas.

Apesar dos vários estudos indicarem pela viabilidade dos três empreendimentos, ao menos nas questões econômicas estritas ao projeto e de engenharia, a sua implantação nas circunstâncias de privatização e descentralização do setor elétrico nacional, aliada aos novos atrativos institucionais e econômicos, traz à tona que as tendências concentracionistas e centralizadoras do capitalismo na contramão da Democracia.

Senão, apesar dos dois muncicípios (São Joaquim da Barra e Guará) possuirem uma rede de distribuição de energia que atenda a toda população ali inserida, as PCHs visam aproveitar os recursos locais para o oferecimento de serviço no nivel regional. O propósito de levar a produção à rede através do sistema interligado nacional acabou, novamente, "privilegiando os espaços de produção em detrimento do espaço de vivência, institucionalizando a economia como regra universal, transformando-a em lei e invadindo todos os domínios do ser e os modos de vida das pessoas" (Leff, 2003).

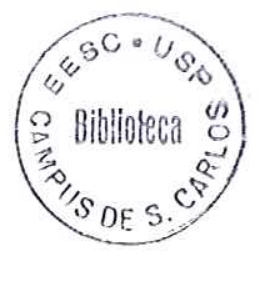


Nesse sentido, embora a água continue sendo um bem público, o que tem se verificado no Brasil é a utilização dos corpos d'água mais extensos com priorização como matriz energética (Jacobi et al.. 2004).

Entretanto, seguindo uma tendência internacional estimulada pelos graves problemas na quantidade e qualidade da água disponível no planeta, ocasionados pela forma em que foram geridos durante, principalmente, o decorrer do século passado, a Lei Federal 9.433/1997, que instituiu no Brasil a Política Nacional de Recursos Hídricos e criou o Sistema Nacional de Gerenciamento de Recursos Hidricos, trouxe inovações significativas. No texto desta lei, a água deixa de ser considerada exclusivamente uma questão técnica, externa à sociedade, um recurso infinito e de exclusiva competência dos peritos. Para tanto, a legislação propõe uma politica participativa e um processo decisório aberto aos diferentes atores sociais vinculados ao uso da água, dentro de um contexto mais abrangente de atribuições do Estado, do papel dos usuários e do próprio uso da água (vide Quadro 3) (Guivant e Jacobi, 2003). 
QUADRO 3: Breve caracterização dos principais aspectos da legislação

brasileira sobre recursos hídricos (Guivant e Jacobi, 2003).

1. A água é um bem de domínio público;

2. A água é um recurso natural limitado, dotado de valor econômico (atualmente pagamos pelo serviço de distribuição da água, porém, não pelo líquido em si);

3. Em situações de escassez, o uso prioritário dos recursos hídricos é o consumo humano e a dessedentação animal;

4. A gestão dos recursos hídricos deve sempre proporcionar o uso múltiplo das águas;

5. A bacia hidrográfica é a unidade territorial para a implantação da Política Nacional de Recursos Hídricos e atuação do Sistema Nacional de Recursos Hídricos. Com este item a lei rompe com as tradicionais fronteiras físicopolíticas dos estados, exigindo uma integração com os poderes municipais, estaduais e federal, especialmente quando se trata de uma bacia de rio federalizados (Assis, 1998);

6. A gestão dos recursos hídricos deve ser descentralizada e contar com a participação do Poder Público, dos usuários e das comunidades. Estes farão parte dos Comitês de Bacia, que têm entre suas responsabilidades a de promover debates das questões relacionadas aos recursos da bacia, a arbitragem, em primeira instância administrativa, dos conflitos relacionados à Recursos Hídricos e a aprovação e acompanhamento da execução do Plano de Recursos Hídricos da bacia, além de estabelecer critérios e promover o rateio de custos das obras de uso múltiplo, de interesse comum ou coletivo (Assis, 1998);

7. A gestão sistemática dos recursos hídricos, sem dissociação dos aspectos quantidade e qualidade;

8. A adequação da gestão dos recursos hídricos às diversidades físicas, bióticas, demográficas, econômicas, sociais e culturais das diversas regiões do País;

9. A integração da gestão dos recursos hídricos com a gestão ambiental;

10. A articulação da gestão dos recursos hídricos com a do uso do solo;

11. A articulação do planejamento de recursos hídricos com os setore usuários e os planejamentos regional, estadual e nacional;

12. A integração da gestão das bacias hidrográficas com a dos setores estuarínos e zonas costeiras;

13. Os dados e estudos básicos são as peças mais importantes ao processo de tomada de decisão.

Não obstante, não são os princípios prescritos na referida politica que nos deparamos ao analisar o caso das três usinas. Em visita às cidades de Guará e São Joaquim da Barra, quando indagados sobre a possivel implantação de três novas usinas na área, difícil encontrar alguém entre a 
população local que soubesse algo a respeito, a não ser nos casos em que fossem diretamente atingidos como, por exemplo, terem parte de suas propriedades atingidas pela inundação. A divulgação, necessária por lei, não chegou à população.

"Não, não "tamu" sabendo de nada não(...)eu tô ouvindo fala nisso só agora...seria bom divulgá sim, pra se interá do assunto..." (sr. Carlos, morador do municipio de SJB)

"Não tô sabendo de nada, nada. E como a gente não sabe do que se trata este probrema não sabe nem assim, vamo supor, responder no momento.

(...)É muito ruim né, era pra eles estarem informando tudo certinho. mas não teve nem panfleto na cidade, não aconteceu nada. Não aconteceu nada até agora." (sr. Marcos, morador do município de SJB)

"Eu tô sabendo mais ou menos, mas isso era bom você ir falar lá com os políticos, vereador, prefeito que eles vão poder te informar (...) Ah, eu fico sabendo que tem um amigo que tem um rancho lá na bera do rio, então disse que ia inundá, né? Então o pessoal tá falando. (amigo interrompe- Então vai inudá tudo?) Vai, vai, vai alagá, mais é uma usina diferente das outras. porque eu ainda não sei quem é que vai tocar mas pelo jeito é a CAMARGO ${ }^{42}$, então porque ali não é que 48" Primeiro, a CPFL era detentora de uma LP (licença prévia) e do direito de construir antes
da privatização. Quando foi privatizada ela herdou esse direito. mas a ANEEL, quando da
sua fundação e regulamentação, extinguiu esses processos, o que levou novamente a
entrar em disputa em 2001 onde a SEBAND LTDA. (Sociedade de Energia Bandeirantes)
solicitou junto à ANEEL, o direito de se apresentar. o que lá na ANEEL é chamado de
condição de ativa, ou seja, você solicita e ela libera os eixos para qualquer interessado que
se apresentar e apresentar o projeto básico. Se for aprovado, ela concede o direito de
exploração (concessão). Entäo, a SEBAND solicitou estas três e foi considerada ativa, 10
dias depois a CPFL correu lá, e solicitou também e ela também foi considerada ativa. A
partir daí, abriu um prazo de 120 dias para que os remanescentes que estivessem também
em condições de ativo apresentassem os seus respectivos projetos para que a ANEEL
julgasse o vencedor. Ambos foram considerados válidos. tanto o projeto apresentado pela
CPFL quanto o projeto da SEBAND, mas existe um critério de desempate que é o artigo 18
da resolução 395 que diz que o sujeito. no critério de desempate. será considerado
vencedor, o que não for distribuidor na área de concessäo. a CPFL é (Usina São Joaquim)
e o que tiver maior parte da área a ser envolvida no empreendimento, ou seja. terem
propriedade ou feito aquisição ou ter uma parceria com os proprietários. Entäo, esse tipo de
critério de desempate levou a Sociedade de Energia Bandeirantes - SEBAND LTDA.- a 
nem essas usina que inunda tudo, porque se for fazer pra inundá tudo inunda pra cá. Mas ela é individual.

Entrevistador - É vão ser três usinas ...

Gusmão- Por isso que ela é bom, mas parece que não é três é quatro. Por isso que era bom você ir conversa com essas pessoas. Se você for na prefeitura depois do almoço eles te passam." (sr. Gusmão, morador de São Joaquim da Barra).

Entrevistador- Eu queria saber qual é e como este processo está sendo feito em relação à audiência pública, ela tem sido feita? A comunidade tem sido... A gente andou perguntando aqui pela cidade e que..., e a população não está muito a par disso daí, então, como tem sido noticiado? A população está a par ou só serão avisados quando começar a inundar?

João - Não, não...não... isso foi extensivamente em São Joaquim, me estranha até essa colocação sua, que o pessoal diz não saber.

(...) É, isso sim, mas veja bem, lá traz antes da CPFL ser privatizada, ela já tinha chegado até a efetuar uma concorrência para quem construiria, conseqüentemente, já tinha sido feito a audiência pública, nos eixos, já foram motivos de audiência pública, posteriormente com a mudança da lei eh... entenderam que, basta, a própria secretaria do meio ambiente, entendeu que bastaria reunião pública, não audiência. Então foi feito reunião pública aqui na Câmara Municipal noticiada em dois jornais de grande circulação do município, rádio, eu mesmo já concedi meia dúzia de entrevista, nunca me furtei, então me estranha essa colocação do desconhecimento da população, agora, que tem pessoas que não ouve rádio que não lê jornal, eu não posso responder por isso. Se você perguntar para qualquer vereador aqui ele sabe das usinas, se você perguntar ah..., a nível de rádio, jornal a própria imprensa, vão saber porque já noticiaram com extensa páginas, números de páginas. comentando a respeito e tomamos o cuidado, como esse rio é um rio federal, mas que na nossa região

vitória, então nós já estamos outorgados descle 2002." (João Mattaraia, vice-prefeito de SJB e representante local da SEBAND em entrevista 24/07/2004). 
estão envolvendo duas comunidades, São Joaquim da Barra e Guará, ah... nós também entendemos que se faria necessário fazer uma reunião pública também em Guará e nós resolvemos fazer reunião pública, no tocante a explicar o que seria o empreendimento aqui em São Joaquim e quando envolver a parte de desapropriação. nós faríamos em Guará, como foi feito. Então, hoje tem documentado em jornal, a maioria só pra você ter uma idéia na reunião pública envolvendo proprietário nós tivemos na lista de chamada quase 150 nomes de proprietários e/ou interessados; de proprietários nós tivemos quase $90 \%$ de adesão a reunião. então,tiveram lá presentes, primeiro porque era de interesse deles. (sr. João Mattaraia, vice-prefeito de Săo Joaquim da Barra e representante local da Sociedade de Energia Bandeirantes - SEBAND).

Nena- Em Guará foi feita[ a audiência] mesmo mas não tinha todo mundo, ele não tava especificando nada além disso, nós do condomínio, não ficamos sabendo nada do que ele ia se feito da fauna e da flora, então ele não pode assim chegar, ele não deu projeto, de locação para o pessoal que tem rancho, não deu uma área definida pra nós, de indenização propôs um valor absurdo, tem pessoas que estão sendo lesadas... (sr. Nena, morador de SJB, líder dos rancheiros e proprietários de um dos ranchos do condomínio que será inundado)

Valter -: isso ainda não foi discutido com a sociedade, isso ai geralmente convocam um número de pessoas e divulgam, mas năo é uma divulgação ampla, você não vê o interesse, primeiro que a população enquanto não viu o resultado e o dano, não vai se manifestar, porque é aquela história, desconhece, né? o desconhecimento leva as pessoas às vezes à omissão

(...) eu acho que isso teria de ser debatido pela sociedade e até pelo próprio prefeito, Edson Joaquim, a outra parte do Guará, mas veja bem eu acho que deveria discutir com a sociedade, e ver o que a sociedade entende e isso até no plebiscito, porque a democracia é isso através do voto para as pessoas se manifestar porque é lógico que existe dois lobs, o lob empresarial que quer instituir e realmente visa lucro e ninguém vai montar uma usina em sã consciência pra ser deficitário de si mesmo, quem está montando está vendo a sua parte comercial e também existe o outro lado também que é os funcirnários e pessoas que vão 
passar pelo desemprego. mas precisa ver se realmente isso se faz por juslo na cidade às vezes abrir mão de algumas coisas. eu acho que isso deverla ser debatido na sociedade. mas pelo jeito que eu tô vendo, isso é uma decisăo que vem de cima, né? Eu não vejo ela como um município pudesse impedir, pruneiro que a outorga é federal. a legislação do meio ambiente é estadual, năo te do município. Quer dizer o município não autoriza nada. quem autoriza, é..., a outorga a constituição é o governo federal. e quem dá as regras da legislação do meio ambiente é o estado. quer dizer, o município, a participação dele nesta decisão, vamo dizer não é nem mínima, ela nem existe. (sr. Valter Martins, vereador e presidente da Câmara dos Vereadores de São Joaquim da Barra)

Isso demonstra a falta de informação junto à população local Há portanto, uma violência simbólica, camuflada por um discurso técnicocientífico que está distante do conhecimento cotidiano. A populaçär), em parte, assimila as informações e nela confia sem questionar, reveland', uma forte apatia diante dos fatos. Ou, informações como boatos, especuliç̧ões, distorcidas.

Diante deste problema, em contraposição às recomendações løgais, ficou evidenciado a limitação da divulgação da mesma, uma vez qu: atingiu somente uma minoria daquela cidade. Isto fica claro na fala dr: uma senhora, que expõe um grupo que ficou excluido das informações a rs:speito das usinas.

"...lá na rádio São Joaquim a turma de São Joaquim da Barra não pega rúd'lo, eles pegam a região, os jovens não gostam de ouvir rádio. Então na rádio Sär, Joaquim saiu. (...) mas os jovens pegam mais a rádio Pan, rádio TV". (sra. Marlene, moradora de São Joaquim da Barra). 
Também evidencia a falta de sustentabilidade social e cultural destas políticas. Não só por não dar condições para o pleno e livre arbítrio da comunidade local em opinar a respeito das obras e dos valores culturais passiveis de serem afetados, em virtude da falta de uma relação dialógica/comunicativa entre os diversos segmentos sociais envolvidos, buscando por soluções específicas a partir do instrumental cultural da população afetada e do seu entorno mas, por ir contra à premissa existente no discurso atual de democracia participativa, bem como estar bem longe do capítulo 40 da Agenda 21 que afirma que "todo individuo é simultaneamente gerador, provedor e usuário de informação, incluindo dados, informações e experiências" (Secretaria do Meio Ambiente, 1994 in Furnival e Costa, 2003, p.66).

Dessa forma, percebe-se que as decisões políticas são realizadas diante de uma atitude autoritária e hierarquizada, eminente da ação do poder público e do poder privado, os quais excluem as opiniões populares dos momentos decisórios, apenas informando-os de suas resoluções. Tal exclusão e parcialidade, além de por em risco a cidadania, deixam poucas esperanças quanto à possibilidade de gerar processos sustentáveis de desenvolvimento social e tecnológico (Furnival e Costa, 2003, p. 63).

"(...) o empreendimento vai ser feito, uma... um... decreto de, tornando de utilidade pública para fins de desapropriação...(...) eu acredito que...a...a... a não concordância com o valor não impediria, na minha humilde maneira de pensar, não impediria situações de execução da obra, depois se não concordar com o valor, é uma questão judicial que assim que o juiz deliberar a respeito disso, se for a menos a SEBAND teria cumprido e ser for a mais tem que voltar a diferença." (sr 
João Mattaraia, vice- prefeito de São Joaquim da Barra e representante local de SEBAND)

João Mattaria, vice-prefeito e representante local da Seband (Sociedade de Energia Bandeirantes) comentando a respeito do Decreto n.o 2003, de 10 de Setembro de 1996, o qual atribuiu ao produtor independente ou autoprodutor tal benefício. Conforme o Art. 30 deste decreto, a requerimento justificado do interessado, o poder concedente pode declarar a utilidade pública, para fịns de desapropriação ou instituição de servidão administrativa, de terrenos e benfeitorias, de modo a possibilitar a realização de obras e serviços de implantação de aproveitamento hidráulico ou de usina termelétrica cabendo ao produtor independente ou autoprodutor interessado em promover, amigável ou judicialmente, na forma da legislação especifica, a efetivação da medida e pagar as indenizações devidas. Ou seja, criou-se marcos legais para sobrepor alguns interesses a outros no acesso e uso da água.

Nena- "Eu acho que eles tão passando na frente. ultrapassando barreira que eles não podem, tão coagindo pessoas, obrigando, fazendo pressão sobre a pessoa, que tem muita gente que acha que é lei. Eu. tendo algum estudo, alguma coisa, então eu entendo, mas tem pessoas que estão sendo explorada mesmo, são pessoas da cidade, aqui, que às vezes tem algum comércio, então tem um monte que chega e assina com medo da desapropriação, "ah, vou ser desapropriado". Eles falam que vão fazer depósito. Eles tão pensando o quê? Que o BNDES vai financiar pra eles. Eu acho que é por aí que eles tão fazendo.

Acho que não é bem isso, porque, hoje no valor de mercado, que qualquer um que tem terra aqui na região nossa, eles vão plantar, a terra vai ser produtiva pra gerações, eles não tão vendo isso, tão pegando em terras reprodutivas em cana que vai produzir, quarenta anos de cana. Então os valores que eles estão 
oferecendo năo é o real do mercado. acho que eles tem que saber o valor do mercado ou até mais, porque ninguém está disposto a vender. Eu acho que tinha que ter uma coisa a mais pra eles proporcionar. Porque se o dono tiver disposto a vender. tá aberto à venda, tudo bem. Ali tem proprietário, por exemplo eu tenho rancho ali há quinze anos, tem gente que tem rancho ali que não é pra vender, tem gente que mora. tem uns dez moradores lá.

(...) Outra coisa, eles não podem fazer isso de proibir você de ter acesso à represa. é um bem público. e eles então tão agindo de má fé. Como é que você tem um rio e ninguém pode ir lá visitar o rio? É intocável, fica lá e ninguém pode? Vai proibir todo mundo? Pescar, passear, ir lá levar o filho pra fazer um passeio ecológico, você não pode fazer isso?" (sr. Nena, morador de SJB, líder dos rancheiros e proprietários de um dos ranchos do condomínio que será inundado)

João - (...) com essas novas legislações você não vai poder ter acesso indiscriminado ao outro, mesmo porque se a SEBAND for responsável por plano de manutenção dessa APP (área de presenvação permanente), o que que vai acontecer..., se eu sou responsável, não vai entrar qualquer um não, senão daqui a pouco tá fazendo piquenique, assando um churrasquinho lá no meio, pondo fogo na mata e perante o ministério público e a secretaria do meio ambiente eu sou responsável, então, isso vai ser cercado tudo, né! E vão ter até através de reunião pública vamos definir locais para o público, porque eu não posso impedir você de ter acesso à água. mas ele vai ser pré-estabelecido vai ser aqui que todo mundo vai entrar ou ali, mas vai ser pré- estabelecido, o resto não tem acesso, mas se você quiser andar de jet-ski etc., você vai ter um local para descer, porque é público. E tá todo mundo, o grande problema é que, por exemplo, se você fosse proprietária, o que legal não quero saber se o alqueire é pouco é óbvio que eu vou lutar pra que ele seja um mar, mas pô já pensou eu descendo minha lancha, meu jet-ski aqui. tô com um mar na minha porta, não é assim não, então, isso que acaba ocorrendo uma pequena interrogaçăo de êh... entendeu iss, mas como eu sou dono terreno e não posso ter acesso água? E se eu tiver gado? Meu amigo, teu gado não vai à água, é uma obrigação da SEBAND levar água até o teu gado, mas teu gado não vai na água não, mete bomba. puxa pra cima, põe bebedouro, agora eu vou plantar árvore e lambe tudo a árvore vem eu de novo. planto de 
novo, amanhã vem o gado lambe de novo, fico plantando a de eternc, 1..., não existe, então, isso acaba dando alguns choques sociais, mas eu entenclr) (me é primordial o caso da energia. (sr João Mattaraia, vice- prefeito de Sáo Joilquim da Barra e representante local de SEBAND)

Com isso, pode-se afirmar o predomínio de uma racionalidade: (:n que a natureza torna-se apenas objeto de exploração do capital, e:ncl, ela lançada à esfera da manipulação econômica e as culturis' loc;ais, majoritariamente, ficam à mercê dos investimentos capitalistas.

"a natureza é coisificada, desnaturalizada de sua complexidade (ir,ririrm;a é convertida em matéria prima de um processo econômico; e o: ru:cursos naturais tornam-se simples objetos para a exploração do capital $N_{\text {r }}$ : :17 da economia voltada à ecologia, a natureza deixa de ser um objeto dr, prrs,esso de trabalho para ser codificada em termos de capital"(Leff, 2003)

Ademais, as entrevistas realizadas com a população da Cidiarır: dr: São Joaquim da Barra revelaram a preponderância de um imarłınárıs de progresso construído e legitimado pela sociedade que ficou e Adrite na pesquisa de campo. Este imaginário construido em torno dis idi:la de progresso está calcado na crença de um possivel benefício a (r,pulação enquanto totalidade. Tal benefício recai na retórica da geração d : s:rripregos e absorção de mão-de-obra agregados ao advento tecnológicc, ": ırbano, juntamente coexistente ao anseio de se alcançar o poder sirriti,ili, o) do desenvolvimento e do progresso tecnológico com a equidade social

A respeito disso afirma Leff ( 2001):

"Diante do poder simbólico desta razão totalitária, ficamo: s:rn fala para afirmar nosso lugar no mundo, sem palavras para sigrifir,ir : dar sentido à nossa existência, sem um pensamento capaz de 'srr:ritar a construção de nosso futuro. (...) Impotentes diante das estratégi:', lintiais da 
globalização, de uma hiper-realidade inescapável que penetra nosso tecido vital, aniquilando o pensamento crítico e a ação criativa" (p.120)

Diante disto ficou inteligivel que a sociedade é imbuída de uma racionalidade econômica que fica claro no discurso popular:

Entrevistador - Vocês não tem nenhuma informação? Vocês assim não têm nenhuma opinião? O que vocês acham sobre a construção dessas usinas?

Marlene: "Otimo, é ótimo. É bom porque a cidade tá crescendo, vai ter muito trabalho aqui pra gente. É ótimo, vale a pena." (sra. Marlene, moradora de São Joaquim da Barra).

"Se trazer emprego pra cidade nossa era interessante, né? Porque é o que tá precisando. Vixe, é o que mais precisa. Porque também se não tivesse essas usinas aí nós tava perdido, né?

São úteis de mais é! Porque trás muito emprego pra cidade, a nossa sorte é essas usinas aí!" (sr. Marcos, morador de São Joaquim da Barra).

"Eu pra ser sincero pro cê, pra gente é bom por causa do serviço, vai gerar emprego. (amigo- com certeza, qualquer obra gera emprego, primeiro na construção civil, principalmente, né? E depois lá pra gerar a energia. Depois não, porque eles põem o computador lá, você sabe disso, né? E tira serviço de vinte. Mas pelo menos neste período, sei lá se são cinco anos, não sei quantos anos, né, vai dar serviço pra população)." (sr. Gusmão e amigo, moradores de São Joaquim da Barra).

"(...) eles simplesmente postaram a favor porque, vão ser por volta de 1.000 empregos diretos, um investimento na ordem de 150, poderia chegar até 200 milhões de reais, quer dizer, isso porque vocês são cidade de primeiro mundo, mas se vocês saíssem um pouco do pólo $A B C D$ viessem um pouco pra cá e pegasse um investimento desse, vocês vão ver que estariam rindo à toa, tá certo, 
muito legal pega uma situação dessa..." (sr. João Mattaraia, vice-prefeito de SJB e representante local da SEBAND).

"não..., construção civil é..., uma usina dessa com dois anos está pronta, acabou a mão de obra, é aí, depois, o funcionamento hoje a gente sabe que a tecnologia não é tanto funcionários assim, quer dizer, já não precisa mais." (sr. Valter Martins, vereador e presidente da Câmara dos Vereadores de São Joaquim da Barra).

São poucos aqueles cidadãos que tem o conhecimento que, diante do funcionamento de usinas hidrelétricas, é demandado mão de obra apenas no processo de construção da mesma, que se limita a poucos anos, somente até a finalização da obra. Depois, sua operação acaba sendo quase que totalmente automatizada, restando pouquíssimos empregos para a população ativa.

A distância etária revelou, ainda, as diferenças culturais e as formas de conhecimento disseminadas a cada geração. Isto ficou claro na paróquia central da cidade. Lá, dentre todos os entrevistados, um único demonstrou preocupação perante os danos ambientais que uma usina hidrelétrica pode trazer à fauna e à flora de uma cidade, sendo ele um jovem seminarista, educado em uma realidade contemporânea a qual a racionalidade ambiental é fomentada.

"As construções das usinas por um lado é bom, porque traz benefício pra cidade, enquanto economia, mão- de -obra, emprego pras pessoas mas, por outro lado, trás os malefícios que a gente sabe sobre o ecossistema, destrói a vegetação da região, se bem que na região, nós não temos quase nada da vegetação, é mais cana de açúcar". (Jovem seminarista da Igreja da praça central de SJB). 
Da mesma forma, para o líder dos rancheiros, a preocupação ambiental se mostrou bastante presente em várias de suas falas, como por exemplo:

"Lá na usina, eles fazem um negócio que chama manobra, de segurar água pra acumular energia. Ás vezes eles abrem o ladrão, chama ladrão. que eu já vi funcionado, abre entra água, e também quando eles baixam, os peixe tudo fica, eu já vi gente pegar assim 500 quilos de peixe com a mão. É uma judiação. O que eles fazem, eles tinha que montar a usina e por um posto de guarda florestal lá dentro, acho que era o certo. E que não tem em outras usinas, eles só ficam falando que vão fazer isso, que vão fazer aquilo...eles tinham que esclarecer tudo isso, mostrar pra população, apresentar em jornal, vai pro jornal, mostra o papel, tantos lugares, tá aqui ó, "esta área compramos", "vamos reflorestar tal área", "vamos soltar tantos peixes", e o grande problema é que eles não tem nada disso. Pra gente ele não perguntou nada. Que tipo de peixe, animal, ele tá só preocupado com a construção. Só quer levantar, construir, ganhar o dinheiro dele e pronto.

Entrevistador - E também tem que, é muito importante, considerar o momento de lazer, é um momento muito importante, é toda uma cultura, uma cultura caipira, envolve relações sociais.

É, por exemplo, eu pesco desde os seis anos com meu pai...já faz 29 anos que eu vou pescar, sou apaixonado por pesca esportiva, meu pai com 74 anos pesca até hoje aí no rio. A pesca esportiva é liberada, mas mesmo dentro da barragem tem um limite, é mais também por perigo né, de estar lá dentro da usina, então tem uma preocupação. Mas a pesca esportiva hoje é uma pesca liberal, de vara hoje, só não pode de rede, tarrafa pesca predadora vamos dizer." (sr. Nena, líder dos rancheiros e morador da cidade de SJB).

"Primeiro que aqui ninguém vive de pesca, embora o rio seja excessivamente piscoso, ninguém vive de pesca aqui, mas, tá interferindo no direito de ir e vir, tá, então veja bem, você pode do mesmo jeito que as empresas, esse é o preço do 
progresso, eu pergunto a você os pescadores, que gostam de praticar a pesca, ele sai daqui e vão pra represa de Miguelópoles, que deve de estar daqui uns $70 \mathrm{Km}$, a represa a produtividade é muito maior, tucunaré da mais em represa. desova em rio grande. ele prefere a água represada. então, a pesca em si eu num vejo que poderia ser afetado em hipótese alguma. os estudos complementam a existência de escada de peixe, vai ter que construir. Então não enxergo isso." (João Mattaraia, vice-prefeito de SJB e líder local da SEBAND).

Essa manipulação econômica legitima uma visão desenvolvimentista em que o homem não faz parte desse todo, a natureza. Ignora, assim, todas as identidades culturais e a singularidade do local que compõem o território e demonstra a ineficiente sustentabilidade ecológica, uma vez que, a modernidade concebeu o progresso baseado no esquecimento, ignorando que o território é imbuido de todas estas dimensões elencadas acima e formador de uma memória social.

"A memória cumpre um papel fundamental na proposta de reconciliação entre a natureza e a sociedade. Se a natureza deve compreender-se não apenas como algo externo, mas também como algo interno ao homem, toda reificação será então um esquecimento." (Leis, 1997).

"É um espaço onde surgem tempos diferenciados, onde se articulam identidades culturais e potencialidades ecológicas"(Leff, 2003).

Ainda assim, para os três aproveitamentos, Anhanguera, Palmeiras e Retiro, em 1 de Junho de 1994, a Secretaria de Estado do Meio Ambiente do Estado de Säo Paulo (SMA -SP) concedeu a Licença prévia (LP), com base no Parecer Técnico SMA n. 7.502/90 e na Deliberação CONAMA 21/91, que aprovou os referidos aproveitamentos, apresentando, um 
conjunto de exigências a serem cumpridas quando da solicitação da Licença de Instalação (Li) como:

- projeto executivo de reflorestamento ciliar;

- projeto de implantação de viveiro;

- levantamento detalhado da fauna;

- programa de reassentamento da fauna;

- programa de resgate da fauna nas fases de limpeza e enchimento dos reservatórios;

- programa de desinfecção de currais e tamponamento de poços.

Entretanto, sabe-se que a Licença Prévia Ambiental (LP) deve ser concedida na fase preliminar do planejamento da atividade contendo requisitos básicos a serem atendidos e observados os planos municipais, estaduais ou federais de uso do solo. Sua emissão deve ocorrer após a aprovação do Estudo de Impacto Ambiental e seu Relatório de Impacto Ambiental e configura-se indispensável para solicitação de financiamentos e obtenção de incentivos fiscais. A finalidade da LP é estabelecer condições tais que o empreendedor possa prosseguir com a elaboração de seu projeto. Corresponde a um comprometimento por parte do empreendedor de que suas atividades serão realizadas observando os pré-requisitos estabelecidos pelo órgão de meio ambiente (Karla Pohlmann e Marisa Rotenberg, da Habilita in (http://muw.canalenergia.com.br) Acesso: 16/03/2004).

Para os referidos casos, no entanto, observamos que algumas etapas foram suprimidas do Estudo de Impacto Ambiental e, mesmo assim, a licença 
prévia foi obtida. Das análises suprimidas tem-se, principalmente, aquelas que se atém ao meio antrópico e aos estudos sociais como: aspectos relativos à qualidade de vida da população atingida, à composição, estrutura e à expectativa diante da necessidade de uma mudança compulsória, das perdas de valores estéticos, de valores e referências culturais, de monumentos ou valores históricos, de terra para agricultura, sem contar a degradação da qualidade da água e do aumento de $\mathrm{CO}_{2}$ no fundo dos resevatórios estratificados, quando da formação desses lagos artificiais.

Valter - (...) porque aquilo ali é uma usina nesse sentido vai danificar e é irreparável, ah..., fauna, quer dizer vai ser totalmente irreparável isso, né? Por mais que tenham tido recuperar ou criar um ambiente, mas não é igual o ambiente da natureza.

Agora essas indenizações, é uma coisa que a gente assim não tem conhecimento de como vai ser o acerto disso, né? Eu acredito uns vão protestar, outras pessoas não vão aceitar, porque eu acho o seguinte. não é só o fator da indenização, existe também o aspecto sentimental, né? A pessoa que foi lá construiu, criou um habitar, um ambiente, né? O seu espaço, né?

(...) não, não paga, veja bem, por mais que a pessoa... se chegar falar um negócio nós vamos construir uma idéia ou até melhor. vamos dizer assim, mas não é a mesma coisa que o sentimento daquela pessoa, eu vim aqui, eu levantei tijolo, eu construí eu fui plantando ánores frutiferas, e tudo quer dizer, nada disso. (sr. Valter Martins, vereador e presidente da Câmara dos Vereadores de São Joaquim da Barra)

"Tem fazendeiros que vai alagar muitos alqueires, tudo em cana, imagina o prejuízo pra pessoa. Tem gente que tem a fazenda faz mais de cem anos. cento e cinqüenta anos, que era do avô, tataravô, vem passando de geração em geração" 
- (sr. Nena, morador de SJB, líder dos rancheiros e proprietários de um dos ranchos do condomínio que será inundado)

Assim, tal estudo não deveria ser analisado só em decorrência da ocupação de determinado espaço pelo empreendimento (binômio tipologia e localização), mas também a sua consequente indisponibilidade para qualquer outra atividade; bem como dos impactos decorrentes da obra propriamente dita, das áreas de apoio à mesma e dos impactos em virtude da operação da usina em quantidade suficiente para que se pudesse embasar um planejamento ambiental de qualidade e não apenas uma maquiagem para os órgãos responsáveis pelo licenciamento.

Dessa forma, percebemos que não é suficiente promover a eficiência energética sem que haja desenvolvimento e desenvolvimento inclui comunicação e discussão ampla e democrática dos projetos. O crescimento no consumo de energia é inevitável, devido, às necessidades de se instalar uma infra-estrutura industrial, meios de transporte e crescimento urbano. Porém, não há desenvolvimento que ocorra de forma sustentável se não houver a participação da sociedade na tomada de decisão, definindo as necessidades e os problemas, os usos preponderantes e os requeridos.

O slogan "pensar globalmente e agir localmente", promovido tão tenazmente pelo discurso do desenvolvimento sustentável, induz ao desafio da sustentabilidade em construir uma racionalidade que se fundamente em bases ecológicas e em identidades culturais locais, onde os atores sociais possam exercem seu poder para controlar a degradação ambiental bem como, para mobilizar potenciais ambientais em projetos autogerenciáveis 
criados a fim de satisfazer necessidades, aspirações e desejos dos povos (Leff, 2003).

Isso nos leva a refletir que, na era da racionalidade econômica globalizada, independentemente da escala, a gananciosa disputa por novos mercados consumidores de energia, face as novas diretrizes do setor elétrico nacional e da rede de proteção e de incentivos fiscais com os quais - capital privado pode contar, está muito longe do ideário de sustentabilidade almejados nas políticas ambientais.

Nesses casos, a temática ambiental passa a ser apreendida por uma diversidade de agentes sociais, cada qual movido por demandas e interesses específicos, cada qual resignificando-a a seu modo. A complexidade ecológica acaba sendo convertida em fonte de matéria-prima de um processo econômico; e os recursos naturais tornam-se simples objeto para a exploração do capital, sem qualquer compromisso com a manutenção da integridade ecológica e do bem-estar social.

Não é novidade que a construção de UHEs causam impacto sócioambiental e, tratando-se de PCHs, mesmo com reservatórios de dimensões menores, em casos de relocação de famílias por inundação, o impacto para cada familia indivualmente é essencialmente o mesmo, no que concerne à lógica que move o processo. Por isso, a implantação dessas usinas deveriam ser tratadas com maior responsabilidade social do que, atualmente, demonstram ter.

João - "(...) se não for assim não faz, estamos considerado $\mathrm{PCH}$ como se fosse uma Itaipu, ou seja, vai inundar São Joaquim inteiro Guará inteiro... 
Entrevistador - Não, mesmo porque o reservatório de $\mathrm{PCHs}$ tem que ter $3 \mathrm{~km}^{2}$.

João - Menor que três, menor ou igual a três. Então, veja bem, para reservatórios pequenos onde a área de inundação é muito pequena, ele funciona mais como uma lingüiça, do que como um Furnas aqui próximo, que corre a 35 cidades, ela não vai abrir ela por exemplo, no eixo da barragem mais ou menos, não que isso seja os únicos, mas se você pegar na barragem, a tendência da barragem é fazer uma espécie de um saco, aí ele vai afunilando e entrando quando ele tá quase se aproximando da área de remanso ele é praticamente ele caixa do rio existente, então isso não afeta absolutamente em nada de família, mas foi levantado, cadastrado...

Entrevistador - Não, porque assim, não é uma Itaipu, uma Balbina, né? Mas o impacto para cada família é grande, por exemplo pode ser inundada 10 casas, 10 famílias mas para aquelas 10 o impacto é grande...

João - É ate acho, eu queria saber a respeito disso? O que você julga de impacto, vamos lá, o que poderia te nessas áreas que poderia comprometer, vamos cria um... hipotéticamente um morador lixeiro, então, ele a mulher e três filhos ah... primeiro pra ele ter um impacto a casa dele deveria estar na área de inundação, não existe, se eu não tô enganado, a área de inundação a não ser ranchos clandestinos esse, enfia quatro bambu, não existe..., primeiro é rancho, não é que mora gente lá, é você um pescador, construir levantou quatro paredes, primeiro você ta no meio de uma PP (APP-ÁREA DE PRESERVAÇÃO PERMANENTE), de maneira clandestina e você não reside lá, você tem aquilo pra lazer e foi construido sem a menor autorização possivel, então fora esses ranchos, eu não conheço nessas três usinas alguma família que teria ali a casa inundada, mas vamos supor que tivesse, a SEBAND está se prontificando a pegar essa situação sai fora de toda benfeitoria seja ela inundada ou que se encontra dentro da área de reflorestamento, ou indenizar o valor dela ou reconstruí-la fora do cilício do negócio, então, pergunto, qual seria o prejuízo que você teria tomando, se você fosse a moradora lá..." (sr. João Mattaraia, vice-prefeito de SJB e representante local da SEBAND). 
"Eu acho que ele como morador, como uma pessoa pública, que ele é ,como viceprefeito atualmente e candidato a prefeito ele devia pelo menos ser mais sensato e agir de boa fé com a população. É isso aí que eu penso dele e da empresa. Eu como presidente do clube, eu tive uma oferta e vou falar, foi justa pra mim, vendi meu rancho, dei uma proposta de venda pra eles, mas muita gente não foi de acordo com que o rancho vale...

Falta informação, falta estudos dele sobre a fauna e a flora, será que eles tão preocupado com isso? Cadê o lugar que tem que fazer as reservas? Lugar que eles vão dar pra nós? Se tivesse tudo direito, todo mundo ia estar de acordo. Eu acho assim, tudo que tem que fazer tem que ter um projeto, ele não pode agir sem ter mostrado o projeto de nada. Tudo isso tem que ser provado e eles não podem provar o que eles estão falando. Primeira coisa eu acho que ele deveria deixar claro as coisas pra todo, não só nós do condomínio mas pra toda cidade, morador da cidade..." (sr. Nena, morador de SJB e líder dos rancheiros).

Nessa configuração supra, o estudo de caso deixou claro esta sobreposição de valores, em que a produção de energia para o desenvolvimento do país se sobrepões à multiplicidade de recursos naturais e humanos, relocando famílias inteiras de ribeirinhos sem a devida preocupação com suas condições futuras, a não ser com uma certa quantidade de dinheiro a ser pago à título de indenização, seja amigável ou judicialmente.

Ademais, a análise dos problemas ambientais e suas imbricações na ordem democrática e na forma de apropriação do território e seus recursos é orientada segundo interesses setoriais, no caso, energéticos. Onde restam poucos fóruns para que os cidadãos comuns possam reclamar e reinvidicar seus direitos já que as audiências públicas não atingem a 
divulgação necessária e, muitas vezes, quando anunciadas já são fato consumado.

Quanto aos recursos hídricos, o que se observou foi a preponderância do uso para fins hidrelétricos, sem qualquer compromisso com o planejamento regional, estadual e sim com os propósitos econômicos e desenvolvimentistas da concessionária responsável, renegando não apenas os direitos sociais de outrém, mas o direito à vida das demais espécies que dependem da água, o que amplia a suscetibilidade dos ecossistemas aquáticos naturais (ou terrestres que da integridade deste dependam).

Por tudo isso, o setor elétrico, ao nosso ver, tem passado ao largo da observância dos direitos de Cidadania. E, alguns cidadãos, não tratados como tal, não são apenas meros consumidores de energia, são, ainda, residentes de área diretamente afetadas por obras do referido setor. Essa dupla relação carece de estudos de campo mais aprofundados nos quais precisam ser contempladas as contradições entre a garantia de certos modos de vida e a acumulação de capital. 
Face ao exposto ao longo deste trabalho, as principais conclusões a que chegou-se são as que seguem:

日 $O$ segmento da hidroenergia não perdeu sua importância no processo de ampliação das possibilidades econômicas e sociais que o Estado antevia para a nação;

- O lugar estratégico da hidroenergia foi aberto ao domínio dos interesses privados, inclusive transnacionais, em uma circunstância em que o setor público alegou insuficiência crônica de recursos;

Em termos operativos, de negócios que livra os empreendedores de riscos e embaraços não permitiu ao Estado o fortalecimento ou reconstituição de sua capacidade fiscal;

目 $\mathrm{O}$ Estado não retirou-se de quaisquer funções de uso de recursos públicos no setor (o qual alegava não ter), apenas deslocou-se para a função de banqueiro solícito à acumulação privada, concedendo, via BNDES, apoio creditícios que acabam por minar mais intensamente as contas públicas que jurou sanar.

E Embora o ambientalismo brasileiro tenha conquistado forte institucionalização, as políticas públicas setoriais acabam por fazer com que o discurso - legislação bastante "ambientalizado" não logrem o êxito pretendido, principalmente, quando o assunto for produção de energia para o desenvolvimento do país. 
目 Por fim, o estudo de caso, num contexto de privatização e expansão do setor elétrico, reiterou um padrão de desenvolvimento baseado na exploração do meio ambiente e pouca efetividade decisória dos agentes sociais afetados.

Esses aspectos remetem para a ampliação da insustentabilidade econômica do pais, entendendo por isso a incapacidade nacional em autogerir contas, produção, formação de preços e cuidados com o ambiente natural. Sendo, este último, centralmente focado na água, subordina necessidades vitais, humanas ou não, à acumulação privada, o que coloca o nível de vulnerabilidade da existência de um povo num patamar não apenas elevado mas, também, sem precedentes.

É preciso reconhecer que a escolha da forma de implementação de políticas públicas depende de contextos específicos de cada período e de cada país, e que não existe um "modelo ótimo de implementação", aplicável a qualquer caso.

Também convém entender que qualquer modelo de regulação do setor elétrico só será viável e atingirá seus objetivos num contexto de regras claras definidas em esfera nacional. De nada adianta atrativos institucionais e promessa de uma rede de proteção estatal com a qual o capital privado poderá contar se, de um lado há o problema estrutural da economia brasileira e, de outro, o da vulnerabilidade política a que a sociedade está exposta

Admitir que, embora a legislação ambiental no Brasil esteja entre as mais avançadas, a realidade brasileira mostra que existem sérias 
dificuldades para a implementação da atual politica de meio ambiente, inclusive referindo-se à possíveis manobras na legislação ambiental em favor de interesses setoriais. Contudo, se os aspectos ambientais supra forem devidamente equacionados, a implantação de qualquer atividade ou empreendimento poderá se refletir em uma garantia ao investidor de que ele não terá surpresas futuras. que venham onerar seu orçamento.

Ainda, compreender que, obedecendo a Lei Federal n. ${ }^{\circ} 9.433$ de 1997, ao buscar sempre o uso múltiplo das águas, por meio de uma gestão integrada dos recursos hídricos com os demais setores usuários, o investidor poderá, inclusive, visar a possibilidade de diminuir a parcela de investimento aplicada no empreendimento, por rateio do custo total, e maximizar os benefícios nas áreas ambiental, sócio-econômica, energética e outras, na medida em que se pode implantar programas de ações contínuas que estimulem a proteção das águas contra ações que possam comprometer seu uso atual e futuro;

Por fim, reconhecer que não é novidade que a construção de UHEs causam impactos sócio-ambientais e, por isso mesmo, a sua implantação deveria ser tratada com maior responsabilidade social do que, atualmente, demonstram ter. A viabilidade econômica do empreendimento deveria ser apenas um dos itens de análise igualmente importante à Avaliação de Impacto Ambiental e à participação da sociedade local no processo de tomada de decisão e na busca de soluções já que

"o território é o lugar onde a sustentabilidade se fundamenta em bases ecológicas e em identidades culturais. É o espaço social onde os atores sociais exercem seu poder para controlar a degradação ambiental e para mobilizar potenciais ambientais em projetos autogerenciáveis criados a fim 
de satisfazer necessidades, aspirações e desejos dos povos, que a globalização econômica não consegue cumprir" (Leff, 2003).

\section{Sugestões para estudos futuros:}

Em vista da finalização deste estudo (em Setembro de 2004) em meio ao processo de reestruturação do setor, novos percalços são vislumbrados e é mister analisá-los.

Assim, em continuidade às dimensões sócio-políticas e ambientais a este estudo, sugere-se que haja um esforço futuro de investigação que contemple os seguintes aspectos:

- a comparação entre as vantagens e desvantagens, sob diversas nuances, do modelo atual do setor elétrico nacional e o modelo antigo estatal;

- a análise dos avanços e acertos do modelo regulatório do governo Lula (lançado em 2004) com o proposto nos Governos FHC I e II (1994 à 2002).

- a avaliação da influência das agências financeiras multilaterais na implementação de políticas públicas setoriais. 


\section{BIBLIOGRAFIA}

- ABRACE. Associação Brasileira de Grandes Consumidores Industriais de Energia. Clipping Abrace. BNDES deve destinar $30 \%$ da verba de energia para PCHs. (http://www.abrace.org.br). Acesso: 01/04/2004.

- ANDRADE, M.C. de. Território, globalização e fragmentos. São Paulo: Hucitec, 1994.

- ANDREOLI E FERNANDES. Principais componentes do processo de Avaliação de Impacto Ambiental. In: IAIA - International Association for Impact Assessment - seção brasileira, v.1, n.2, 1996.

- BARROS, F.L. de Ambientalismo, globalização e novos atores sociais. Sociedade e Estado, v.XI, n.1, jan./jun., 1996.

- BERGER, J. The economy and the environment. In: SMELSER, N.J.; SWEDBERG, R. (editors). The handbook of economic sociology. Princeton University Press. Princeton, N.J.; Russell Sage Foundation, New York, 1994.

- BERMANN, C. Indústrias Eletrointensivas e Autoprodução: propostas para uma política energética de resgate do interesse público. In: ILUMINA, (http://www.ilumina.org.br). Acesso: 01/04/2003. 
- BICUDO, H.; NETO, P.M.; ALMEIDA, G.A. Direitos Humanos e Sociedade Civil. Tendências e Debates. Folha de São Paulo, 30/06/2004.

- BOBLIO, N.; MATTEUCCI, N.; PASQUINO, G. Dicionário de política. 2.ed. Brasilia: Hamburg, 1986.

- BRESSER- PEREIRA, L.C. Chutando a Escada. Tendências e Debates. Folha de São Paulo, 04/07/2004.

- BULCÃO, J.A.S. Principais impactos sobre a saúde da população afetada por projetos hidrelétricos. In: Soluções para a energia no Brasil. IX CONGRESSO BRASILEIRO DE ENERGIA, IV SEMINÁRIO LATINO-AMERICANO DE ENERGIA. 2002. Anais. Vol.1. Rio de Janeiro, Maio, p.78-86.

- CANO, W. Reflexões para uma Política de Resgate do Atraso Social e Produtivo do Brasil na Década de 1990. In: Reflexões sobre o Brasil e a nova (des)ordem internacional. São Paulo/Campinas: Fapesp/Editora da Unicamp 13-48, 1994.

- CAVALCANTI, C. Sustentabilidade da Economia: paradigmas alternativos de realização econômica. In: CAVALCANTI, C. (org.). Desenvolvimento e Natureza: estudos para uma sociedade sustentável. São Paulo, Cortez; Recife - PE: Fundação Joaquim Nabuco. Parte I, Cap.9, p.153-174, 1995. 
- CENTRO DA MEMÓRIA DA ELETRICIDADE NO BRASIL. Guia dos fundos documentais do setor de energia elétrica brasileiro. Rio de Janeiro, 1989. 42.5p.

- CERNEA, MM. Propostas sócio-econômicas e culturais para o reassentamento populacional involuntário. In: HASHIMOTO, M. (ed.) Diretrizes para o gerenciamento de lagos. Aspectos sócio-econômicos do gerenciamento de lagos/reservatórios. Volume 2. Comitê Internacional do Meio Ambientє (ILEC). Programa das Nações Unidas para o Meio Ambiente (UNEP), 1995

- CETESB - Companhia de Tecnologia de Saneamento Ambiental. Compêndio de Legislação Federal, 1994.

- COMPANHI F PAULISTA DE FORÇA E LUZ (CPFL). Relatório Final do Projeto Básico. Aproveitamentos: Anhanguera (8574/GE-10-RL-2001-1), Palmeiras (8.574/GE-10-RL-1001-1) e Retiro (8574/GE-10-RL-3001-1). ENGEVIX Enģ

- COTRIM, $J=K$.; SATO, T. O investidor privado e sua ótica para dimensionamento de usinas hidrelétricas. In: A água em revista Ensaios e disšrações. n. ${ }^{\circ}$ 04, Fev.; p.12-14, 1995. 
- DEPARTAMENTO NACIONAL DE ENERGIA ELÉTRICA. Avaliação da oportunidade e das condições para lançamento de um novo programa de implantação e de recuperação de pequenas centrais hidrelétricas PCH. Secretaria de Energia, Ministério de Minas e Energia. (Relatório de grupo de trabalho. Portaria n. 776/94), 1995.

- EFICIÊNCIA ENERGÉTICA. Medo do apagão. In: Metalurgia \& Materiais. ABM. vol.59 - n.o 535 - Julho de 2003 pág. 376 e 377.

- ELETROBRÁS - Centrais Elétricas Brasileiras S.A. Plano diretor de meio ambiente do setor elétrico 1991/1993. Rio de Janeiro: Eletrobrás, 1990.

- ELETROBRÁS - Centrais Elétricas Brasileiras S.A. Programa de desenvolvimento e comercialização de energia de pequenas centrais hidrelétricas (PCH-COM). Disponivel em: <http://www.eletrobras.gov.br>. Acesso em: 02/07/2001.

- ElETROBRÁS. Centrais Elétricas Brasileiras S. A. (http://mww.eletrobras.gov.br)

- ELLIOTT, J.A. An introduction to sustainable development. Nova York: Routledge, 1994. 
- ENGE-RIO. Aproveitamento Hidrelétrico do Rio Sapucaí - SP. UHE's Retiro, Anhanguera e Palmeiras. Relatório Final do Projeto Básico. Vol.1, 1989.

- FERREIRA, C.K.L. Privatização do Setor Elétrico no Brasil. In: PINHEIRO, A.C. e FOKASAKO, K. (orgs.). A privatizaçao no Brasil: O caso dos serviços de utilidade pública. Rio de Janeiro: BNDES/FINANAME, BNDES, 2000.

- FERREIRA, L. da C. A busca de alternativas de sustentabilidade no poder local. In: FERREIRA, L.da C.; VIOLA, E. (Orgs.) Incertezas de sustentabilidade na globalização. Campinas: Universidade Estadual de Campinas (UNICAMP), 1996.

- FIORI, J.L. Palestra proferida no Centro Cultural Banco do Brasil sobre o Consenso de Washington, 04/09/1996.

- FURNIVAL, C.A; COSTA, L. R. Informação ambiental e práticas culturais de comunicação para o desenvolvimento sustentável. In: MARTINS, R.C.; VALENCIO, N.F.L.S. (orgs). Uso e gestão dos recursos hídricos no Brasil: aspectos teóricos e político-institucionais. Volume II. São Carlos: Rima.53-70, 2003. 
- FURTADO, C. Teoria e política do desenvolvimento econômico. Ed. Nacional, São Paulo, 1977.

- GASPARI, E. O apagado pagará pelo apagão. Folha de São Paulo, 24/03/2002.

- GOLDEMBERG, J. Energia, meio ambiente e desenvolvimento. São Paulo: Editora da Universidade de São Paulo, 1998.

- GOMES, F.A.M.. A eletrificação no Brasil. Eletropaulo, 1986.

- GUIVANT, J.S.; JACOBI, P. Da Hidro-Técnica à Hidro-Política: Novos rumos para a regulação e gestão de riscos ambientais no Brasil. Cadernos de Pesquisa Interdisciplinar em Ciências Humanas.n.43. Junho, 2003.

- HONTY, G. Impactos Ambientales del Sector Energético en el Mercorsur 2001. Disponivel em: (http://www.icem.org.br/impactos\%ambientales.doc).

- IANNI, O. Teorias da globalização. 2 ed. Rio de Janeiro: Civilização Brasileira, 1995. 
- INFOENERGIA. Pequena hidrelétrica em Rondônia terá direito a recursos da CCC. (http://mww.infoenergia.com.br/Noticias). Acesso: 01/04/2004.

- JACOBI, P.R.; MONTEIRO, F.; NOVAES, R.; ROMAGNOLI, R.; EDUARTE, M.; CASTELLANO, M., Fabiana (USP): Capital Social nas bacias hidrográficas- desafios metodológicos para sua mensuração. In: Soluções para a energia no Brasil. III ENCONTRO DA ANPPAS (ASSOCIAÇÃO NACIONAL DE PÓS-GRADUAÇÃO E PESQUISA EM AMBIENTE E SOCIEDADE.). 2004. Indaiatuba, SP, 26 a 29 de Maio.

- LEFF, E. A geopolítica da biodiversidade e o desenvolvimento sustentável: economização do mundo, racionalidade ambiental e reapropriação social da natureza. In: MARTINS, R.C.; VALENCIO, N.F.L.S. (orgs). Uso e gestão dos recursos hidricos no Brasil: aspectos teóricos e político-institucionais. Volume II. São Carlos: Rima.1-19, 2003.

- LEFF, E. Ecologia y capital. In: LEFF, E. (coord.). Los problemas del conocimiento y la perspectiva ambiental del desarollo, Siglo XXI, México. Universidad Autónoma de México, 1986. 
- LEIS, H. R. Para uma Genealogia do Ambientalismo. In: Cadernos de Pesquisa, nº Março, 1997.

- LEME, A. A. A reestruturação do setor elétrico brasileiro: privatização e crise em perspectiva. In: FELICIDADE, N.; MARTINS, R.C.; LEME, A.A. (orgs). Uso e gestão dos recursos hídricos no Brasil. São Carlos: Rima. 105-133, 2001.

- LEME, A. A. A reestruturação do setor elétrico brasileiro: uma abordagem sociológica acerca da privatização. Dissertação (Mestrado) apresentada ao PPGCSo - UFSCar, São Carlos, 2003.

- LOURENCÃO, L. dos S.; LIMA, T.P.F. da S. Estudo de planejamento energético de lugares isolados. Artigo fornecido na disciplina Aproveitamentos Hidrelétricos, da Engenharia Elétrica da Escola de Engenharia de São Carlos - USP. Jun/2000. (1999).

- MACHADO, P.A.L. Direito ambiental brasileiro. 3 ed. Revista dos Tribunais LTDA.

- MAIA. Manual de Avaliação de Impactos Ambientais, 2.ed., 1993. 
- MAIMAN, D. Eco - estratégia nas empresas brasileiras: realidade ou discurso. In: Revista de Administração de Empresas /EAESP/FGV, São Paulo, Brasil, v.34, n.4, Jul/Ago, 1994. p.120-130.

- MARIOTONI, C.A.; BADANHAN, L.F. Técnica de gestão ambiental aplicada ao planejamento energético. Universidade Estadual de Campinas/Companhia Paulista de Força e Luz. Campinas: ISBN 859042311-5, 2001.

- MARIOTONI, C.A.; MAUAD, F.F. Vantagens da viabilização de pequenas centrais hidrelétricas relativamente ao planejamento energético estratégico no Estado de São Paulo - Brasil. Lisboa: IV Simpósio de Hidráulica e Recursos Hidricos dos Países de Língua Portuguesa, 1999.

- MARTÍNEZ-ALIER, J.; SCHLUPMANN, K. La ecología y la economía. México: Fondo de Cultura Económica, 1993.

- MARTINS, R.; VALENCIO, N. A concretude da moderna crise sócioambiental. In: Uso e gestão dos recursos hídricos no Brasil: desafios teóricos e político-institucionais. São Carlos: Ed. RiMa, 21-34, 2004. 
- MILARÉ, E. Estudo prévio de impacto ambiental no Brasil. In: PLANTENBERG, M.; AB'SABER, A.N. (1994). Previsão de Impactos. EDUSP, p.51-83, 1994.

- MORAES, A.C.; COSTA, W.M. A valorização do espaço. 2 ed. São Paulo: Hucitec, 1984.

- MORAES, A.C.R. Meio ambiente e ciências humanas. São Paulo: Hucitec, 1994.

- MORAES, A.C.R.; COSTA, W.M. Geografia crítica. A valorização do espaço. Hucitec. 2. ${ }^{\text {a }}$ ed., 1987.

- OLIVEIRA JR., A.V. de C.; GUERRA, S.M. Distribuição de energia e direito ambiental: uma análise da situação brasileira. In: Soluções para a energia no Brasil. IX CONGRESSO BRASILEIRO DE ENERGIA, IV SEMINÁRIO Latino-Americano de energia. 2002. Anais. Vol.1. Rio de Janeiro, Maio, p. 132-143.

- NORMANDE, E.B. Avaliação de Impacto Ambiental de Barragens. Uma breve revisão. CRHEAVEESC - USP. São Carlos, SP, 1994. 
- OLIVEIRA, Francisco de. Democratização e Republicanização do Estado. São Paulo: Cenedic-FFLCH-USP, s/d (mimeo).

- PACCA, S.A. A integração das pequenas centrais hidrelétricas ao meio ambiente e os aspectos legais relacionados. São Paulo. Dissertação (Mestrado) - Programa Interunidades de Pós-Graduação em Energia, Universidade de São Paulo, 1996.

- PIRES, J.C.L. Desafios da Reestruturação do Setor Elétrico Brasileiro. In: BNDES (http://unw.bndes.gov.br) Textos para discussão, 2000.

- PIRES, J.C.L. O Processo de Reforma do Setor Elétrico Brasileiro. Revista do BNDES, Rio de Janeiro. v.6, n.12, p.137-168, Dez, 1999.

- PlantenBerg, M.; AB'SABER, A.N. Previsão de Impactos. EDUSP, 1994.

- PORTO, L.C. Geração Alternativa. In: 4.o Encontro de Negócios de Energia. Notícias. FIESP/CIESP. Ano 5 n.o 110 - Setembro de 2003, pág. 28. 
- REVISTA NOTICIAS FIESP/CIESP. A energia que o Brasil precisa. Em discussão, o novo modelo regulatório para o setor. Ano 5 n. ${ }^{110}-$ Setembro, 2003.

- REZENDE, F.; PAULA, T.B. (coord.). Infra-estrutura: perspectiva de reorganização. Setor Elétrico. Brasília: IPEA, 1997.

- ROSA, L. P.; TOLMASQUIM, M. T. E PIRES, J. C.L. A reforma do setor elétrico no Brasil e no mundo: uma visão crítica. Rio de Janeiro: Relume Dumará: Coppe, UFRJ, 1998.

- ROSA, L.P. et al. (coord.). Impactos de grandes projetos hidroelétricos e nucleares - Aspectos econômicos e tecnológicos, sociais e ambientais. AIE/COPPE e Editora Marco Zero em co-edição com o CNPq, 1998.

- ROUSSEF, D. Investimento evitará novo apagão. In: Folha de São Paulo. DINHEIRO, 15/03/2004.

- ROUSSEF, D. 4. Encontro de Negócios de Energia. In: REVISTA NOTÍCIAS FIESPICIESP. A energia que o Brasil precisa. Em discussão, o novo modelo regulatório para o setor. Ano 5 n. ${ }^{\circ} 110$ - Setembro, 2003. 
- SACHS, I. Estratégias de transição para o século XXI. In: BURZTYN, M. (org.). Para pensar o desenvolvimento sustentável. São Paulo: Brasiliense, 1994.

- SANTOS, M. Metamorfoses do espaço habitado. 5 ed. São Paulo: Hucitec, 1997.

- SANTOS, M. O espaço do cidadão. São Paulo: Nobel, 1992.

- SANTOS, M. Racionamento, O Risco de 2007. In: 4.o Encontro de Negócios de Energia. Notícias. FIESP/CIESP. Ano 5 n.o 110 - Setembro de 2003, pág. 28.

- SANTOS, M. Técnica espaço tempo. Globalização e meio técnicocientífico informacional. $4 .^{\text {a }}$ ed. São Paulo: Hucitec, 1998.

- SAUER, I. Energia elétrica no Brasil contemporâneo: a reestruturação do setor, questões e alternativas. In. Política energética e crise de desenvolvimento. São Paulo: Paz e Terra, 2002.

- SOUZA, M. P. de Instrumentos de gestão ambiental: Fundamentos e prática. São Carlos: Riani Costa, 2000. 
- SOUZA, P.A.P.; FELICIDADE, N.; MAUAD, F.F. A crise energética brasileira: Algumas dimensões do contexto político institucional e das alternativas em curso. In: PROGRAMA DE PÓS-GRADUAÇÃO EM CIENNCIAS DA ENGENHARIA AMBIENTAL. (orgs.). Recursos Hidroenergétcios: usos, impactos e planejamento integrado. São Carlos: Rima, 2002.

- SOUZA, P.A.P.; SOUZA, M.P. Estudo da viabilidade ambiental na implantação de pequenas centrais hidrelétricas no alto da bacia do rio Jacaré-Guaçu. Fator Gis On line, Paraná, Nov./1999. Disponível em: <http:wnw.fatorgis.com.br/artigos/meioamb/artigos_meioambiente.shtml>. Acesso em: 07/2001.

- TEIXEIRA, B.A.N.; SILVA, R.S.; SILVA, S.R.M.; FIGUEIREDO, G.A.B.G. Urbanismo e saneamento urbano sustentáveis: desenvolvimento de métodos para análise e avaliação de projetos. Segundo relatório: revisão bibliográfica. São Carlos: Patrocínio de Pesquisa CEF/UFSCar, 1999.

- THE WORLD COMMISSION ON ENVIRONMENT AND DEVELOPMENT. Our Commom Future, Oxford, Oxford University Press, 1987. 
- TIAGO FILHO, G.L. Perspectivas das PCHs face ao novo quadro institucional do Brasil. Centro Nacional de Referência em Pequenos Aproveitamentos Hidroenergéticos (CERPCH). Ano 1 N. ${ }^{\circ 3}$ Jun/Jul/Ago/99.

- TUNDISI, J.G. Limnologia e manejo de represas. Série: Monografias em Limnologia, vol.1. Academia de Ciências, 1988.

- VAINER, C.B. Grandes projetos e organização territorial: Os avatares do planejamento regional. In: MARGULIS, S. (ed.); LA ROVERE,E.L.; GALVÃO, J.B.; SILVEIRA, S.S.B.; SANT'ANNA, F.S.P.; MAGRINI, A.; MOTTA, R.S. da; VAINER, C.B.; TAUK, S.; SALATI, E. Meio ambiente aspectos técnicos e econômicos. Brasília. IPEA, 1990.

- VALENCIO, N.F.L.S.; GONÇALVES, J.C.; MARTINS, R.C.; LEME, A.A. Análise das alterações de comportamento do mercado de terras rural provocadas pela implantação de megaprojetos hídricos. In: CONGRESSO INTERNACIONAL DOS AMERICANISTAS, 50․, 2000, Varsóvia. Anais. Julho, 25p.

- VALENCIO, N.F.L.S.; GONÇALVES, J.C.; MARTINS, R.C.; LEME, A.A. Grandes projetos hídricos no Estado de São Paulo: análise comparativa dos padrões de desenvolvimento das áreas de influência direta dos reservatórios de Barra Bonita e Jurumirim. Relatório de pesquisa FAPESP/CNPq. São Carlos: UFSCar, 1998. 
- VIOLA, E. J. O movimento ambientalista no Brasil (1971-1991): da denúncia e conscientização pública para a institucionalização e o desenvolvimento sustentável. In: VIOLA, E.J.; ROVERE, E.L.; SADER.E.; FUKS, M.;HERCULANO, S. BOTELHO, V.L. Ecologica, ciência e política. Revan, 1992.

- VIOLA, E.J.; LEIS, H.R. A evolução das Políticas ambientais no Brasil, 1971 - 1991: do bissetorialismo preservacionista para o multissetorialismo orientado para o desenvolvimento sustentável. In: HOGAN, D.; VIEIRA, P.F. (orgs.). Dilemas sócio-ambientais e desenvolvimento sustentável. Campinas: Unicamp, 1992.

- VIOLA, E.J.; LEIS, H.R. O ambientalismo multissetorial no Brasil para além da Rio-92: o desafio de uma estratégia globalista viável. In: VIOLA, E.J.; LEIS, H.R.; SHERER-WARREN, I.; GUIVANT, J.S.; VIEIRA, P.F. e KRISHCKE, P.J. (orgs.). Meio Ambiente, desenvolvimento e cidadania: desafios para as Ciências Sociais. Cortez e UFSC, 1995.

- WIEGRATZ, W. Eficiência Energética. Gás de alto - forno utilizado na geração de energia, na CST, corresponde a 15mil barris diários de petróleo. In: Metalurgia \& Materiais. ABM. vol.59 - n.o 535 - Julho de 2003 pág. 376 e 377 . 
- ZYLBERSZTAJN, D. Pseudo-sabichão. Instituto de Desenvolvimento Estratégico do Setor Energético (ILUMINA). Banco de Dados. (http://wnw.ilumina.org.br). Acesso: 01/04/2004. 
ANEXO 01

(dados da CPFL, 2001)

\section{1 - Características da Bacia Hidrográfica}

Quanto a sua forma, possui fator de forma $k f=0,058$, sendo este coeficiente um parâmetro para avaliar a maior ou menor possibilidade de ocorrência de enchentes na bacia. No caso da bacia do rio Sapucaí, ela não é sujeita a grandes enchentes, pois o limite para tal é da ordem de $\mathrm{kf}=0,5$.

A densidade de drenagem da bacia, que mede a eficiência do sistema de drenagem da mesma é considerada boa, e varia com o inverso da extensão do escoamento superficial, que para a bacia do Sapucaí vale es = $4,87 \mathrm{~km}$.

A sinuosidade do rio Sapucaí vale $\sin =1,77$, que indica uma tendência para escoamentos não muito velozes.

A declividade média do rio Sapucaí é So $=0,097 \%$, com altitudes variando de $725 \mathrm{~m}$, na sua nascente, até cerca de $465 \mathrm{~m}$, na confluência com o rio Grande.

Quanto ao uso atual das terras, predomina-se o cultivo de milho, algodão, cana-de-açúcar, soja e outras culturas de caráter anual.

\section{2 - Climatologia da Bacia}

De acordo com a classificação de Köeppen, a bacia do rio Sapucaí apresenta climas do tipo Aw para a parte mais baixa e Cwa para a parte mais alta, com pontos isolados do tipo Cwb, conforme descritos a seguir: 
- Aw: clima tropical quente e úmido, com estação seca de outono-inverno, cerca de 80 à $90 \%$ de chuvas no período outubro à março, temperatura média variando de $24,7^{\circ} \mathrm{C}$ à $21,4^{\circ} \mathrm{C}$ e amplitude térmica superior à $5^{\circ} \mathrm{C}$.

- Cwa: clima mesotérmico, com verões quentes e inverno seco, atingindo regiões com altitudes entre 300,00 e 700,00m, temperatura média anual variando de $21,8^{\circ} \mathrm{C}$ à $19,5^{\circ} \mathrm{C}$.

- Cwb: clima mesotérmico com verões brandos e estação chuvosa no verão, abrangendo a região das serras, com temperatura média anual variando de $19,8^{\circ} \mathrm{C}$ à $17,4^{\circ} \mathrm{C}$.

A bacia recebe influência das perturbações extra-tropicais e dos sistemas tropicais. As perturbações extratropicais que atingem a região são representadas, principalmente, pelas incursões de massas de ar frio, provenientes do sul do continente americano. As perturbações tropicais são representadas pelos sistemas convectivos oriundos dos contrastes térmicos sobre o continente.

\section{Precipitação}

A distribuição sazonal das chuvas mostra uma nítida caracterização entre o periodo chuvoso (outubro à março) e o período seco (abril à setembro). O período chuvoso contribui com mais de $80 \%$ do total anual. O trimestre mais chuvoso é dezembro, janeiro e fevereiro, com índice superior a $200 \mathrm{~mm}$.

As precipitações máximas em 24 horas são da ordem de $127 \mathrm{~mm}$, e ocorrem com maior freqüência no mês de dezembro. 


\section{Umidade Relativa do $\mathrm{Ar}$}

Observa-se que os níveis de umidade na bacia são normais, com indices variando de 55 à $81 \%$.

\section{3 - Geologia Regional}

A geologia da região da bacia hidrográfica do rio Sapucaí faz parte da Bacia do Paraná, onde é representada por rochas da Série São Bento, apenas um pequeno trecho correspondente às nascentes do ribeirão Pinheirinho encontra-se em terrenos do complexo cristalino de idade précambriana.

1. Série São Bento

A Série São Bento se caracteriza por uma sucessão de camadas rochosas sub-horizontais que se alternam estratigraficamente:

- Arenito Botucatu;

- Eruptivas Básicas.

a.1) Arenito Botucatu

Tendo por base os inúmeros autores, além das características litológicas e estruturas sedimentares fornecidas através de observações geológicas de superfície, Barros et alli (1982) aceitaram para a Formação Botucatu um ambiente de deposição desérticas, sob clima árido e semiárido, com sedimentação tipicamente eólica nas porções mais superiores, mostrando nas partes basais depósitos com contribuições fluviais. Corrobora com as explanações acima o fato de ser observado, muitas vezes no campo, o microponteamento que ocorre em grãos médios reafirmando a 
idéia de transporte eólico sujeito a constantes choques e impactos entre os grãos.

\section{a.2) Formação Serra Geral}

A unidade em questão encontra-se recobrindo uma área significativa, que se estenderia desde o planalto ocidental do rio Piracicaba, no Estado de São Paulo, até a República do Uruguai. A idade geológica dessas rochas, segundo Derby (1878), seria certamente posterior ao Devoniano e muito provavelmente Mesozóica. White (1908) ao estudar os carvões do sudoeste catarinense utilizou pela primeira vez, a denominação de "Eruptivas da Serra Geral", para designar os derrames de lavas basálticas que ocorrem na serra homônima. Guidicini (1979) discutiu a gênese das feições internas de derrames basálticos. Szubert (1979) apresentou um esquema interpretativo da evolução geológica das rochas vulcânicas mesozóicas da Bacia do Paraná, propondo um modelo petrogenético em intima correlação com a evolução vulcanoestrutural das seqüências vulcânicas: segundo apresentado por esse autor, este uma perfeita consonância entre a evolução vulcânica progressiva e a evolução petrográfica possivelmente contínua.

Deste modo, os basaltos corresponderiam ao estágio inicial fissural e os termos intermediários, bem como as lavas ricas em sílica, respectivamente, aos estágios de vulcanismo de escudo e dômico final. Trabalhos mais recentes caracterizam a Formação Serra Geral como constituída de basaltos cinza-escuro, de granulometria fina a afanítica, 
localmente apresentando níveis de arenitos intertrapeanos, ocorrendo em grande extensão.

A Formação Serra Geral, que representa a parte superior do Grupo São Bento, na área de interesse mostra ocorrência significativa, constituindo-se na unidade de maior expressão areal. A espessura dessa Formação é muito variada chegando a alcançar 1025m em 13 derrames na seção Tainhas e Três Forquilhas, sendo comuns próximo as bordas da bacia espessuras que variam de 20 a $150 \mathrm{~m}$.

A espessura dos derrames normalmente não ultrapassam a $50 \mathrm{~m}$ sendo, no entanto, conhecidos valores de até $130 \mathrm{~m}$. O padrão de drenagem é retangular, quase sempre controlado por fraturas e falhas, aparecendo nos leitos dos principais rios que ocorrem na área estudada inúmeras cachoeiras e corredeiras. Essas rochas, quando alteradas, formam um solo argiloso e avermelhado típico com desenvolvimento de uma vegetação de grande porte, tipo mata, de muito uso na agricultura.

A Formação Serra Geral na região em questão se faz representar por lavas basálticas de natureza toleítica, com aspecto maciço, uniforme, amigdaloidal, vesiculares, contendo fraturas irregulares a subconchoidais, formando espessuras variáveis de derrames, com intercalações lenticulares e diques de arenitos. Litologicamente, as exposições dos derrames basálticos são constituídas por rochas de cores escuras a cinza-escuro, localmente vítreas, granulação fina à média, afanítica, ocasionalmente porfiritica; quando alterado superficialmente adquirem coloração amarelada, com amigdalas preenchidas por quartzo, calcita ou mineral esverdeado 
denominado nontronita. A disjunção colunar, estrutura típica de derrames espessos, ocorre também em corpos intrusivos, ocupando uma posição aproximadamente média à alta na sucessão dos derrames, quando costumam por vezes mostrar diaclasamentos em formas poligonais.

b) Terciário/Quaternário

\section{b.1) Cobertura Coluvionar}

Esta unidade de idade supostamente terciária/quaternária, corresponde a uma superfície desenvolvida a partir de um processo alteração e aplainamento. É caracterizada por latossolos vermelhos amarronzados, estrutura indefinida e textura argilo-silto-arenosa, com presença de óxido e hidróxidos de ferro e subordinadamente caolinita, apresentando perfis "maduros" e "imaturos", onde ocorrem níveis de "GM", ("granular material") com espessuras irregulares.

\section{b.2) Aluvião}

Constituem depósitos caracterizados por sedimentos inconsolidados, arenosos, representados por areias e lentes de material silto-argiloso. Distribuem-se, principalmente, nas planícies de inundação e ao longo das drenagens de maior porte, em alguns trechos do rio formando ilhas.

\section{4 - Descricão Geral dos Aproveitamentos}

4.1 - USINA ANHANGUERA

\section{Dados Gerais de Projeto}

N.A. máximo maximorum de operação a montante $(\mathrm{m})$ 540,50

N.A. máximo normal de operação a montante $(\mathrm{m})$ 540,50 
N.A. máximo normal de jusante $(\mathrm{m})$ 523,10

N.A. máximo maximorum de jusante $(\mathrm{m})$ 525,80

Área do reservatório no N.A. máximo normal $\left(\mathrm{km}^{2}\right)$...............................2,00

Volume acumulado total $\left(\mathrm{hm}^{3}\right)$ 12,00

Queda nominal (m) 17,16

Queda bruta (m) 17,4

Descarga média de longo termo $\left(\mathrm{m}^{3} / \mathrm{s}\right)$ 81,35

Vazão de projeto do vertedouro (TR $=10.000$ anos) $\left(\mathrm{m}^{3} / \mathrm{s}\right)$ 1.112

Vazão de projeto de desvio - $1^{\mathrm{a}}$ fase

$\mathrm{TR}=25$ anos - período completo $\left(\mathrm{m}^{3} / \mathrm{s}\right)$ 511

Vazão de projeto de desvio $-2^{\mathrm{a}}$ fase

$\mathrm{TR}=25$ anos - período estiagem $\left(\mathrm{m}^{3} / \mathrm{s}\right)$ 214

Energia firme - (MW médio) 8,91

Energia média - (MW médio) 10,60

Potência total instalada (MW) 18,50

As características gerais do aproveitamento, com potência instalada de 18,5MW e reservatório com área total inferior a $3,0 \mathrm{~km}^{2}$, enquadram-na como Pequena Central Hidrelétrica.

\section{Área de drenagem}

A bacia do rio Sapucaí drena uma área total de $6.570 \mathrm{~km}^{2}$, dos quais $4.654 \mathrm{~km}^{2}$ localizam-se a montante do barramento da PCH Anhangüera.

\section{Vazões Médias Mensais}


Para obtenção das séries de vazões médias mensais no local do aproveitamento, a metodologia consistiu no estabelecimento de correlação com o posto Pioneiros, tendo como parâmetro as áreas de drenagem.

A série de vazões médias mensais do posto Pioneiros, disponível de 1945 à 1970, foi estendida, por área de drenagem, a partir das séries dos postos Fazenda Velha (1931 à 1944), Santa Fé (1971 à 1981) e São Domingos (1982 à 1997). No período de 1998 à 1999, a série foi então estendida com as próprias médias mensais do período de 1931 à 1997.

\section{Disponibilidade de Dados Fluviométricos}

\begin{tabular}{|l|l|l|l|l|l|l|}
\hline Código & Nome & Rio & Entidade & $\begin{array}{l}\text { Adrenagem } \\
\left(\mathrm{km}^{2}\right)\end{array}$ & Início & Fim \\
\hline 61780500 & Fazenda Velha & Sapucai-Mirim & DAEE-SP & 3.863 & 1929 & 1946 \\
\hline 61783500 & Santa Fé & Sapucai-Mirim & DAEE-SP & 4.744 & 1971 & 1981 \\
\hline 61784000 & Pioneiros & Sapucai-Mirim & DAEE-SP & 4.748 & 1944 & 1970 \\
\hline 61787500 & Fazenda São Domingos & Sapucai-Mirim & DAEE-SP & 6.281 & 1969 & 1997 \\
\hline
\end{tabular}

Fonte: CPFL - Companhia Paulista de Força e Luz - PCH Anhanguera /

Relatório Final do Projeto Básico (08/janeiro/2001).

Local: PCH Anhangüera UF: SP Drenagem: $4.654 \mathrm{~km}^{2}$

Rio: $\quad$ Sapucai

\begin{tabular}{|l|l|l|l|l|l|l|l|l|l|l|l|l|l|}
\hline ANO & JAN & FEV & MAR & ABR & MAI & JUN & JUL & AGO & SET & OUT & NOV & DEZ & MÉDIA \\
\hline \hline 1997 & 252,45 & 201,72 & 161,97 & 109,73 & 87,01 & 88,11 & 59,04 & 43,96 & 36,17 & 36,04 & 47,50 & 93,04 & 101,39 \\
1998 & 125,33 & 145,02 & 137,88 & 107,48 & 79,27 & 63,44 & 50,71 & 40,30 & 36,95 & 42,31 & 58,34 & 85,08 & 81,01 \\
1999 & 125,33 & 145,02 & 137,88 & 107,48 & 79,27 & 63,44 & 50,71 & 40,30 & 36,95 & 42,31 & 58,34 & 85,08 & 81,01 \\
\hline \hline MED & 125,32 & 147,12 & 139,88 & 107,48 & 79,27 & 63,44 & 50,71 & 40,30 & 36,95 & 42,31 & 58,34 & 85,08 & 81,35 \\
MAX & 252,45 & 324,45 & 263,05 & 235,11 & 141,51 & 162,35 & 107,49 & 80,53 & 99,96 & 127,44 & 224,93 & 202,08 & 185,11 \\
MINI & 38,71 & 49,53 & 49,15 & 33,12 & 22,93 & 26,59 & 19,37 & 16,69 & 13,94 & 21,02 & 23,93 & 17,85 & 27,74 \\
\hline
\end{tabular}

Fonte: Adaptado de Série de Vazões Médias Mensais da PCH Anhangüera

- Relatório Final do Projeto Básico (CPFL, 2001). 


\section{$\underline{\text { Reservatório }}$}

O reservatório na cota do nível d'água normal possui volume de 1,20 x $10^{7} \mathrm{~m}^{3}$, tratando-se, portanto, de um reservatório de pequeno porte.

\section{Estudos de Remanso}

Para a PCH Anhanguera, estes visaram a verificação das condições do nível d'água sob a ponte da via Anhanguera, a qual não será atingida nem para a vazão centenária, nem para a vazão decamilenar.

\section{Vertedouro e Dissipação de Energia}

A existência de cachoeira pouco à jusante do local de implantação do vertedouro não dá garantia de formação de ressalto com características hidráulicas satisfatórias para uma gama variada de vazões. Independente da extensão adotada para a bacia, uma parcela ponderável do escoamento efluente da estrutura, após ultrapassar seu "end sill" com a energia potencial recuperada, acabará se encaminhando para o canal de fuga da usina, com repercussões indesejáveis, tais como elevação do nível d'água deste e/ou geração de ondas.

Uma solução seria o direcionamento intencional (canal de restituição) do fluxo do vertedouro para o braço esquerdo do rio, pelo menos para as vazões de vertimento mais freqüentes, o qual poderá reduzir as repercussões sobre o canal de fuga, inclusive minimizando o volume das escavações obrigatórias do mesmo.

\section{Escada para Transposição de Peixes}

A estrutura da escada para transposição de peixes será independente das demais e tem sua implantação prevista ao longo da margem direira. 
O início da escada está localizado logo à jusante da saida do canal de fuga, onde as vazões turbinadas garantem a atração dos peixes para esta região. Seu término está localizado à montante da barragem, já no reservatório. O controle da vazão será feito por comporta, com controle pela própria crista da barragem. A estrutura da escada é composta por degraustanque, com largura e comprimento iguais à $3,0 \mathrm{~m}$ e altura de $2,30 \mathrm{~m}$. Os tanques são formados por diques (anteparos de concreto) com 1,0m de altura e aberturas superiores e inferiores variando alternadamente a cada dique, de forma a permitir um espaço de remanso dentro de cada tanque.

Natureza Geológica e Geotécnica; melhor divisão de queda, condicionamento geológico-geotécnico e constrangimentos ambientais

A topografia do relevo é suave, onde predomina vale amplo e pouco acidentado. Para tal, o arranjo proposto a partir da ombreira é constituído por uma barragem de terra, atravessada por uma escada de peixe, seguida de um muro de encontro, tomada d'água e casa de força, essas últimas se estendendo até o leito do rio.

Devido ao pequeno capeamento do solo, todas as obras ficarão assentes sobre rocha, sendo previsto a remoção do primeiro metro superficial.

Ocorrendo zonas francamente permeáveis, as mesmas deverão ser objeto de análise para a tomada de decisão quanto aos tratamentos a serem adotados. 


\section{Leito do rio}

De modo geral, as fundações säo adequadas ao assentamento de obras de concreto e terra. Para as obras de concreto basta a limpeza dos aluviões aond€ eles ocorrem e a remoção dos materiais soltos. Após a limpeza deverá ser feita a regularização da superfície remanescente, abatendo-se os taludes negativos e fazendo-se o preenchimento com concreto dental das cavidades.

\section{$\underline{\text { Recomendações }}$}

Pode-se considerar que o local escolhido não apresenta nenhum fator de caráter geológico-geotécnico que comprometam o empreendimento. Por se tratar de fundações em basalto, aspectos ligados à presença de "juntas falhas" deverão ser observados, no sentido de se detectar e tratar essas estruturas quando as mesmas ocorrem a pequenas profundidades. A presença de jazidas de areias na região do empreendimento deverá ser pesquisada, uma vez que esses materiais säo os de maior dificuldade de obtenção tanto em volumes como em características, normalmente a granulometria é demasiadamente fina.

\section{Estudos Energéticos}

Potência Total $20 \mathrm{MW}$

Energia Média 10,63MW médio NA montante $540,50 m$

NA jusante médio $523,00 m$

Perdas no circuito de geração $2 \%$

Rendimento do conjunto turbina-gerador 0,882 
Queda de referência $16,70 \mathrm{~m}$

Tipo de operação Fio d'água (o volume do reservatório permitirá uma flexibilização diária ou semanal)

Conjuntos turbina-gerador 2 Tipo de turbina Tubular "S" (Kaplan "S") montante eixo horizontal com multiplicador de velocidade; responsável pela elevação da rotação de 180 para 600rpm, localizado entre a turbina e o gerador.

Potências serão calculadas levando-se em conta a existência de um multiplicador de velocidade.

\section{Caracterização ambiental}

A paisagem dominante na região do empreendimento compõe-se de um amplo mosaico que alterna cultura de soja e cana-de-açúcar, atravessadas por estreitas matas ciliares.

$\underline{\text { Clima }}$

Isotermas médias anuais de 12 à $22 \mathrm{C}$.

\section{Geologia}

A bacia hidrográfica do rio Sapucaí-Mirim situa-se geologicamente na borda nordeste da Bacia do Paraná que ocupa, no Brasil, segundo estudos de Águas Subterrâneas (DNAEE, 1974), uma área de cerca de um milhão de $\mathrm{km}^{2}$, estendo-se ainda pelo Paraguai, Uruguai e Argentina.

No território nacional abrange parte de Goiás, Minas Gerais e grandes áreas dos estados de Mato Grosso, São Paulo, Paraná, Santa Catarina e Rio Grande do Sul. Esta bacia tem seu eixo dado pelo Rio Paraná, que a divide quase simetricamente. 
As unidades litoestratigráficas representativas da bacia hidrográfica do rio Sapucaí-Mirim, no Estado de São Paulo, correspondem aos depósitos Aluvionares Continentais Indiferenciados Holocênicos, depósitos Sedimentares Correlatos à Formação Itaqueri supra-basálticos, cobrindo um intervalo de tempo que se estende, possivelmente, do Cretáceo Superior ao Holoceno, e a seqüência Vulcano-Sedimentar do Grupo São Bento da Bacia do Paraná, com importantes Intrusões Básicas Tubulares, datadas do Mesozóico (IPT, 1981).

Dentro da referida bacia hidrográfica predominam rochas do Grupo São Bento, representadas pelas formações Pirambóia, Botucatu e Serral Geral.

\section{$\underline{\text { Geomorfologia }}$}

As unidades do relevo do Estado de São Paulo que compõem a paisagem da bacia hidrográfica do rio Sapucaí-Mirim podem ser divididas, segundo aspectos de relevo, altitude, orientação das formas topográficas e processos de sedimentação e erosão, em duas grandes províncias, conforme IPT (1981), em: Cuestas Basálticas e Planalto Ocidental.

As declividades predominantes estão em torno de 12 à $20 \%$, podendo em alguns locais atingir até valores de 20 à $40 \%$. A erosão laminar do tipo severa à muito severa, desenvolve sulcos freqüentes de profundidade média.

\section{Pedologia}

Conforme Carta de Solos do Estado de São Paulo (CNEPA, 1960), a área da bacia hidrográfica do rio Sapucaí-Mirim no Estado de São Paulo 
engloba basicamente cinco unidades de solos, quais sejam: Litossolo Roxo (76\%), Latossolo Vermelho-Amarelo - fase arenosa (15\%), Litólico - fase substrato basáltico (3\%), Regossolo (5\%) e Hidromórficos (1\%).

\section{Recursos Hídricos}

A bacia do Sapucaí-Mirim drena uma área total de $650 \mathrm{~km}^{2}$. O comprimento total do rio Sapucaí-Mirim foz-nascente é de $337 \mathrm{~km}$.

Os principais afluentes são o ribeirão do Jardim, pela margem esquerda, e os ribeirões Sete Lagoas, do Estiva, Salgados, Santa Bárbara e Fortaleza, pela margem direita.

Nestas bacias o uso do solo é predominantemente agricola, ocupando $52,1 \%$ do total de área na bacia, com destaque para o café, a soja, o milho e a cana-de-açúcar, seguindo a pastagem com $34,1 \%$.

As indústrias predominantes são as de couro, particularmente, curtumes, além da indústria de laticínios.

A qualidade da água é acompanhada por 2 pontos de amostragem:

BA 4002 - Ribeirão dos Bagres, sob a ponte na Rodovia Municipal que liga SP -334 à Restinga

SP 2100 - Rio Sapucaí-Mirim, sob a ponte na Rodovia FrancaBarretos.

O rio Sapucai- Mirim é classificado pela Resolução n. ${ }^{\circ} 20$ do CONAMA como classe 2, ou seja, é um corpo cujas águas destacam-se:

- ao abastecimento doméstico, após tratamento convencional;

- à proteção das comunidades aquáticas;

- à recreação de contato primário (esqui-aquático, natação e mergulho); 
- à irrigação de hortaliças e plantas frutiferas;

- à criação natural e/ou intensiva (agricultura) de espécies destinadas à alimentação humana.

\section{Agricultura}

Bastante desenvolvida

\section{Uso e Ocupação do Solo e Cobertura Vegetal}

A ocupação do solo da região é dominada pela cultura canavieira, evidenciando-se sérios problemas de erosão em diversas áreas. Este modelo de ocupação, compartilhado pelo aproveitamento para o plantio de soja e milho, teve como conseqüência a redução drástica da cobertura florestal original ao longo dos anos.

Os efeitos diretos das atividades agrícolas e do desenvolvimento são evidenciados pelo intenso processo de carreamento das partículas do solo e o conseqüente assoreamento dos córregos e rios (e, possivelmente, do futuro reservatório), diminuindo sua capacidade de armazenamento de água.

A área compreendida pela bacia do médio rio Sapucaí encontra-se sob o domínio da região fitoecológica da Savana (Cerrado), predominando áreas de tensão ecológica entre esta formação e a Floresta Estacional Semi-Decidual e áreas de agricultura cíclica.

As atividades agrícolas evidenciadas classificam-se em reflorestamentos homogêneos (predominando os gêneros Eucaliptus sp. e Pinus sp.), agricultura (predominando culturas de cana-de-açúcar, soja e 
sorgo) e áreas de pastagens, cobertas por gramineas forrageiras, comumente mantidas através da queima anual.

\section{Recomendações dos Aspectos Ambientais}

Em $1^{\circ}$ de Junho de 1994, a Secretaria de Estado do Meio Ambiente do Estado de São Paulo (SMA - SP) concedeu a Licença Prévia (LP), concedida com base no Parecer Técnico SMA n. ${ }^{\circ} 7.502 / 90$ e na Deliberação CONAMA 21/91, que aprovou os referidos aproveitamentos, apresentando, entretanto, um conjunto de exigências a serem cumpridas quando da solicitação da Licença de Instalação (LI) como:

- projeto executivo de reflorestamento ciliar;

- projeto de implantação do viveiro;

- levantamento detalhado da fauna;

- programa de reassentamento da fauna;

- programa de resgate da fauna nas fases de limpeza e enchimento dos reservatórios;

- programa de desinfecção de currais e tamponamento de poços.

\section{PCH - PALMEIRAS}

\section{Dados Gerais de Projeto}

N.A. máximo maximorum de operação a montante $(\mathrm{m})$ 556,00

N.A. máximo normal de operação a montante $(\mathrm{m})$. $.556,00$

N.A. máximo normal de jusante $(m)$. 542,73

N.A. máxima maximorum de jusante $(\mathrm{m})$ $.546,50$

Área do reservatório no N.A. máximo normal $\left(\mathrm{km}^{2}\right)$. 2,67 
Volume acumulado total $\left(\mathrm{hm}^{3}\right)$

Queda nominal (m)

Queda bruta (m)

Descarga média de longo termo $\left(\mathrm{m}^{3} / \mathrm{s}\right)$

Vazão de projeto do vertedouro (TR $=10.000$ anos) $\left(\mathrm{m}^{3} / \mathrm{s}\right)$

Vazão de projeto de desvio - $1^{\mathrm{a}}$ fase

$\mathrm{TR}=25$ anos - período completo $\left(\mathrm{m}^{3} / \mathrm{s}\right)$

Vazão do projeto de desvio $-2^{a}$ fase

$\mathrm{TR}=25$ anos - periodo de estiagem $\left(\mathrm{m}^{3} / \mathrm{s}\right)$

Energia firme - (MW médio)

Energia Média - (MW médio) 8,13

Potência total instalada (MW) 13,60

As caracteristicas gerais do aproveitamento, com potência instalada de $13,6 \mathrm{MW}$ e reservatório com área total inferior a $3,0 \mathrm{~km}^{2}$, enquadram-na como Pequena Central Hidrelétrica.

\section{$\underline{\text { Área de Drenagem }}$}

A bacia do rio Sapucai drena uma área total de $6.570 \mathrm{~km}^{2}$, dos quais $4.505 \mathrm{~km}^{2}$ localizam-se à montante do barramento da PCH Palmeiras.

\section{Vazões Médias Mensais}

Para obtenção das séries de vazões médias mensais no local do aproveitamento, a metodologia consistiu no estabelecimento de correlação com o posto Pioneiros, tendo como parâmetro as áreas de drenagem.

A série de vazões médias mensais do posto Pioneiros, disponível de 1945 à 1970, foi estendida, por área de drenagem, a partir das séries dos 
postos Fazenda Velha (1931 à 1944), Santa Fé (1971 à 1981) e São

Domingos (1982 à 1997). No periodo de 1998 à 1999, a série foi então estendida com as próprias médias mensais do período de 1931 à 1997.

Disponibilidade de Dados Fluviométricos

\begin{tabular}{|l|l|l|l|l|l|l|}
\hline Código & Nome & Rio & Entidade & $\begin{array}{l}\text { Adrenagem } \\
\left(\mathbf{k m}^{2}\right)\end{array}$ & Início & Fim \\
\hline 61780500 & Fazenda Velha & Sapucai-Mirim & DAEE-SP & 3.863 & 1929 & 1946 \\
\hline 61783500 & Santa Fé & Sapucai-Mirim & DAEE-SP & 4.744 & 1971 & 1981 \\
\hline 61784000 & Pioneiros & Sapucai-Mirim & DAEE-SP & 4.748 & 1944 & 1970 \\
\hline 61787500 & Fazenda São Domingos & Sapucai-Mirim & DAEE-SP & 6.281 & 1969 & 1997 \\
\hline
\end{tabular}

Fonte: CPFL - Companhia Paulista de Força e Luz - PCH Palmeiras /

Relatório Final do Projeto Básico (08/janeiro/2001).

Local: PCH Palmeiras

UF: $\quad$ SP

Drenagem: $\quad 4.504 \mathrm{~km}^{2}$

\begin{tabular}{|c|c|c|c|c|c|c|c|c|c|c|c|c|c|}
\hline ANO & JAN & FEB & MAR & APR & MAY & JUN & JUL & AUG & SEP & OCT & NOV & DEC & MÉDIA \\
\hline 1997 & 244,32 & 195,22 & 156,75 & 106,20 & 84,21 & 85,27 & 57,14 & 42,54 & 35,01 & 34,88 & 45,97 & 90,04 & 98,13 \\
\hline $\begin{array}{l}1998 \\
1999\end{array}$ & 121,29 & 140,35 & 133,44 & 104,01 & 76,71 & 61,39 & 49,08 & 39,00 & 35,76 & 40,95 & 56,46 & 82,33 & 78,40 \\
\hline 1999 & 121,29 & 140,35 & 133,44 & 104,01 & 76,71 & 61,39 & 49,08 & 39,00 & 35,76 & 40,95 & 56,46 & 82,33 & 78,40 \\
\hline 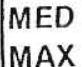 & & 142,38 & 135,37 & 104,01 & 76,71 & 61,39 & 49,08 & 39,00 & 35,76 & 40,95 & 56,46 & 82,33 & 78,73 \\
\hline & 244,32 & 314,00 & 254,57 & ,53 & 136,95 & 157,12 & 104,03 & 4 & 96,74 & 123,33 & 217,68 & 195,56 & 179,15 \\
\hline
\end{tabular}

\begin{tabular}{r|l|l|l|l|l|l|l|l|l|l|l|l|l|l|l} 
MINI & 37,47 & 47,93 & 47,57 & 32,05 & 22,19 & 25,73 & 18,75 & 16,15 & 13,49 & 20,34 & 23,16 & 17,27 \\
Fonte: Adaptado de Série de Vazões Médias Mensais da PCH Palmeiras -
\end{tabular}

Relatório Final do Projeto Básico (CPFL, 2001).

\section{Reservatório}

O reservatório na cota do nível d'água normal possui volume de 1,65 x $10^{7} \mathrm{~m}^{3}$, tratando-se, portanto, de um reservatório de pequeno porte.

\section{Escada para Transposição de Peixes}

A estrutura da escada para transposição de peixes será independente das demais e tem sua implantação prevista ao longo da margem esquerda.

O início da escada está localizado logo à jusante da saída do canal de fuga, onde as vazões turbinadas garantem a atração dos peixes para esta 
região. A estrutura da escada é composta por degraus-tanques, com largura e comprimento iguais a $3,0 \mathrm{~m}$ e altura de $2,30 \mathrm{~m}$. Os diques (anteparos de concreto), existentes entre cada degrau-tanque, deverão ter $1,0 \mathrm{~m}$ de altura. Alternadamente, nos cantos superiores de cada dique, terá um vão (rebaixo), com $0,80 \mathrm{~m}$ de comprimento e altura de $0,20 \mathrm{~m}$. Nos cantos inferiores de cada dique, também estão previstas uma passagem, com largura de 0,50m e altura de 0,40m, posicionadas de forma alternada.

Natureza Geológica e Geotécnica: melhor divisão de queda, condicionamento geológico-geotécnico e constrangimentos ambientais

Na região do eixo estudado a topografia apresenta um relevo suave, onde predomina vale amplo pouco acidentado onde são encontrados depósitos coluviais, solos residuais maduros e sapróllito de basaltos. Junto às margens são encontrados depósitos aluviais constituídos por areia fina, silte e argila.

A área de interesse está representada por rochas basálticas da Formação Serra Geral cobertas por solos aluvionares junto às margens e por solos coluvionares e residuais nas encostas. A rocha está aflorante apenas no leito do rio.

Investigações também revelaram que o maciço rochoso é composto por um conjunto de rochas e feiçőes associadas à derrames: basalto denso, basalto vesículo amigdaloidal, brecha basáltica arenosa e "junta falhas". 


\section{Leito do rio}

O leito do rio é constituído por um substrato rochoso basáltico adequado à fundação de obras terra, sendo no entanto, necessários alguns tratamentos relativos a impermeabilização do mesmo.

Como fundação de obras de concreto apresenta-se mais adequado na porção próximo à margem esquerda aonde a rocha sã está próxima a cota $538 \mathrm{~m}$. Próximo ao centro do rio em direção à margem oposta a rocha adequada à estruturas de concreto mergulha formando uma depressão atingindo na margem direita a cota $532 \mathrm{~m}$. Nesse trecho a partir da margem direita será implantada o restante da barragem de terra, seguido a essa serão implantadas as obras de concreto composta de um muro de ligação direito, vertedor, tomada d'água e casa de força e muro de ligação esquerdo.

Para essas estruturas deverão ser feita a limpeza e regularização da superfície remanescente, abatendo os talude negativos e fazendo-se o preenchimento com concreto dental das cavidades abaixo das estruturas de concreto e da porção à montante das estruturas drenantes da barragem de terra, abaixo dessas o preenchimento deverá ser feito com material drenante.

\section{$\underline{\text { Recomendações }}$}

Pode-se considerar que o local escolhido não apresenta nenhum fator de caráter geológico-geotécnico que comprometam o empreendimento. Por se tratar de fundações em basalto, aspectos ligados à presença de "juntas falhas" deverão ser observados, no sentido de se detectar e tratar essas 
estruturas quando as mesmas ocorrem a pequenas profundidades. A presença de jazidas de areias na região do empreendimento deverá ser pesquisada, uma vez que esses materiais são os de maior dificuldade de obtenção tanto em volumes como em características, normalmente a granulometria é demasiadamente fina.

\section{Estudos Energéticos}

Potência total $15,1 \mathrm{MW}$

Energia Média 8,16 MW médio

NA montante $556,00 \mathrm{~m}$

NA jusante médio $542,05 \mathrm{~m}$

Perdas no circuito de geração $2 \%$

Rendimento do conjunto turbina-gerador 0,89 Queda de referência $12,90 \mathrm{~m}$ Tipo de operação Fio d'água (o volume do reservatório permitirá uma flexibilização diária ou semanal)

Conjuntos turbina-gerador 2

Tipo de turbina Poço (Kaplan-poco) de eixo horizontal com multiplicador de velocidade de relação 170rpm na turbina para 720rpm no gerador.

Potências serão calculadas levando-se em conta a existência de um multiplicador de velocidade.

Caracterização ambiental - Idem PCH Anhanguera 


\section{Recomendações dos Aspectos Ambientais}

Da mesma forma como para a PCH Anhanguera, em $1^{\circ}$ de Junho de 1994, a Secretaria de Estado do Meio Ambiente do Estado de São Paulo (SMA - SP) concedeu a Licença Prévia (LP), concedida com base no Parecer Técnico SMA n. ${ }^{\circ}$ 7.502/90 e na Deliberação CONAMA 21/91, que aprovou os referidos aproveitamentos, apresentando, entretanto, um conjunto de exigências a serem cumpridas quando da solicitação da Licença de Instalação (LI) como:

- projeto executivo de reflorestamento ciliar;

- projeto de implantação do viveiro;

- levantamento detalhado da fauna;

- programa de reassentamento da fauna;

- programa de resgate da fauna nas fases de limpeza e enchimento dos reservatórios;

- programa de desinfecção de currais e tamponamento de poços.

\section{PCH - RETIRO}

\section{Dados Gerais de Projeto}

N.A. máximo maximorum de operação a montante $(\mathrm{m})$ $.523,00$

N.A. máximo normal de operação a montante $(m)$ 523,00

N.A. máximo normal de jusante $(\mathrm{m})$ 509,82

N.A. máximo mximorum de jusante $(m)$. 512,51

Área do reservatório no N.A. máximo normal $\left(\mathrm{km}^{2}\right)$. 3,13

Volume acumulado total $\left(\mathrm{hm}^{3}\right)$ $.16,46$ 
Queda nominal (m)

Queda bruta (m) 13,18

Descarga média de longo termo $\left(\mathrm{m}^{3} / \mathrm{s}\right)$ 82,28

Vazão de projeto do vertedouro (TR $=10.000$ anos) $\left(\mathrm{m}^{3} / \mathrm{s}\right)$. 1.124

Vazão de projeto de desvio - $1^{\mathrm{a}}$ fase

$\mathrm{TR}=25$ anos - periodo completo $\left(\mathrm{m}^{3} / \mathrm{s}\right)$. $.516,00$

Vazão de projeto de desvio $-2^{\mathrm{a}}$ fase

$\mathrm{TR}=25$ anos - periodo estiagem $\left(\mathrm{m}^{3} / \mathrm{s}\right)$ 216,00

Energia firme - (MW médio) 7,17

Energia média - (MW médio) 8,53

Potência total instalada (MW). 14,40

As características gerais do aproveitamento, com potência instalada de $14,4 \mathrm{MW}$ e reservatório com área total inferior a $3,0 \mathrm{~km}^{2}$, enquadram-na como Pequena Central Hidrelétrica.

\section{Área de Drenagem}

A bacia do rio Sapucaí drena uma área total de $6.570 \mathrm{~km}^{2}$, dos quais $4.707 \mathrm{~km}^{2}$ localizam-se à montante do barramento da PCH Retiro.

\section{Vazões Médias Mensais}

Para obtenção das séries de vazões médias mensais no local do aproveitamento, a metodologia consistiu no estabelecimento de correlação com o posto Pioneiros, tendo como parâmetro as áreas de drenagem.

A série de vazões médias mensais do posto Pioneiros, disponível de 1945 à 1970, foi estendida, por área de drenagem, a partir das séries dos postos Fazenda Velha (1931 à 1944), Santa Fé (1971 à 1981) e São 
Domingos (1982 à 1997). No periodo de 1998 à 1999, a série foi então

estendida com as próprias médias mensais do período de 1931 à 1997.

\section{Disponibilidade de Dados Fluviométricos}

\begin{tabular}{|l|l|l|l|l|l|l|}
\hline Código & Nome & Rio & Entidade & $\begin{array}{l}\text { Adrenagem } \\
\left(\mathrm{km}^{2}\right)\end{array}$ & Inicio & Fim \\
\hline 61780500 & Fazenda Velha & Sapucai-Mirim & DAEE-SP & 3.863 & 1929 & 1946 \\
\hline 61783500 & Santa Fé & Sapucai-Mirim & DAEE-SP & 4.744 & 1971 & 1981 \\
\hline 61784000 & Pioneiros & Sapucai-Mirim & DAEE-SP & 4.748 & 1944 & 1970 \\
\hline 61787500 & Fazenda São Domingos & Sapucai-Mirim & DAEE-SP & 6.281 & 1969 & 1997 \\
\hline
\end{tabular}

Fonte: CPFL - Companhia Paulista de Força e Luz - PCH Retiro / Relatório

Final do Projeto Básico (08/janeiro/2001).

Local: PCH Retiro

Rio: Sapucai
UF: $\quad S P$

Drenagem: $\quad 4.707$

\begin{tabular}{|l|l|l|l|l|l|l|l|l|l|l|l|l|l|}
\hline ANO & JAN & FEB & MAR & APR & MAY & JUN & JUL & AUG & SEP & OCT & NOV & DEC & MÉDIA \\
\hline \hline 1997 & 255,33 & 204,01 & 163,81 & 110,98 & 88,00 & 89,11 & 59,71 & 44,46 & 36,58 & 36,45 & 48,04 & 94,10 & 102,55 \\
1998 & 126,76 & 146,67 & 139,45 & 108,70 & 80,17 & 64,16 & 51,29 & 40,76 & 37,37 & 42,79 & 59,01 & 86,05 & 81,93 \\
1999 & 126,76 & 146,67 & 139,45 & 108,70 & 80,17 & 64,16 & 51,29 & 40,76 & 37,37 & 42,79 & 59,01 & 86,05 & 81,93 \\
\hline MEDIA & 126,75 & 148,80 & 141,47 & 108,70 & 80,17 & 64,16 & 51,29 & 40,76 & 37,37 & 42,79 & 59,01 & 86,05 & 82,28 \\
MAX & 255,33 & 328,15 & 266,04 & 237,79 & 143,12 & 164,20 & 108,71 & 81,45 & 101,10 & 128,89 & 227,49 & 204,38 & 187,22 \\
MINI & 39,16 & 50,09 & 49,71 & 33,49 & 23,20 & 26,89 & 19,59 & 16,88 & 14,10 & 21,26 & 24,20 & 18,05 & 28,05 \\
\hline
\end{tabular}

Fonte: Adaptado da Série de Vazões Médias Mensais da PCH Retiro -

Relatório Final do Projeto Básico (CPFL,2001).

\section{$\underline{\text { Reservatório }}$}

O reservatório na cota do nível d'água normal possui volume de $1,646 \times 10^{7} \mathrm{~m}^{3}$, tratando-se, portanto, de um reservatório de pequeno porte.

\section{Escada para Transposição de Peixes}

A estrutura da escada para transposição de peixes será independente das demais e tem sua implantação prevista ao longo da margem direita.

O início da escada está localizado logo à jusante da saída do canal de fuga, onde as vazões turbinadas garantem a atração dos peixes para esta região. A estrutura da escada é composta por degraus-tanques, com 
largura e comprimento iguais a $3,0 \mathrm{~m}$ e altura de $2,30 \mathrm{~m}$. Os diques (anteparos de concreto), existentes entre cada degrau-tanque, deverão ter $1,0 \mathrm{~m}$ de altura. Alternadamente, nos cantos superiores de cada dique, terá um vão (rebaixo), com 0,80 m de comprimento e altura de $0,20 \mathrm{~m}$. Nos cantos inferiores de cada dique, também estão previstas uma passagem, com largura de 0,50m e altura de 0,40m, posicionadas de forma alternada.

Natureza Geológica e Geotécnica; melhor divisão de queda, condicionamento geológico-geotécnico e constrangimentos ambientais

Na região do eixo estudado a topografia apresenta um relevo suave, onde predomina vale amplo pouco acidentado onde são encontrados depósitos coluviais, solos residuais maduros e sapróllito de basaltos. Junto às margens são encontrados depósitos aluviais constituídos por areia fina, silte e argila.

A área de interesse está representada por rochas basálticas da Formação Serra Geral cobertas por solos aluvionares junto às margens e por solos coluvionares e residuais nas encostas. A rocha está aflorante apenas no leito do rio.

Investigações também revelaram que o maciço rochoso é composto por um conjunto de rochas e feições associadas à derrames: basalto denso, basalto vesículo amigdaloidal, brecha basáltica arenosa e "junta falhas".

\section{Leito do rio}

O leito do rio é constituído por um substrato rochoso basáltico não fraturado à medianamente fraturado, em profundidade próximo à margem esquerda ocorrem basaltos vesiculares confinados lateralmente por basalto 
denso. Nesse trecho serão implantadas o restante das obras de concreto e encontro da barragem de terra da margem esquerda.

Para essas estruturas deverão ser feita a limpeza e regularização da superficie remanescente. Em subsuperficie para as obras em concreto será dada continuidade dos tratamentos iniciados na margem direita.

As obras de terra serão apoiadas sobre rocha, e nesse caso, a regularização da superfície remanescente no trecho à jusante do núcleo será feita através de materiais granulares.

\section{$\underline{\text { Recomendações }}$}

Pode-se considerar que o local escolhido não apresenta nenhum fator de caráter geológico-geotécnico que comprometam o empreendimento. Por se tratar de fundações em basalto, aspectos ligados a presença de "juntas falhas" deverão ser observados, no sentido de se detectar e tratar essas estruturas quando as mesmas ocorrem a pequenas profundidades. A presença de jazidas de areias na região do empreendimento deverá ser pesquisada, uma vez que esses materiais são os de maior dificuldade de obtenção tanto em volumes como em características, normalmente a granulometria é demasiadamente fina.

\section{Estudos Energéticos}

Potência total $15,1 \mathrm{MW}$

Energia Média 8,14 MW médio

NA montante $523,00 \mathrm{~m}$

NA jusante médio $509,49 m$

Perdas no circuito de geração $2 \%$ 
Rendimento do conjunto turbina-gerador 0,885

Queda de referência $12,70 \mathrm{~m}$

Tipo de operação Fio d'água (o volume do reservatório permitirá uma flexibilização diária ou semanal)

Conjuntos turbina-gerador 2

Tipo de turbina Poço (Kaplan-poço) de eixo horizontal com multiplicador de velocidade de relação 170rpm na turbina para 720rpm no gerador.

Potências serão calculadas levando-se em conta a existência de um multiplicador de velocidade.

Caracterização ambiental - Idem PCH Anhanguera

Recomendações dos Aspectos Ambientais

Da mesma forma como para a PCH Anhanguera, em $1^{\circ}$ de Junho de 1994, a Secretaria de Estado do Meio Ambiente do Estado de São Paulo (SMA - SP) concedeu a Licença Prévia (LP), concedida com base no Parecer Técnico SMA n. ${ }^{\circ} 7.502 / 90$ e na Deliberação CONAMA 21/91, que aprovou os referidos aproveitamentos, apresentando, entretanto, um conjunto de exigências a serem cumpridas quando da solicitação da Licença de Instalação (LI) como:

- projeto executivo de reflorestamento ciliar;

- projeto de implantação do viveiro;

- levantamento detalhado da fauna;

- programa de reassentamento da fauna; 
- programa de resgate da fauna nas fases de limpeza e enchimento dos reservatórios;

- programa de desinfecção de currais e tamponamento de poços. 